Santa Clara University

Scholar Commons

Environmental Studies and Sciences

College of Arts \& Sciences

$9-2009$

\title{
Synorogenic evolution of large-scale drainage patterns: Isotope paleohydrology of sequential Laramide basins
}

Steven J. Davis

Hari T.Mix

Santa Clara University,hmix@scu.edu

Bettina A. Wiegand

Alan R. Carroll

C. Page Chamberlain

Follow this and additional works at: http://scholarcommons.scu.edu/ess

Part of the Environmental Studies Commons

\section{Recommended Citation}

Davis, S.J., Mix, H.T., Wiegand, B.A., Carroll, A.R. and Chamberlain, C.P. (2009). Synorogenic evolution of large-scale drainage patterns: Isotope paleohydrology of sequential Laramide basins. American Journal of Science, v. 309, p. 549-602.

Reproduced by permission of the American Journal of Science.

DOI $10.2475 / 07.2009 .02$

This Article is brought to you for free and open access by the College of Arts \& Sciences at Scholar Commons. It has been accepted for inclusion in Environmental Studies and Sciences by an authorized administrator of Scholar Commons. For more information, please contact rscroggin@scu.edu. 


\title{
SYNOROGENIC EVOLUTION OF LARGE-SCALE DRAINAGE PATTERNS: ISOTOPE PALEOHYDROLOGY OF SEQUENTIAL LARAMIDE BASINS
}

\author{
STEVEN J. DAVIS ${ }^{*}$, HARI T. MIX**, BETTINA A. WIEGAND***, \\ ALAN R. CARROLL ${ }^{\S}$, and C. PAGE CHAMBERLAIN**
}

\begin{abstract}
In the past decade, we and others have compiled an extensive dataset of $\mathrm{O}, \mathrm{C}$ and $\mathrm{Sr}$ isotope stratigraphies from sedimentary basins throughout the Paleogene North American Cordillera. In this study, we present new results from the Piceance Creek Basin of northwest Colorado, which record the evolving hydrology of the Eocene Green River Lake system. We then place the new data in the context of the broader Cordilleran dataset and summarize implications for understanding the synorogenic evolution of large-scale drainage patterns. The combined data reflect (1) a period of throughgoing foreland rivers heading in the Sevier fold-and-thrust belt and flowing east, (2) ponding of freshwater lakes in the foredeep as Laramide uplifts blocked drainage, (3) hydrologic closure that led to both intensive evaporation in the terminal sink of the Piceance Creek Basin and integration of catchments over length-scales $>1000 \mathrm{~km},(4)$ infilling of basin accommodation by southward migrating magmatism in distal catchments, leading to the freshening and demise of intraforeland lakes that also stepped south over time.
\end{abstract}

Key words: Isotope ratios, North American Cordillera, Green River Lakes, Sevier fold-and-thrust belt, paleoaltimetry, limnogeology

\section{INTRODUCTION}

Synorogenic sediments preserved in intermontane and foreland basins have long been appreciated as valuable archives of orogen and basin development, recording the complex linkage among tectonics, climate and landscape evolution. As such, clastic basin fill has been exploited by many studies using tools of sedimentary petrology and provenance, paleocurrent analysis, and kinematic histories (for example, Dickinson and others, 1986, 1988; Lawton, 1986; DeCelles, 1988; DeCelles and others, 1995; Smith and others, 2008a). In the past decade, numerous isotopic studies have also demonstrated the potential of authigenic sediments in reconstructing surface elevation and climate (for example, Koch and others, 1995; Chamberlain and Poage, 2000; Garzione and others, 2000; Fricke, 2003; Graham and others, 2005; Kent-Corson and others, 2006).

Unfortunately, very few isotopic studies have assembled large, regional datasets capable of distinguishing local and regional signals in the geologic past, and even fewer have considered the effect of large-scale drainage reorganization on their results (Davis and others, 2008). Here we add data to the most spatially and temporally dense dataset in existence, totaling more than 3000 isotopic analyses in multiple isotope systems on samples collected from 12 basins spanning $\sim 1400 \mathrm{~km}$ along strike of the Tertiary North American Cordillera (table 1). Using this dataset, we summarize mounting isotopic evidence for the regional evolution of drainage patterns in both the hinterland and foreland of the orogen. Despite important changes in global climate during the Paleogene, we further conclude these regional changes in basin hydrology were driven by tectonic processes.

\footnotetext{
* Department of Global Ecology, Carnegie Institution of Washington, Stanford, California 94305, USA

** Environmental Earth System Science, Stanford University, Stanford, California 94305, USA; hmix@stanford.edu; chamb@stanford.edu

*** Geological and Environmental Sciences, Stanford University, Stanford, California 94305, USA; bwiegand@stanford.edu

\$ Department of Geology and Geophysics, University of Wisconsin, Madison, Wisconsin 53706, USA; acarroll@geology.wisc.edu

${ }^{\dagger}$ Corresponding author: sjdavis@stanford.edu
} 


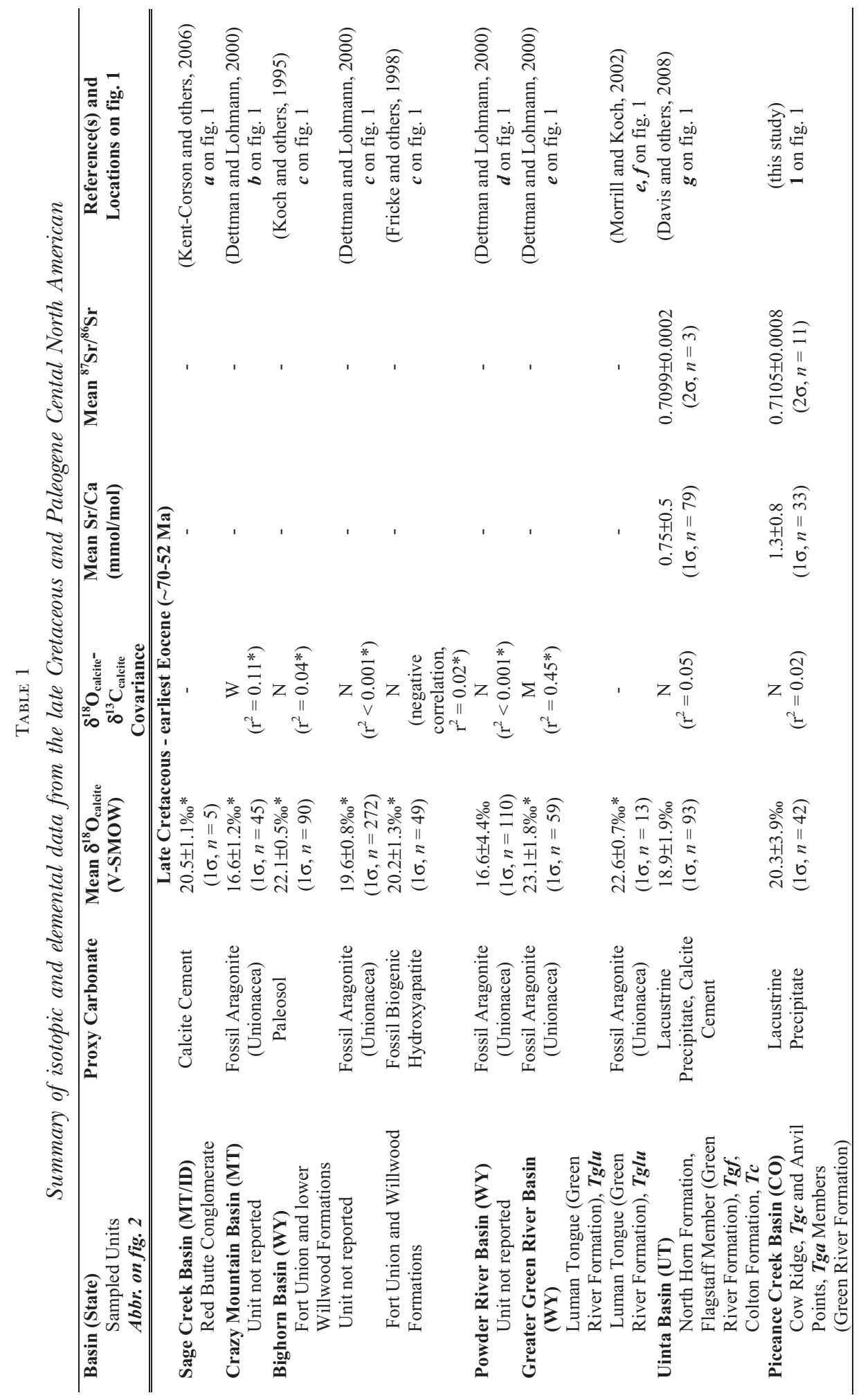


patterns: Isotope paleohydrology of sequential Laramide basins

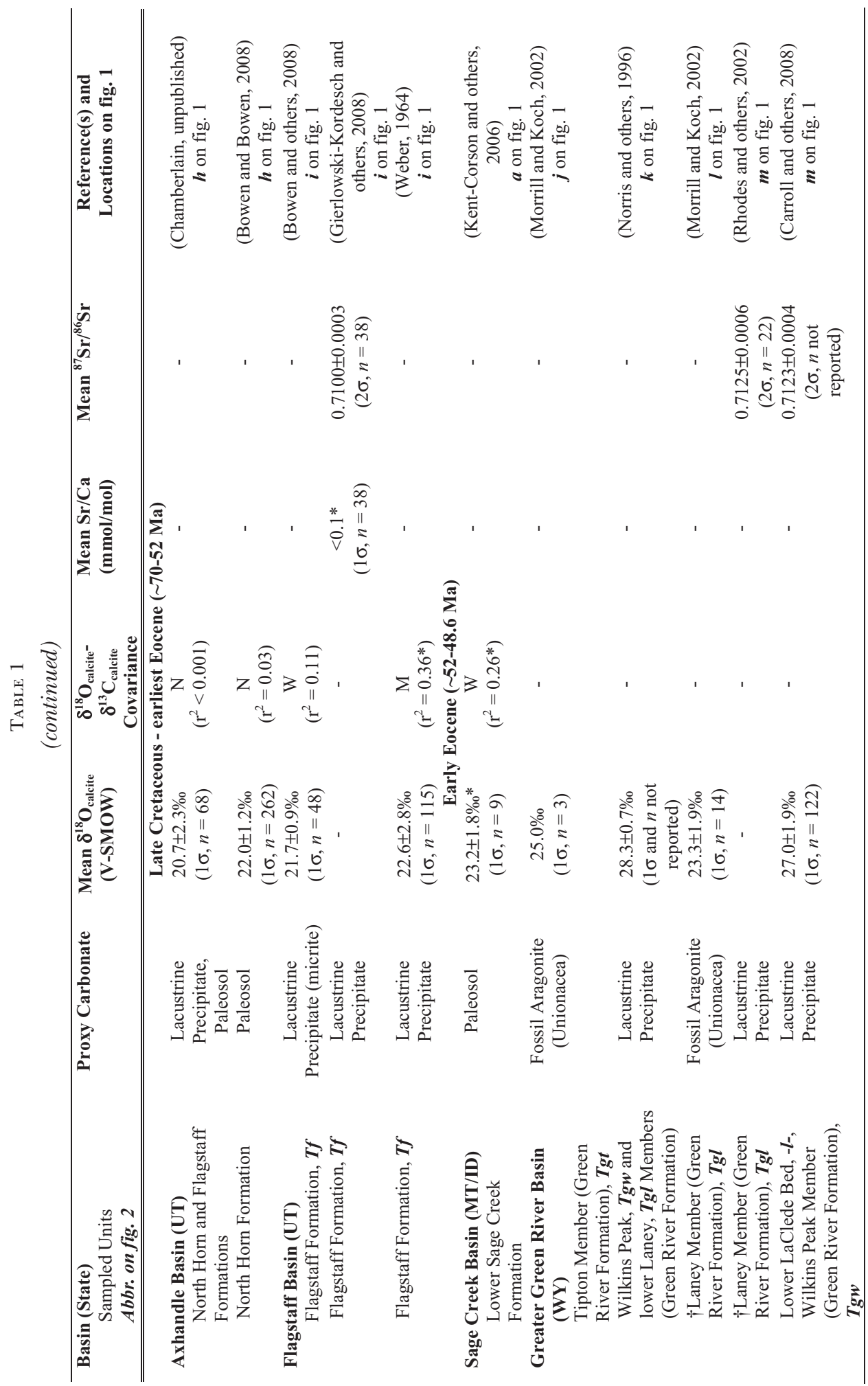




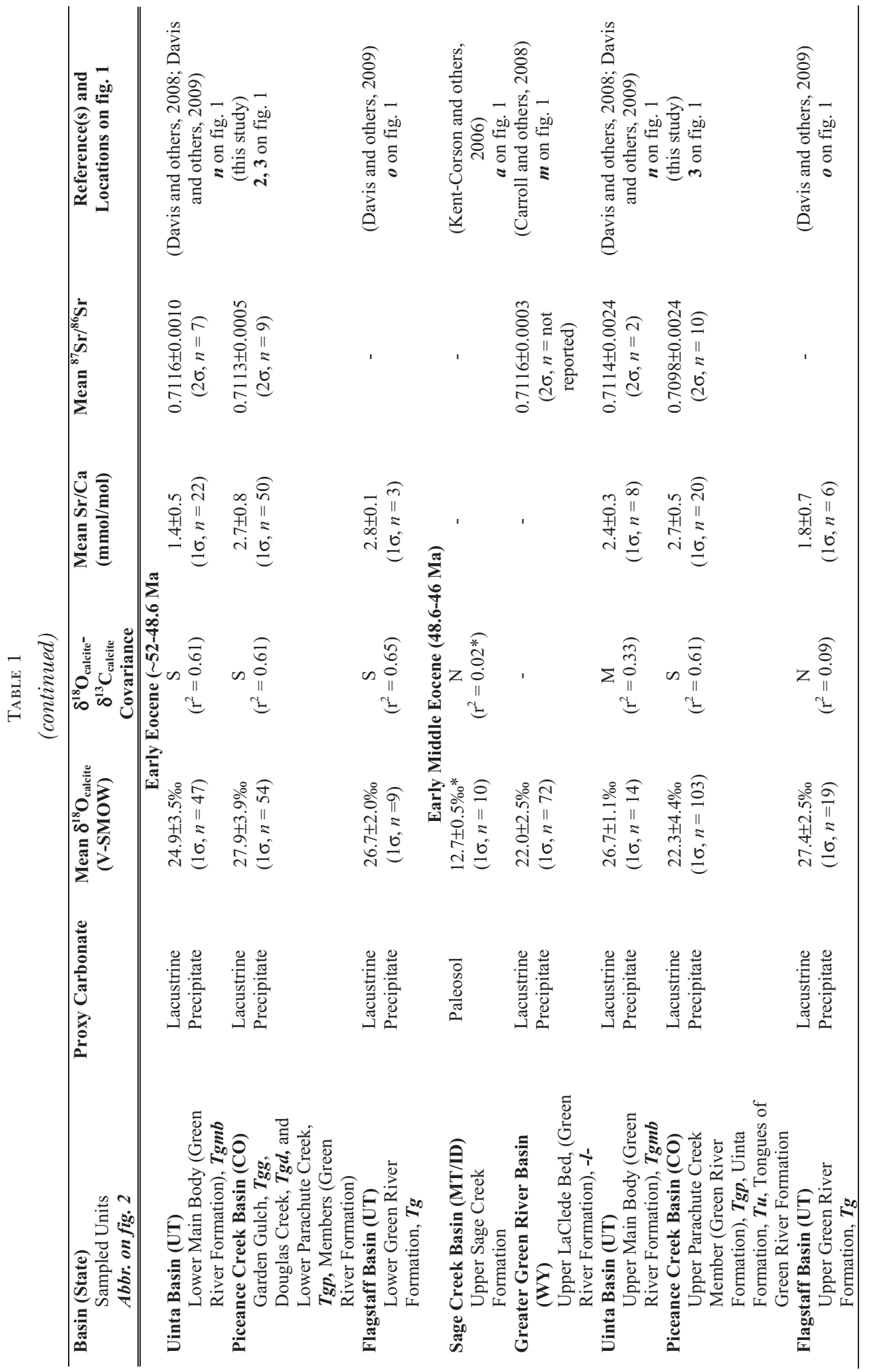


patterns: Isotope paleohydrology of sequential Laramide basins

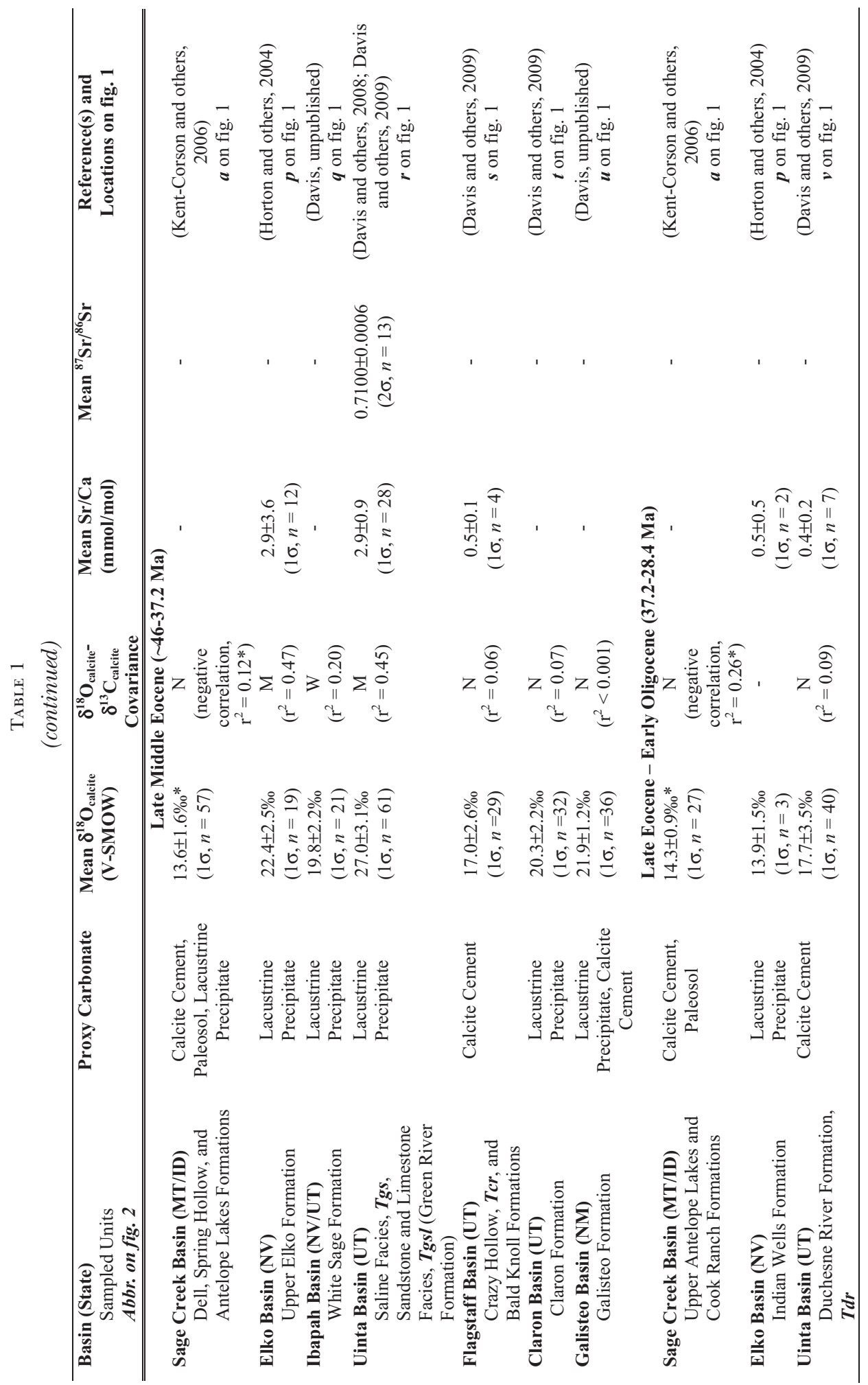




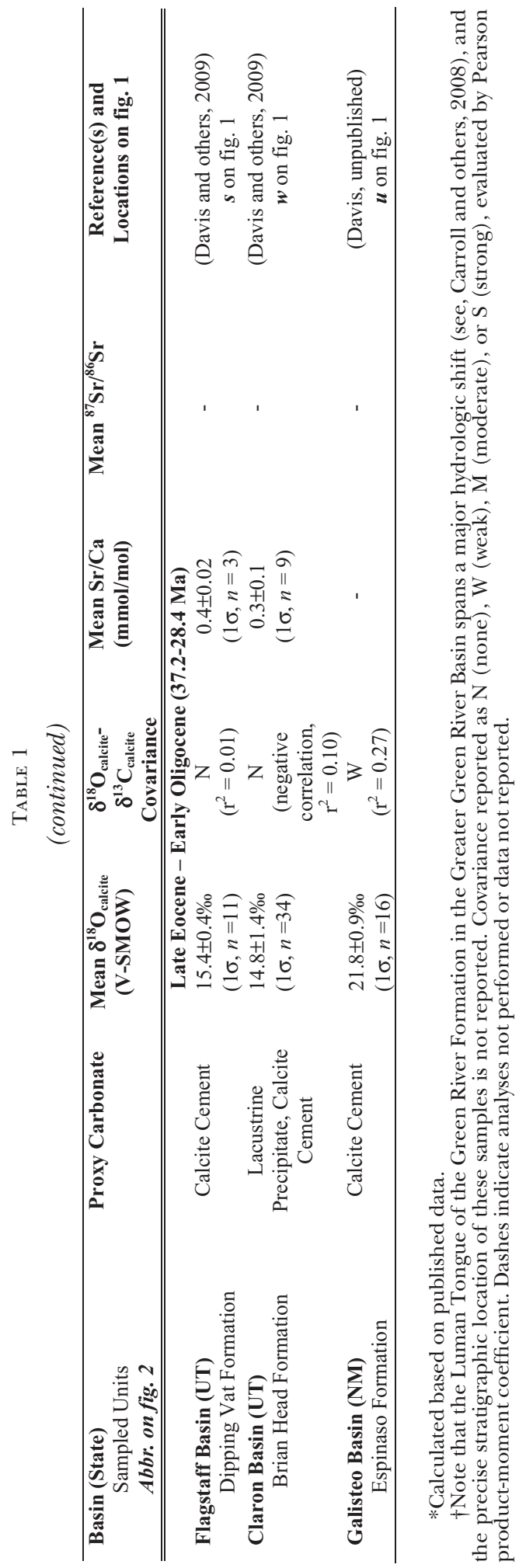




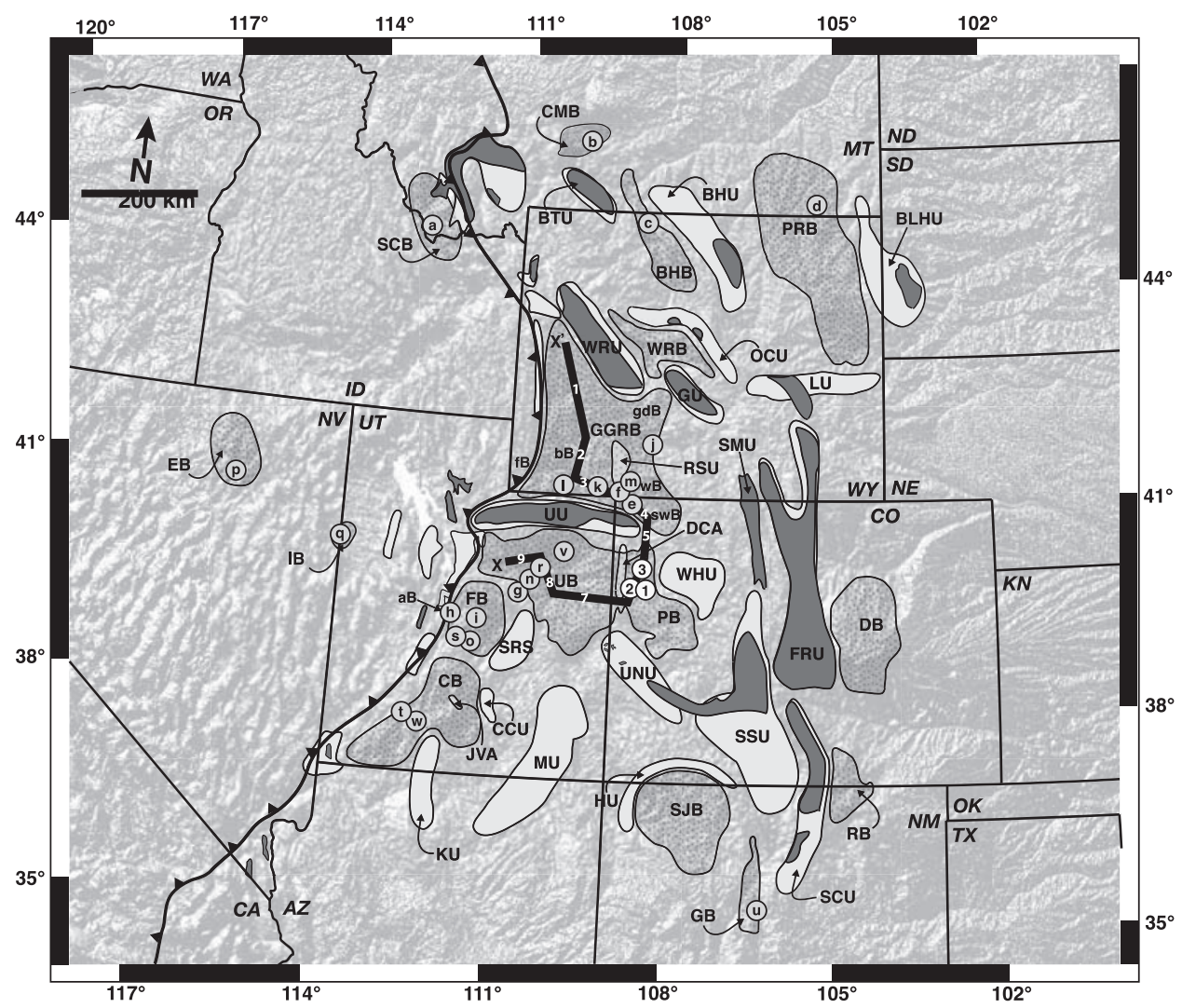

Fig. 1. Digital elevation map of modern topography of the central North American Cordillera (UTM Zone 13N) with Paleogene structures superimposed (location and extent of structures after Dickinson and others, 1986, 1988). Basins are lightly stippled and uplifts are shaded gray. Darker shading indicates exposed Precambrian rock where ${ }^{87} \mathrm{Sr} /{ }^{86} \mathrm{Sr}$ ratios can be in excess of 1.0 , while lighter shading indicates exposures of Paleozoic and Mesozoic rocks with ${ }^{87} \mathrm{Sr} /{ }^{86} \mathrm{Sr}$ ratios $<0.710$ [extent of basins and uplifts after Dickinson and others (1988), Precambrian exposures from Foster and others (2006), and isotopic composition from sources cited in text and listed in table A6 of Appendix A]. Bold line shows the Sevier fold-and-thrust belt, teeth on the upper plate. Cross-section chronostratigraphy along $\mathrm{X}-\mathrm{X}^{\prime}$ shown in figure 2. Major structures are labeled as follows: BHB, Bighorn Basin; BHU, Bighorn Uplift; BLHU, Black Hills Uplift; BTU, Beartooth Uplift; CB, Claron Basin; CCU, Circle Cliffs Uplift; CMB, Crazy Mountain Basin; CMU, Crazy Mountain Uplift; DB, Denver Basin; DCA, Douglas Creek Arch; EB, Elko Basin; FB, Flagstaff Basin (sub-basin: aB, Axhandle Basin); FRU, Front Range Uplift; GB, Galisteo Basin; GGRB, Greater Green River Basin (sub-basins: bB, Bridger Basin; gdB, Great Divide Basin; wB, Washakie Basin; swB, Sand Wash Basin); GU, Granite Mountain Uplift; HM, Hogback Monocline; IB, Ibapah Basin; JVA, Johns Valley and Upper Valley Anticlines; KU, Kaibab Uplift; LU, Laramie Uplift; MU, Monument Upwarp; OCU, Owl Creek Uplift; PB, Piceance Creek Basin; PRB, Powder River Basin; RB, Raton Basin; RSU, Rock Springs Uplift; SCB, Sage Creek Basin; SCU, Sangre de Cristo Uplift; SJB, San Juan Basin; SMU, Sierra Madre Uplift; SSU, Sawatch-San Luis Uplift; SRS, San Rafael Swell; UB, Uinta Basin; UNU, Uncompahgre Uplift; UU, Uinta Uplift; WHU, White River Uplift; WRB, Wind River Basin; WRU, Wind River Uplift. Numbered and lettered circles correspond to sampling localities of this study and previous studies, respectively, as listed in table 1.

Samples of lacustrine carbonate are particularly useful isotopic proxies of paleoenvironment because of the continuity of lake deposits and their sensitivity to climatic and tectonic processes (Carroll and Bohacs, 1999; Bohacs and others, 2000). We analyzed lacustrine carbonate samples from the Piceance Creek Basin of northwest Colorado (fig. 1) for oxygen, carbon, and strontium isotope composition, as well as calcium and strontium concentrations. 
GEOLOGIC SETTING AND STRATIGRAPHY

Evidence of each phase in the development of Cordilleran drainage patterns is preserved by lacustrine units in the intraforeland Piceance Creek Basin of northwest Colorado (fig. 1). Four Laramide uplifts bound the Piceance Creek Basin: the White River Uplift to the northeast, the Uinta Uplift to the northwest, the Uncompahgre Uplift to the southwest, and the Sawatch Uplift to the southeast (fig. 1). Units sampled for isotopic analyses belong to two formations:

\section{Green River Formation}

Lacustrine deposits in the Piceance Creek Basin are part of the carbonate-rich Green River Formation (Hayden, 1869; Bradley, 1931). Though the lake in the Piceance Creek Basin has often been referred to as Lake Uinta by earlier workers acknowledging its merger with the lake in the Uinta Basin during a lake highstand at 48.6 Ma (Smith and others, 2008a), it is herein distinguished as the Piceance lake. Lacustrine deposition first expanded across the Piceance Creek Basin in the Early Eocene as recorded by the shallow lacustrine, paludal, and fluvial beds of the Cow Ridge Member (Tgc, fig. 2) which occur in the basin center isolated between fluvial redbeds of the main body and an overlying tongue of the DeBeque (Wasatch) Formation ( $\boldsymbol{T} \boldsymbol{d}$, fig. 2, Donnell, 1969; Johnson, 1984; Kihm, ms, 1984). At 52 Ma, the freshwater Piceance lake returned and expanded widely, evidenced by the fossiliferous Long Point bed ( $\boldsymbol{l}$, fig. 2, denoted by cross symbols at $\sim 100 \mathrm{~m}$ in fig. 3) (Johnson, 1984). This Long Point transgression marks the base of three roughly time-equivalent facies: The Anvil Points and Douglas Creek Members (Tga and Tgd, respectively, fig. 2) are arenaceous, nearshore lake facies deposited along the eastern and western basin margins, respectively. The Garden Gulch Member (Tgg, fig. 2) is made up of argillaceous, profundal deposits in the basin center (Hail, 1992). Overlying these older members in the Piceance Creek Basin are marl, oil shale (kerogen-rich marl), and evaporite deposits belonging to the Parachute Creek Member (Tg $\boldsymbol{p}$, fig. 2), which includes the well-known Mahogany Zone ( $\boldsymbol{m}$, fig. 2) of rich oil shale deposited during the lake highstand at 48.6 Ma (Brobst and Tucker, 1973; Smith and others, 2008a).

\section{Uinta Formation}

In the Middle Eocene, at $\sim 48 \mathrm{Ma}$, sandy, volcaniclastic sediments assigned to the Uinta Formation ( $\boldsymbol{T} \boldsymbol{u}$, fig. 2) prograded south into the Piceance Creek Basin (Surdam and Stanley, 1980; Smith and others, 2008a). Strata of the Uinta Formation intertongue with the Parachute Creek Member of the Green River Formation over several hundred meters (Hail, 1987). Although the tongues of the Uinta Formation have not been named, a number of the regressing lacustrine marls are useful stratigraphic markers that have been formally named tongues of the Green River Formation, giving them status as formation members (Duncan and others, 1974; O'Sullivan, 1975; Hail, 1977). Named tongues sampled in this study include (from oldest to youngest) the Yellow Creek, Dry Fork, Black Sulphur, Coughs Creek, and Stewart Gulch Tongues. By $\sim 47 \mathrm{Ma}$, the encroaching Uinta Formation overwhelmed the lake, and fluvial deposits of the Uinta Formation completely filled the basin shortly thereafter.

ISOTOPIC APPROACHES TO BASIN EVOLUTION

In order to characterize the paleohydrology of the Piceance Creek Basin, we assembled $\mathrm{O}$ isotopic profiles of exposed lacustrine sediments of Paleogene age. $\mathrm{C}$ isotopes and $\mathrm{Sr} / \mathrm{Ca}$ ratios of carbonate were then used to evaluate the role of evaporation on the $\mathrm{O}$ isotope record. Evaporative effects can be assessed by the degree of covariance of $\delta^{13} \mathrm{C}-\delta^{18} \mathrm{O}$ values and $\mathrm{Sr} / \mathrm{Ca}$ ratios in carbonate samples. If evaporation is relatively high $\delta^{13} \mathrm{C}$ and $\delta^{18} \mathrm{O}$ values will covary because hydrologically closed lakes have long residence times allowing preferential outgassing of ${ }^{12} \mathrm{C}$-rich $\mathrm{CO}_{2}$ 


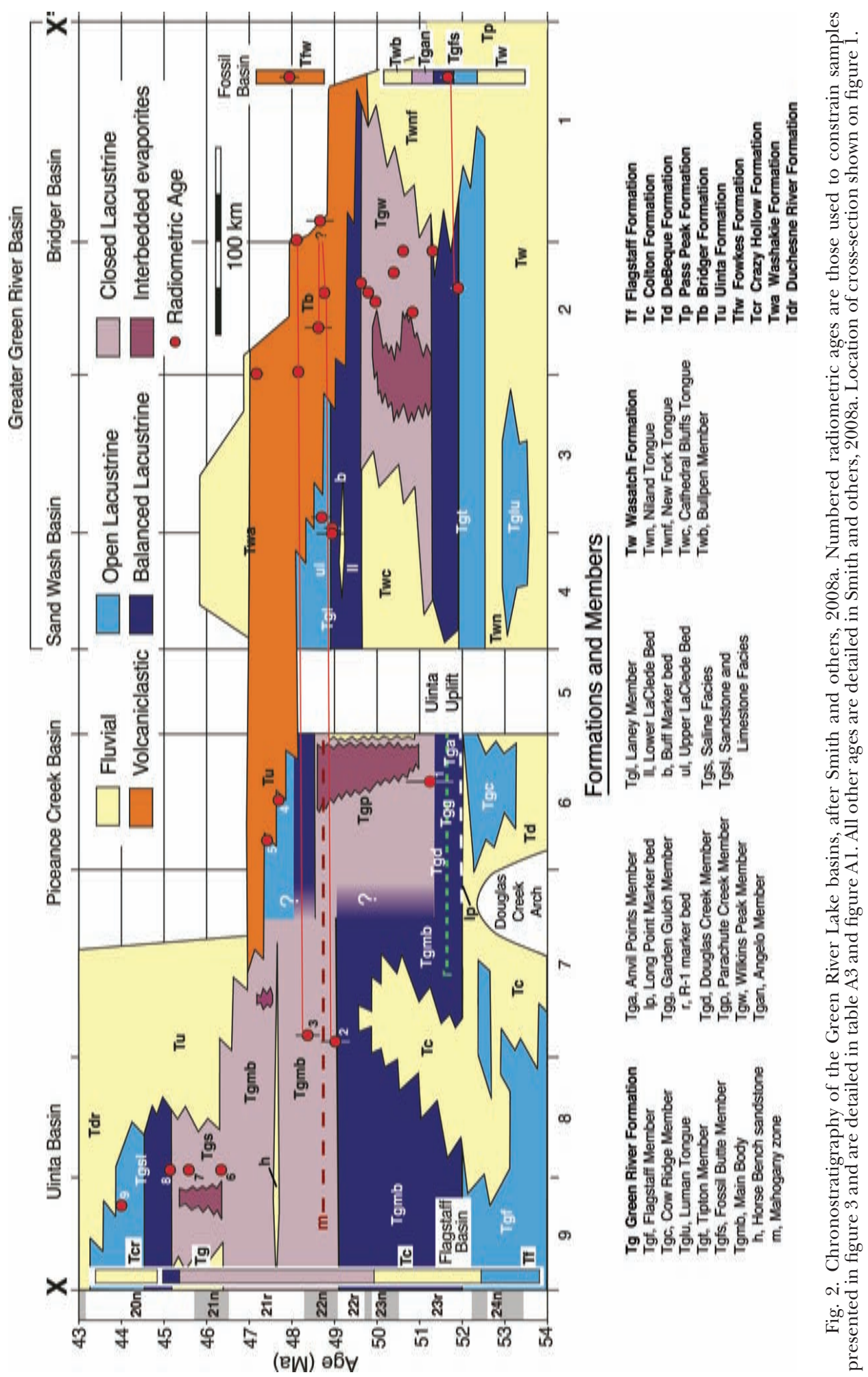




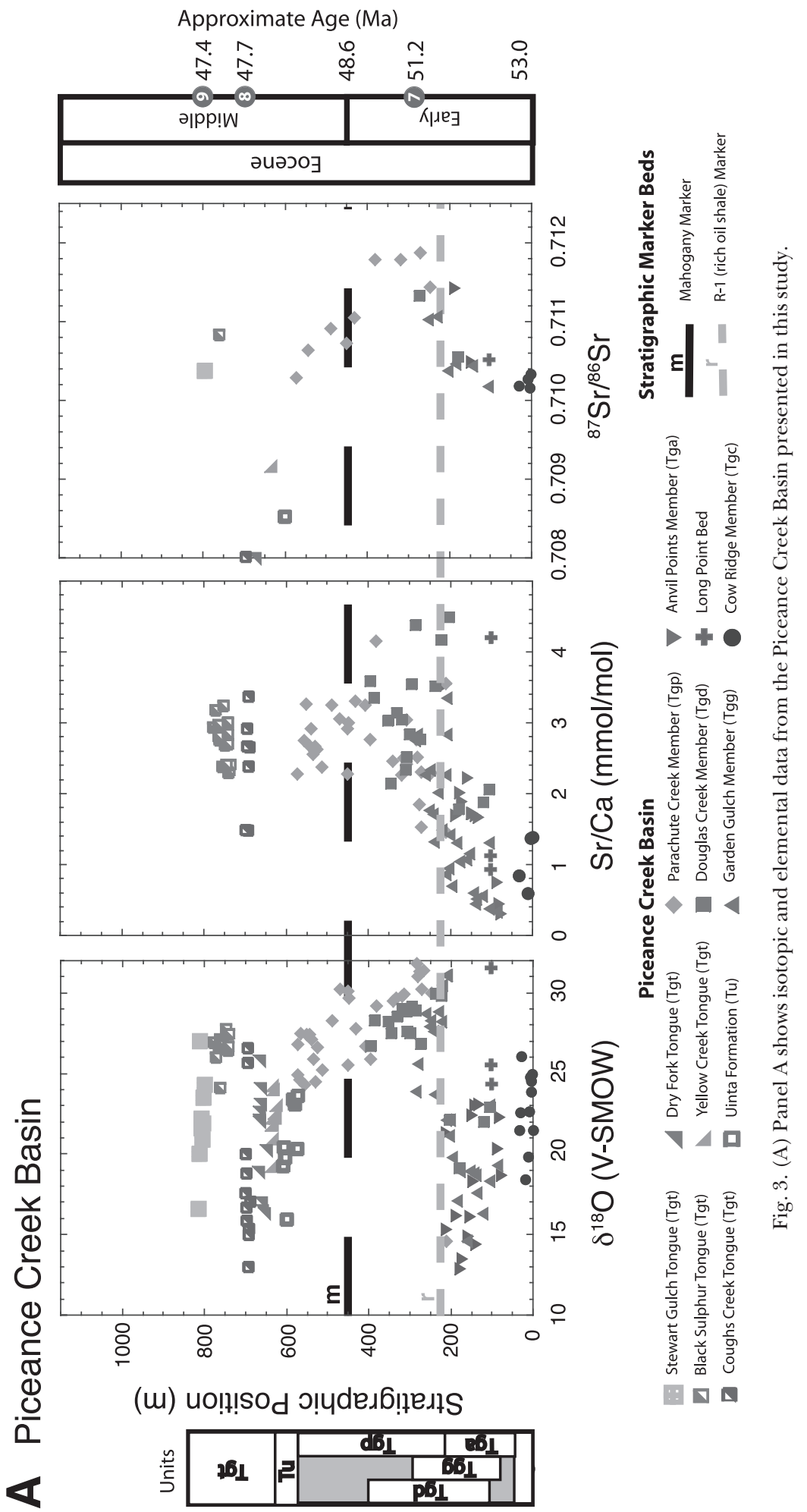




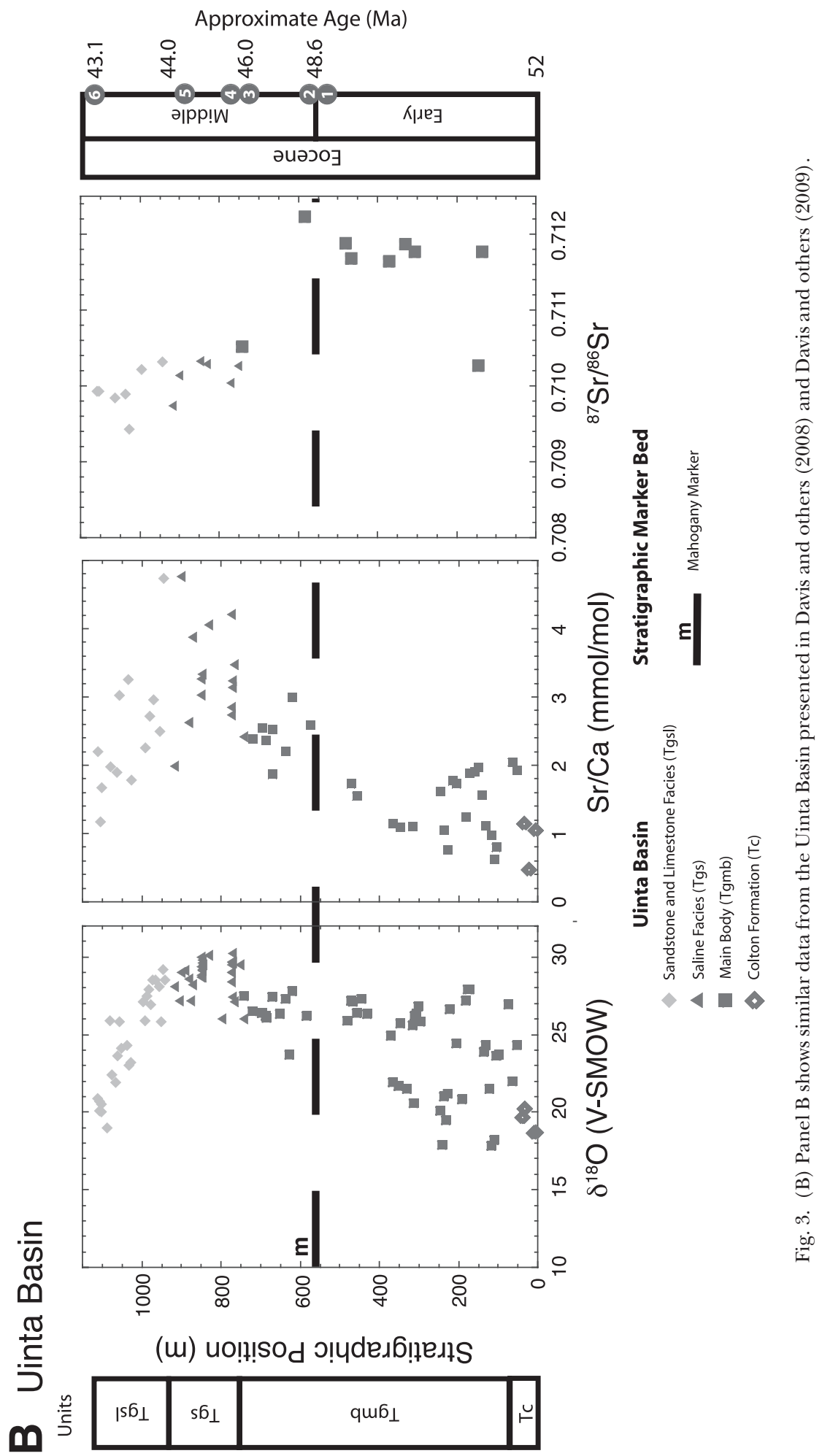


accompanied by evaporative enrichment of ${ }^{18} \mathrm{O}$ (Talbot and Kelts, 1990). Sr/Ca ratios will also be high in evaporative lakes as the partitioning of $\mathrm{Sr}$ between host water and authigenic carbonate is proportional to the ratio of $\mathrm{Sr}^{2+}$ to $\mathrm{Ca}^{2+}$ in the water (Müller and others, 1972). In hydrologically closed lakes, $\mathrm{Sr}^{2+}$ is not flushed from the lake, and as $\mathrm{Ca}^{2+}$ is taken up by precipitating $\mathrm{CaCO}_{3}, \mathrm{Sr}^{2+}$ is progressively concentrated and incorporated into authigenic carbonates (Eugster and Kelts, 1983). Carbon isotopes can also be used to assess the role of diagenesis on the $O$ isotope composition of carbonates. Late stage diagenesis often results in relatively low $\mathrm{O}$ isotope values (Morrill and Koch, 2002) as a result of equilibration of carbonate with meteoric waters at high temperatures. Conversely, $\delta^{13} \mathrm{C}$ values of early diagenetic carbonates may be affected by bacterially mediated redox reactions, while $\delta^{18} \mathrm{O}$ values of such diagenetic phases continue to record the isotopic composition of sediment pore waters (Talbot and Kelts, 1990), resulting in non-covariance of $\mathrm{C}$ and $\mathrm{O}$ isotopes in lacustrine sediments (Talbot, 1990; Talbot and Kelts, 1990).

We used Sr isotopes of authigenic carbonate to determine whether the source of the water supplied to these lakes has changed over time. The ratio of ${ }^{87} \mathrm{Sr} /{ }^{86} \mathrm{Sr}$ in lacustrine carbonates has been recognized as a valuable method for reconstructing lake paleohydrology (Rhodes and others, 2002; Hart and others, 2004; Davis and others, 2008; Gierlowski-Kordesch and others, 2008). Mass-dependent fractionation of ${ }^{87} \mathrm{Sr} /{ }^{86} \mathrm{Sr}$ ratios is insignificant and corrected for during analysis, meaning that authigenic minerals record the $\mathrm{Sr}$ isotope composition of lake water at the time of their precipitation. The ${ }^{87} \mathrm{Sr} /{ }^{86} \mathrm{Sr}$ ratio of waters is controlled by contact with rocks in the drainage area, and especially more soluble carbonate rocks (Palmer and Edmond, 1992; Jacobsen and Blum, 2000). In the Paleogene Cordillera, basement uplifts in many cases exposed Precambrian crystalline rocks with high ${ }^{87} \mathrm{Sr} /{ }^{86} \mathrm{Sr}$ ratios (commonly $>1.0$ ) which were in turn flanked by Paleozoic and Mesozoic carbonates and siliclastics with much lower ${ }^{87} \mathrm{Sr} /{ }^{86} \mathrm{Sr}$ ratios $(\leq 0.710$, see fig. 1). Such heterogeneities in the $\mathrm{Sr}$ isotope ratios of lithologies present in the drainage basin are homogenized in lake water so that when carbonate precipitates, its $\mathrm{Sr}$ isotope composition reflects the weighted average of isotopically distinct inflows to the lake.

Although differential weathering of minerals can cause the concentration of radiogenic strontium in solid weathering products (for example, clays), research indicates that this effect is generally quite small, and that the isotopic composition and abundance of source rocks effectively control the ${ }^{87} \mathrm{Sr} /{ }^{86} \mathrm{Sr}$ ratio of strontium in solution (Brass, 1975). Furthermore, it has been demonstrated that the ${ }^{87} \mathrm{Sr} /{ }^{86} \mathrm{Sr}$ ratios of soil carbonate (also a product of weathering reactions) are similar to stratigraphically equivalent fish and mollusk fossils (which reflect surface water) (Quade and others, 1997).

Finally, in order to better characterize the maximum depositional age of lacustrine deposits and also examine the potential of detrital zircon data as an indicator of provenance, we also sampled tuffaceous lake beds where they occurred.

\section{MATERIALS AND METHODS}

\section{Sample Collection}

We collected authigenic carbonate samples from 11 stratigraphic sections of Paleogene lacustrine facies in 3 localities of the Piceance Creek Basin (fig. 1 and tables A1 and A2) and analyzed their $\mathrm{O}$ and $\mathrm{C}$ isotope composition $(\mathrm{n}=186)$, Sr isotope composition $(n=30)$ and $\mathrm{Sr} / \mathrm{Ca}$ ratios $(\mathrm{n}=114)$. Samples were predominantly limestone, although carbonate was variably argillaceous (that is, marls or "oil-shales") and, less commonly, arenaceous. Isotopic analyses were performed only on micritic samples with no evidence of recrystallization. Where present, we 
also collected tuffaceous arenites for U-Pb geochronologic analyses of zircon. Detailed information and key references of each sampled section are included in Appendix A (fig. A1 and tables A1, A3 and A4).

\section{U-Pb Geochronologic Analyses of Zircon}

$\mathrm{U}-\mathrm{Pb}$ geochronological analyses of 7 tuffaceous samples from the Piceance Creek Basin as well as 2 samples from the Uinta Basin (details in Appendix A) were carried out using both the Stanford/U.S. Geological Survey (USGS) Sensitive High-Resolution Ion Microprobe (SHRIMP-RG) and a laser ablation multicollector inductively coupled plasma mass spectrometer (LA-MC-ICPMS) at the University of Arizona.

For ion microprobe analyses, zircon separates were mounted in epoxy, polished, imaged by cathodoluminescence on a JEOL 5600LLV scanning electron microscope, and gold coated. Analytical spots 25 to $30 \mu \mathrm{m}$ in diameter on the zircon grains were sputtered using an $\sim 10 \mathrm{nA}$ primary beam of ${ }^{16} \mathrm{O}_{2}^{-}$ions. After rastering the spot for $90 \mathrm{~s}$ to remove surficial contaminants, the secondary ion beam was repeatedly scanned for ${ }^{90} \mathrm{Zr}_{2}{ }^{16} \mathrm{O},{ }^{204} \mathrm{~Pb},{ }^{206} \mathrm{~Pb},{ }^{207} \mathrm{~Pb},{ }^{238} \mathrm{U},{ }^{232} \mathrm{Th}^{16} \mathrm{O}$ and ${ }^{238} \mathrm{U}^{16} \mathrm{O}$. Zircon standard R33 (419 Ma from monzodiorite, Braintree Complex, Vermont) was used as a concentration standard. Concentration measurements were corrected and reduced using SQUID software (Version 1.02; Ludwig, 2001).

Samples failing to yield a coherent age group were assumed detrital, and were further analyzed by LA-MC-ICPMS using methods described by Gehrels and others (2008). Gold coat was quantitatively removed from microprobe zircon mounts by immersion in a saturated solution of potassium iodide (KI) for an hour at 80 to $90{ }^{\circ} \mathrm{C}$. Mounts were then placed in an LA-MC-ICMP and ablated with a New Wave DUV193 Excimer laser (operating at a wavelength of $193 \mathrm{~nm}$ ) using a spot diameter of 25 or 35 $\mu \mathrm{m}$, depending on zircon grain size. Entrained in helium gas, ablated material was carried into the plasma source of a Micromass Isoprobe where $\mathrm{U}, \mathrm{Th}$, and $\mathrm{Pb}$ isotopes were measured simultaneously. All measurements were made in static mode, using Faraday detectors for ${ }^{238} \mathrm{U},{ }^{232} \mathrm{Th},{ }^{208-206} \mathrm{~Pb}$, and an ion-counting channel for ${ }^{204} \mathrm{~Pb}$. Each analysis consisted of one $12 \mathrm{~s}$ integration on peaks with the laser off (for backgrounds), twelve $1 \mathrm{~s}$ integrations with the laser firing, and a $30 \mathrm{~s}$ delay to purge the previous sample and prepare for the next analysis. A Sri Lanka zircon standard $(563.5 \pm 3.2 \mathrm{Ma}, 2 \sigma)$ was used as a concentration standard (Gehrels, unpublished data).

\section{Isotopic and Elemental Analyses of Carbonate}

$\mathrm{Sr}, \mathrm{C}$ and $\mathrm{O}$ isotope values of the carbonate samples were measured in the mass spectrometry laboratories at Stanford University. For Sr isotope analysis, Sr was extracted from bulk carbonate samples using $1 \mathrm{M}$ acetic acid $\left(\mathrm{CH}_{3} \mathrm{COOH}\right)$ to ensure that potentially existing silicate minerals were not dissolved. The solution was centrifuged, transferred into clean Teflon vials, and evaporated. The evaporate was then treated with concentrated $\mathrm{HNO}_{3}$ to oxidize traces of organic material and facilitate re-dissolution of the sample with $2.5 \mathrm{~N} \mathrm{HCl}$. Aliquots of each sample were loaded onto cation exchange columns using Biorad AG50x8 (200-400 mesh) resin, and eluted with $2.5 \mathrm{~N} \mathrm{HCl}$. All reagents were distilled. Purified $\mathrm{Sr}$ fractions were measured on a Finnigan MAT262 Thermal Ionization Mass Spectrometer using Ta single filaments and $0.25 \mathrm{~N} \mathrm{H}_{3} \mathrm{PO}_{4}$. Ratios of ${ }^{88} \mathrm{Sr},{ }^{87} \mathrm{Sr},{ }^{86} \mathrm{Sr}$, and ${ }^{84} \mathrm{Sr}$ were scanned at least 80 times per sample. ${ }^{87} \mathrm{Sr} /{ }^{86} \mathrm{Sr}$ ratios were corrected for instrumental fractionation using the natural ${ }^{88} \mathrm{Sr} /{ }^{86} \mathrm{Sr}$ ratio of 8.375209 . Routine standard measurements yield a ${ }^{87} \mathrm{Sr} /{ }^{86} \mathrm{Sr}$ ratio of $0.71033 \pm 0.00001(2 \sigma: \mathrm{n}=64)$ for the NBS-987 $\mathrm{Sr}$ standard. The analytical precision is 0.003 percent or less. Blanks were less than $0.5 \mathrm{ng} \mathrm{Sr}$. 
$\mathrm{O}$ and $\mathrm{C}$ isotope analyses of carbonate were determined using the phosphoric acid digestion method of McCrea (1950) coupled on-line with a gas ratio mass spectrometer. Using this method, between 300 to $500 \mu \mathrm{g}$ of sample material was drilled from each sample, sealed in reaction vials, flushed with helium and reacted with pure $\mathrm{H}_{3} \mathrm{PO}_{4}$ at $72^{\circ} \mathrm{C}$. Evolved $\mathrm{CO}_{2}$ in the vial headspace was then sampled using a Finnigan GasBench II, connected to a Finnigan MAT Delta ${ }^{\text {Plus }}$ XL mass spectrometer. Replicate analyses of NBS-19 (limestone) and laboratory standards yielded a precision \pm 0.2 permil or better for both $\delta^{18} \mathrm{O}$ and $\delta^{13} \mathrm{C}$.

$\mathrm{Sr} / \mathrm{Ca}$ ratios of carbonate were measured using an inductively coupled plasmaatomic emission spectrometer (ICP-AES) at Stanford University. Samples were first digested in concentrated $\mathrm{HNO}_{3}$, diluted with Mega-Pure water and filtered. Total dissolved $\mathrm{Ca}^{2+}$ and $\mathrm{Sr}^{2+}$ were measured at wavelengths 317.9 and $407 \mathrm{~nm}$, respectively (for example, de Villiers and others, 2002). Replicate analyses of prepared blanks and standard solutions of varying known concentrations indicated detection limits for $\mathrm{Ca}^{2+}$ and $\mathrm{Sr}^{2+}$ of 6 and $0.1 \mu \mathrm{g} \mathrm{L}{ }^{-1}$, respectively, and precision better than $15 \mu \mathrm{g} \mathrm{L}^{-1}$ for $\mathrm{Ca}^{2+}$ and $1 \mu \mathrm{g} \mathrm{L}{ }^{-1}$ for $\mathrm{Sr}^{2+}$ (that is, better than $0.1 \mathrm{mmol} / \mathrm{mol}$ for $\mathrm{Sr} / \mathrm{Ca}$ ratios).

\section{RESULTS}

Analyses of carbonate from the Piceance Creek Basin show first order trends that are here presented as three stratigraphic/temporal intervals (table 1).

\section{U-Pb Geochronological Analyses}

Of the 7 Piceance samples analyzed, 2 from Tongues of the Green River Formation yielded coherent age groups that we interpret as maximum depositional ages (numbered 8 and 9 in figs. 2 and 3A; data and diagrams in Appendix A). The other 5 Piceance samples and 2 additional samples from the Uinta Basin contained zircons of variable ages that do not help to constrain depositional age, but which are useful as indicators of provenance (fig. 4). Such detrital samples from older units (DeBeque Formation and Anvil Points in the Piceance Basin and Flagstaff Member and Colton Formation in the Uinta Basin) contain few zircons older than $800 \mathrm{Ma}$. Samples from younger units (Garden Gulch Member, Kimball Mountain Tuff Bed, and Coughs Creek Tongue in the Piceance Basin) increasingly contain Grenville- (1315-1000 Ma) and Paleoproterozoic-age (1615-1800 Ma) grains.

\section{Prior to $\sim 52 \mathrm{Ma}$}

Samples deposited between the formation of the Piceance lake (fig. 2, $\boldsymbol{T g c}$ ) and $\sim 52 \mathrm{Ma}$ (fig. 2, including parts or all of $\boldsymbol{T g a}, \boldsymbol{T g d}$, and $\boldsymbol{T g g}$ ) give a mean $\delta^{18} \mathrm{O}_{\text {calcite }}$ value of 20.3 permil (fig. 3A), a mean $\mathrm{Sr} / \mathrm{Ca}$ ratio of $1.3 \mathrm{mmol} / \mathrm{mol}$ (figs. 3A and 5), and a mean ${ }^{87} \mathrm{Sr} /{ }^{86} \mathrm{Sr}$ ratio of 0.7105 (fig. $3 \mathrm{~A}, 2 \sigma=0.0008, \mathrm{n}=11$ ). $\delta^{18} \mathrm{O}_{\text {calcite }}$ and $\delta^{13} \mathrm{C}_{\text {calcite }}$ do not covary in samples from this period $\left(\mathrm{r}^{2}=0.02\right.$, fig. 6 , panels $\boldsymbol{T} \boldsymbol{g} \boldsymbol{c}$ and $\left.\boldsymbol{T} \boldsymbol{g} \boldsymbol{a}\right)$. Here as well as in all other units, samples from similar stratigraphic intervals yield similar $\mathrm{Sr}$ isotope ratios irrespective of mineralogy, texture, $\mathrm{O}$ isotope composition and $\mathrm{Sr} / \mathrm{Ca}$ ratio.

\section{Between $\sim 52$ and $48.6 \mathrm{Ma}$}

Beginning at $\sim 52 \mathrm{Ma}$ (as constrained by radiometric age of the overlying Yellow Tuff, \#1 in figs. 2 and 3), the mean $\delta^{18} \mathrm{O}_{\text {calcite }}$ value of samples increased by $\sim 7.6$ permil from 20.3 permil to 27.9 permil (fig. $3 \mathrm{~A}$ ). During the same interval, the mean $\mathrm{Sr} / \mathrm{Ca}$ ratio increases to $2.7 \mathrm{mmol} / \mathrm{mol}$ (figs. $3 \mathrm{~A}$ and 5 ), and $\delta^{18} \mathrm{O}_{\text {calcite }}{ }^{-\delta^{13}} \mathrm{C}_{\text {calcite }}$ values in deposited units display strong covariance $\left(\mathrm{r}^{2}=0.61\right.$, fig. 6, panels $\left.\boldsymbol{T} \boldsymbol{g} \boldsymbol{d}, \boldsymbol{T} \boldsymbol{g g}, \boldsymbol{T g} \boldsymbol{p}\right)$. Coincident with these shifts, ${ }^{87} \mathrm{Sr} /{ }^{86} \mathrm{Sr}$ ratios increase steadily to a maximum of 0.7119 (fig. 3A, mean $=0.7113,1 \sigma=0.0005, \mathrm{n}=9$ ). 


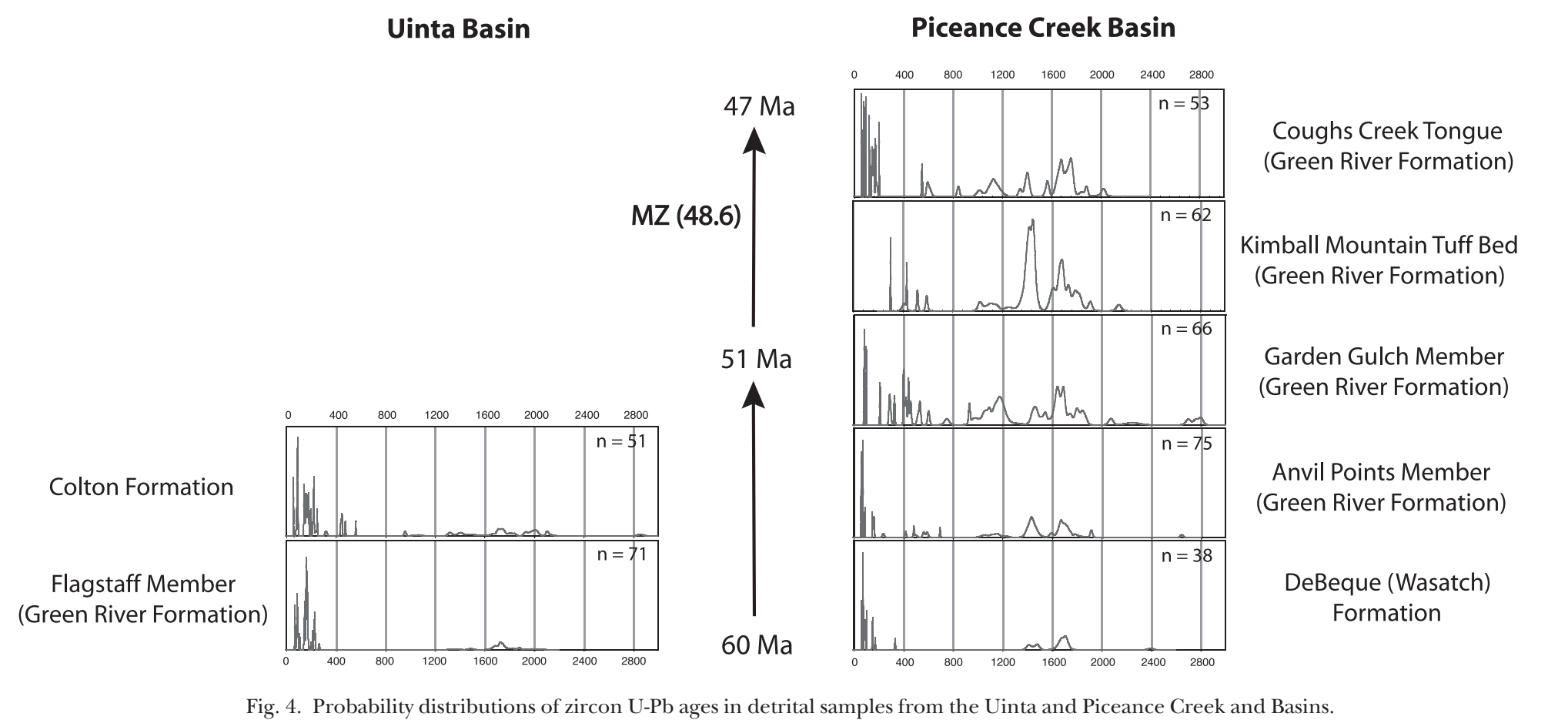

Fig. 4. Probability distributions of zircon U-Pb ages in detrital samples from the Uinta and Piceance Creek and Basins. 


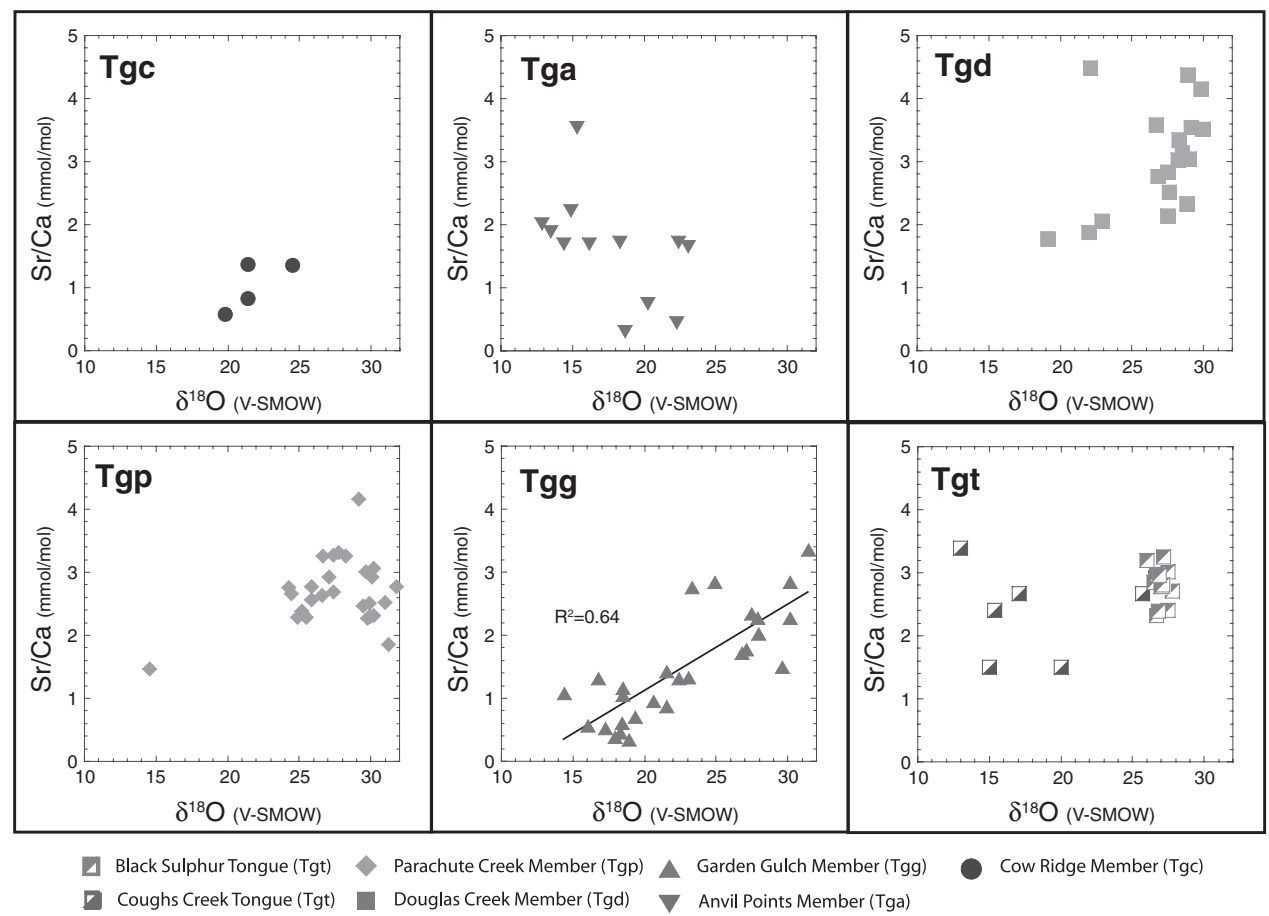

Fig. 5. Relationship of $\delta^{18} \mathrm{O}_{\text {calcite }}$ and $\mathrm{Sr} / \mathrm{Ca}$ ratios in sampled units of the Piceance Creek Basin.

\section{Between 48.6 and $\sim 47 \mathrm{Ma}$}

Beginning at $48.6 \mathrm{Ma}, \delta^{18} \mathrm{O}_{\text {calcite }}$ values decrease in two recognizable stages, first by $\sim 1.2$ permil from 27.9 permil to 26.7 permil in the upper Parachute Creek Member (fig. 3A, $\boldsymbol{T g} \boldsymbol{p}$ ) and then continuing more sharply at $\sim 48$ Ma to a mean value of 21.5 permil in the Uinta Formation and tongues of the Green River Formation (fig. 3A, Tu and $\boldsymbol{T g t})$. The two stages are also delineated by ${ }^{87} \mathrm{Sr} /{ }^{86} \mathrm{Sr}$ ratios, which first decrease to a mean of 0.7106 in the upper Parachute Creek Member (fig. 3A, $2 \sigma=0.0005, \mathrm{n}=4$ ) and then drop as low as 0.7080 in the Uinta Formation and Tongues of the Green River Formation (fig. 3A, mean $=0.7092,2 \sigma=0.0024, \mathrm{n}=6$ ). $\mathrm{Sr} /$ Ca ratios in samples of the upper Parachute Creek Member (the first stage) maintain the same mean value, 2.7 $\mathrm{mmol} / \mathrm{mol}$, as samples from the interval between $\sim 52$ and 48.6 Ma with little variability (figs. 3A and $5,1 \sigma=0.3, \mathrm{n}=13$ ). $\mathrm{Sr} / \mathrm{Ca}$ ratios remain high in samples of the Tongues of the Green River Formation deposited during this second stage (mean $=2.7$ $\mathrm{mmol} / \mathrm{mol}$, figs. $3 \mathrm{~A}$ and $5,1 \sigma=0.5, \mathrm{n}=20)$ and $\delta^{18} \mathrm{O}_{\text {calcite }}-\delta^{13} \mathrm{C}_{\text {calcite }}$ values from the combined Uinta Formation and Tongues continue to display strong covariance $\left(\mathrm{r}^{2}=\right.$ 0.61, fig. 6, panel Tu-Tgt).

\section{Discussion}

The isotopic and elemental results from the Piceance Creek Basin are here interpreted in the context of results from previous studies of the central North American Cordillera (table 1) - especially recent work in the neighboring Greater Green River (Rhodes and others, 2002; Carroll and others, 2008) and Uinta (Davis and others, 2008, 2009) Basins which contained other large lakes of the Green 


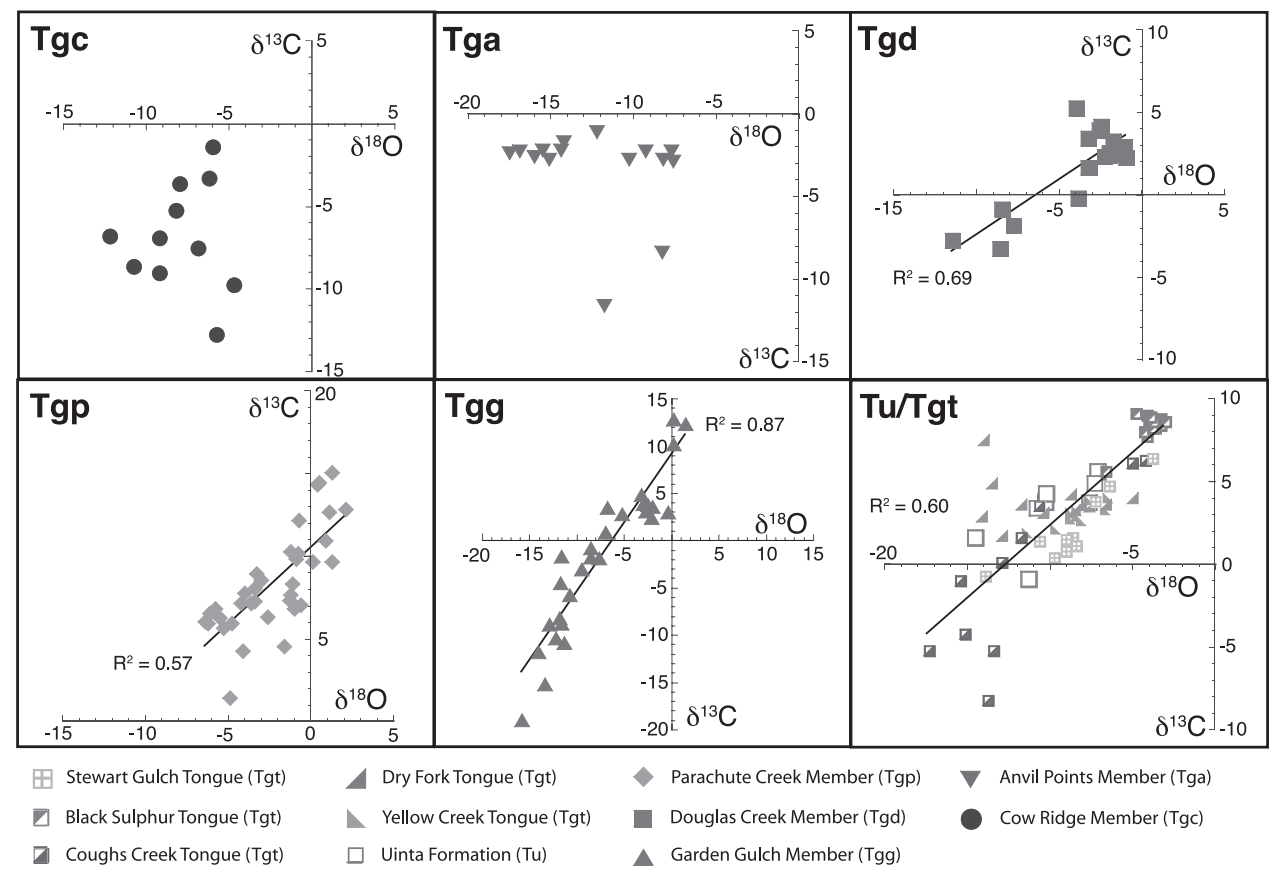

Fig. 6. Isotopic covariance of $\delta^{18} \mathrm{O}_{\text {calcite }} \delta^{13} \mathrm{C}_{\text {calcite }}$ in sampled units of the Piceance Creek Basin. $\delta^{18} \mathrm{O}_{\text {calcite }}$ is plotted relative to the PeeDee Belemnite standard (V-PDB).

River lake system during the Paleogene (figs. 1 and 2). Where relevant, interpretations also reference Pleistocene Lake Bonneville and the modern Great Salt Lake of Utah, whose location, hydrology and catchment geology closely resemble the Green River lakes, which preceded them. The new results thereby add to a growing consensus that topographic growth during the Laramide Orogeny caused largescale integration of Cordilleran drainage patterns that in turn dictated the hydrologic regime of intraforeland lake basins. Following is a summary of the new and published isotopic and elemental results in support of this interpretation, presented chronologically.

\section{Sevier-Laramide Transition (Late Cretaceous-earliest Eocene)}

Between the Campanian and earliest Eocene, coeval with the onset of Laramidestyle deformation in the foreland, the highstanding Sevier fold-and-thrust belt drained east into a broad, low-relief foreland (fig. 7, panel $53 \mathrm{Ma}$; for example, Lawton, 1986; Goldstrand, 1994; Janecke and others, 2000; DeCelles, 2004; Gierlowski-Kordesch and others, 2008). Within the foreland, shallow lakes and rivers drained northeast from Utah and Colorado and southeast from Montana and Idaho to an outlet in the northeast Greater Green River Basin (Wyoming) that debouched eastward into the ancestral Great Plains (see for example, Hansen, 1965, 1985; Steidtmann, 1969; Dorr Jr. and others, 1977; Stanley and Collinson, 1979; Moncure and Surdam, 1980; Cole, 1985; Sklenar and Anderson, 1985; Roehler, 1993).

Isotopic and elemental data support a hydrologically open foreland receiving water from catchments in the fold-and-thrust belt. First, mean $\delta^{18} \mathrm{O}_{\text {calcite }}$ values of basinal proxies formed during this period are $\sim 20$ permil (table 1 , for example 

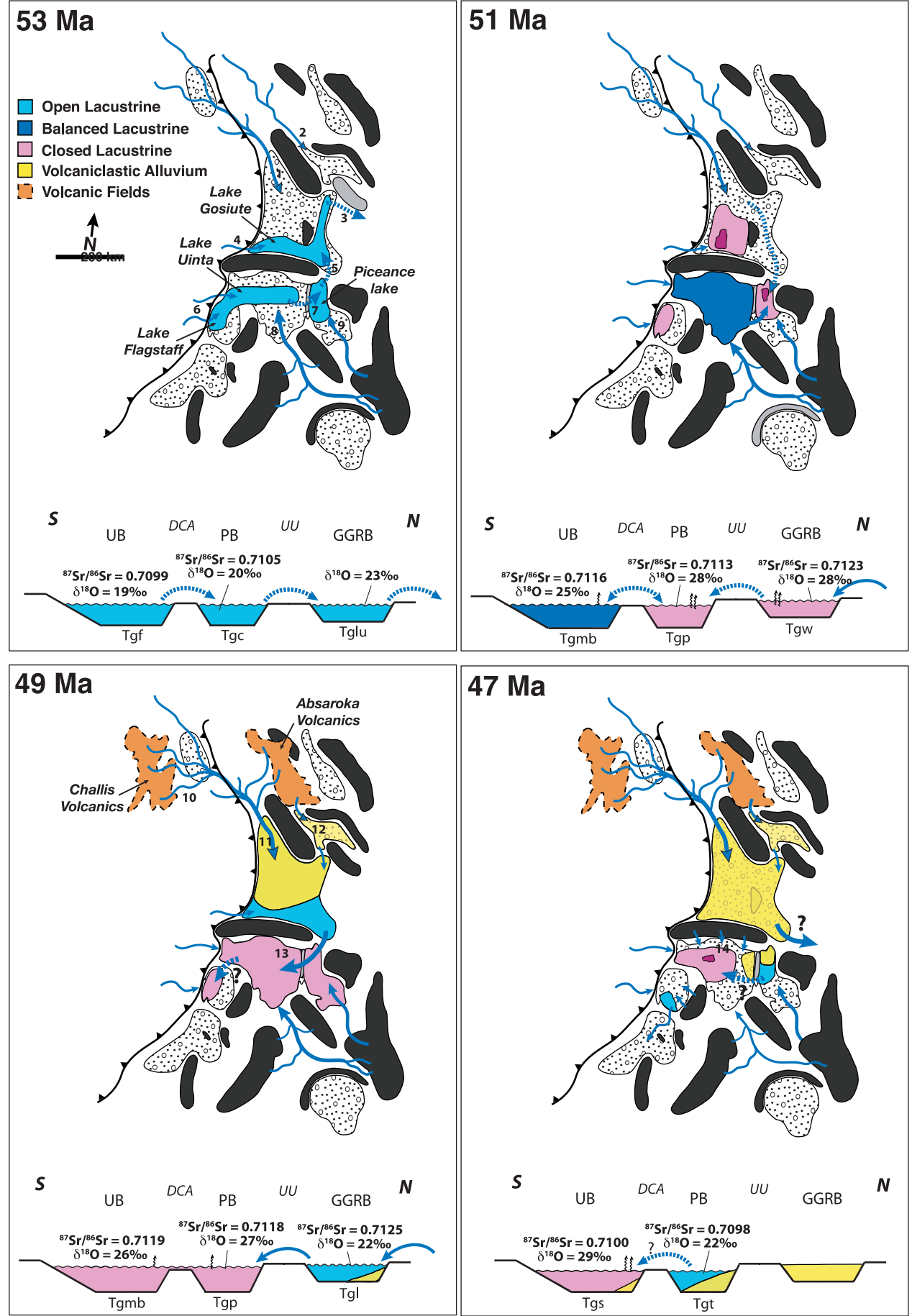

Fig. 7. Inferred development of foreland lakes and Cordilleran drainage patterns at four key times during the Paleogene (refer to fig. 1 for names of major structures and basins). Schematized cross-sections at bottom of each panel show the hydrology and isotopic compositions of the Greater Green River Basin (GGRB), Piceance Creek Basin (PCB) and Uinta Basin (UB), as separated by sills of the Uinta Uplift (UU) and the Douglas Creek Arch (DCA). Abbreviations of units deposited in each basin are shown in figure 2. Paleoflows are dashed where flow of surface waters was periodic, and are numbered according to the supporting references listed in Appendix A, table A5. 
"non-evaporitic" lakes of Drummond and others, 1993), with a minimum of 16.6 permil in the Crazy Mountain and Powder River Basins in the northern Cordillera (Dettman and Lohmann, 2000) and maxima of 22.1 permil in the Bighorn Basin (Koch and others, 1995), 22.6 permil in the Flagstaff Formation of central Utah (Weber, 1964), and 23.1 permil in the Luman Tongue in the Greater Green River Basin (Bridger subbasin) (Dettman and Lohmann, 2000). Such values are consistent with $\delta^{18} \mathrm{O}$ values of freshwater marls from Pleistocene Lake Bonneville (Provoand Bonneville-age samples reported in Oviatt and others, 1994; Nelson and others, 2005) and imply Eocene surface waters between -4 permil and -8 permil (compare, Fricke, 2003). Second, $\delta^{18} \mathrm{O}_{\text {calcite }}$ and $\delta^{13} \mathrm{C}_{\text {calcite }}$ values from these samples generally do not covary (table 1 and fig. 6). Moderate covariance in samples of the Flagstaff Formation and Luman Tongue (Weber, 1964; Dettman and Lohmann, 2000; see table 1) suggests the early Lakes Gosiute and Flagstaff, respectively, may have been hydrologically closed at intervals, helping to explain slightly higher $\delta^{18} \mathrm{O}_{\text {calcite }}$ values of those samples. Third, where $\mathrm{Sr} / \mathrm{Ca}$ ratios of these samples have been measured, they are relatively low (table 1): mean values range from $1.3 \pm 0.8 \mathrm{mmol} / \mathrm{mol}$ in the Piceance Creek Basin (this study, fig. 3), $0.75 \pm 0.47 \mathrm{mmol} / \mathrm{mol}$ in the Uinta Basin (Davis and others, 2008) and $<0.1$ $\mathrm{mmol} / \mathrm{mol}$ in the Flagstaff Basin (Gierlowski-Kordesch and others, 2008). Lastly, the ${ }^{87} \mathrm{Sr} /{ }^{86} \mathrm{Sr}$ ratios observed during this time in the Flagstaff, Uinta and Piceance Creek Basins (figs. 2 and 7, Tf, $\boldsymbol{T g} f$ and $\boldsymbol{T g} \boldsymbol{c}$, respectively) are consistently $\sim 0.710$ (table 1), suggesting catchments draining Paleozoic and Mesozoic carbonates then exposed in the fold-and-thrust belt to the west (Davis and others, 2008; GierlowskiKordesch and others, 2008). Modern rivers draining these rocks also have ${ }^{87} \mathrm{Sr} /{ }^{86} \mathrm{Sr}$ ratios $\leq 0.710$ and tend to have a disproportionately strong influence on the isotopic composition of the lakes they flow into due to their high [Sr] (Hart and others, 2004; Bright, 2009).

\section{Hydrologic Closure of the Green River Lake System (Early Eocene)}

At $\sim 52 \mathrm{Ma}$, the central Laramide foredeep became hydrologically closed, as recorded by the system of lakes which occupied the Greater Green River, Piceance Creek, and Uinta Basins (the Green River lake system). At lowstands, the Piceance Creek Basin was the final evaporating (that is, terminal) basin in the system, receiving periodic inflows from both the Greater Green River and Uinta Basins (fig. 7, panel 51 Ma). When prompted by climatic changes or increased inflows from upstream basins, the expanded Piceance lake coalesced with Lake Uinta overtop the Douglas Creek Arch (stratigraphy indicates lakes interconnected as early as the R-1 marker bed, Bartov and others, 2007; Smith and others, 2008a). Thus, the final evaporating basin of the closed lake system incorporated both the Uinta and Piceance Creek Basins when the lakes merged at highstands (for example, Kelts, 1988).

Isotopic and elemental results suggest changing foreland hydrology at this time. Mean $\delta^{18} \mathrm{O}_{\text {calcite }}$ values of samples from the Green River lakes increase in each basin by 5 to 8 permil, shifting to values $\geq 25$ permil (table 1 ), with maxima of 28.3 permil in the Wilkins Peak $(\boldsymbol{T} \boldsymbol{g} \boldsymbol{w})$ and lower Laney $(\boldsymbol{T} \boldsymbol{g} \boldsymbol{l})$ Members of the Greater Green River Basin (Norris and others, 1996; Carroll and others, 2008) and 27.9 permil in the Garden Gulch $(\boldsymbol{T g g})$, Douglas Creek $(\boldsymbol{T g} \boldsymbol{d})$ and lower Parachute Creek (Tg $\boldsymbol{p})$ Members of the Piceance Creek Basin (this study). Explanation of these high values by hydrologic closure and evaporative enrichment is supported by strong covariance of $\delta^{18} \mathrm{O}_{\text {calcite }}-\delta^{13} \mathrm{C}_{\text {calcite }}$ values (table 1 and fig. 6) and elevated $\mathrm{Sr} /$ Ca ratios (table 1, figs. 3 and 6). Modern carbonates from the analogous, closed Great Salt Lake display very similar $\delta^{18} \mathrm{O}_{\text {calcite }}$ values $(\sim 26-28 \%$ o $)$ which also covary with $\delta^{13} \mathrm{C}_{\text {calcite }}$ (Spencer and others, 1984). The mean $\delta^{18} \mathrm{O}_{\text {calcite }}$ value and 
$\mathrm{Sr} / \mathrm{Ca}$ ratio of Uinta Basin samples are somewhat lower than the other lake basins, 24.9 permil and $1.4 \mathrm{mmol} / \mathrm{mol}$, respectively, reflecting only episodic connections with the intensely evaporative Piceance lake.

Despite high values from Greater Green River Basin samples, Sr isotope ratios indicate periodic outflows from that basin south to the terminal Piceance Creek and Uinta Basins. The mean ${ }^{87} \mathrm{Sr} /{ }^{86} \mathrm{Sr}$ ratio of Greater Green River Basin (Washakie subbasin) samples at this time is $>0.7120$ (Rhodes and others, 2002; Carroll and others, 2008), evidence of catchments draining radiogenic rocks in adjacent, craton-cored uplifts (for example, the Wind River Uplift). Because groundwater fluxes have in some cases been observed to have a very strong effect on the ${ }^{87} \mathrm{Sr} /{ }^{86} \mathrm{Sr}$ ratio of modern river and lake waters in Utah (Jones and Faure, 1972; Hart and others, 2004; Bright, 2009), it is likely that springs flowing into the Greater Green River Basin were also a significant flux of radiogenic Sr given the greater duration water-rock contact and elevated temperatures at depth. Importantly, though, rocks in the subsurface rocks of foreland basin systems are generally no different than those exposed in surface.

Beginning $52 \mathrm{Ma}$, samples from the Uinta (Davis and others, 2008) and Piceance Creek (this study) Basins increase from $\sim 0.7100$ to 0.7116 and 0.7113 , respectively. Lack of radiogenic rocks in the uplifts adjacent to and south of these basins indicates the integration of catchments in the northern Cordillera (Davis and others, 2008), and suggests hydrologic closure throughout at least $500 \mathrm{~km}$ of the north central foreland.

\section{Integration of Axial Drainage and the Mahogany Highstand (early Middle Eocene)}

At $\sim 49 \mathrm{Ma}$, the Greater Green River Basin captured drainages flowing through the Challis volcanic field and Sage Creek Basin from headwaters in high-altitude north central Idaho (Kent-Corson and others, 2006; Carroll and others, 2008). Captured waters and their volcaniclastic sediment load quickly freshened and overfilled Lake Gosiute so that outflow to the Piceance Creek Basin became continuous (fig. 7, panel $49 \mathrm{Ma}$, Surdam and Stanley, 1980; Carroll and others, 2008). In turn, the continuous overspilling of Lake Gosiute led to a persistent merging of the Piceance lake with Lake Uinta by $48.6 \mathrm{Ma}$, when rich oil shales of the Mahogany Zone were deposited throughout the expanded yet evaporative lake ( $\mathrm{m}$, figs. 2 and 3). Connection of these sequential basins integrated axial drainage in the foreland over at least $1000 \mathrm{~km}$ from north central Idaho to northeast Utah (Davis and others, 2008).

Isotopic and elemental data record the expansion of the drainage basin and attendant changes in basin hydrology. At $\sim 49 \mathrm{Ma}$, mean $\delta^{18} \mathrm{O}_{\text {calcite }}$ values in the Sage Creek Basin of southwest Montana decrease by $\sim 10$ permil (table 1, Kent-Corson and others, 2006) as high-altitude catchments began draining through the basin. At about the same time, the mean $\delta^{18} \mathrm{O}_{\text {calcite }}$ values downstream in Lake Gosiute decrease by $\sim 6$ permil in the span of $100 \mathrm{kyr}$ (Carroll and others, 2008). Water spilling south from the newly freshened Lake Gosiute into the Piceance Creek Basin caused mean $\delta^{18} \mathrm{O}_{\text {calcite }}$ values in the latter to decrease by $\sim 1.2$ permil as the combined (and terminal) Lake Uinta equilibrated with the increased volume of $10 w-\delta{ }^{18} \mathrm{O}$ water flowing in from the north (fig. 3, Tgp above $\boldsymbol{m}$ ). Owing to the persistent connection with the Piceance Creek Basin, mean $\delta^{18} \mathrm{O}_{\text {calcite }}$ values in the Uinta Basin increase by $\sim 2$ permil (matching time-equivalent samples from the Piceance Creek Basin) and display less variability (table 1, fig. 3, Davis and others, 2008). As expected of a terminal lake, $\delta^{13} \mathrm{C}_{\text {calcite }} \delta^{18} \mathrm{O}_{\text {calcite }}$ values covary in samples from both the Uinta and Piceance Creek Basins (table 1 and fig. 6, panels $\mathbf{T g} \boldsymbol{p}$ and $\boldsymbol{T} \boldsymbol{u} / \boldsymbol{T g t}$ ), and $\mathrm{Sr} / \mathrm{Ca}$ ratios are similarly high (table 1 and fig. 3). 
With the capture of catchments draining the Challis and Absaroka volcanic fields in the northern Cordillera, ${ }^{87} \mathrm{Sr} /{ }^{86} \mathrm{Sr}$ ratios of samples from Greater Green River Basin decrease to a mean of $\sim 0.7116$ after $\sim 49 \mathrm{Ma}$ (Carroll and others, 2008) likely due to the less radiogenic composition of the volcanic rocks (from 0.704-0.709, see table A6). As this water spilled south, a corresponding shift is seen in ${ }^{87} \mathrm{Sr} /{ }^{86} \mathrm{Sr}$ ratios of Piceance Creek Basin samples, from $\sim 0.7119$ at $\sim 51$ Ma to $\sim 0.7109$ at $48.6 \mathrm{Ma}$ (fig. 3A). Upsection, ${ }^{87} \mathrm{Sr} /{ }^{86} \mathrm{Sr}$ ratios continue to decrease over $\sim 150 \mathrm{~m}$ to $\sim 0.7102$ (fig. 3A). In the Uinta Basin, the sparsity of analyzed samples reveal only end members of what we infer to be a similarly decreasing trend in ${ }^{87} \mathrm{Sr} /{ }^{86} \mathrm{Sr}$ ratios, from a maximum of 0.7122 near the Mahogany marker to mean values of 0.7100 at $\sim 46 \mathrm{Ma}$ (fig. 3B). Although the initial decrease in ${ }^{87} \mathrm{Sr} /{ }^{86} \mathrm{Sr}$ ratios likely reflects the influence of new, less radiogenic catchments, there are several reasons to think that the continuing decline of ${ }^{87} \mathrm{Sr} /{ }^{86} \mathrm{Sr}$ ratios after $\sim 46 \mathrm{Ma}$ may mark decreasing inflows from the Greater Green River Basin. First, unlike ${ }^{87} \mathrm{Sr} /{ }^{86} \mathrm{Sr}$ ratios measured in lacustrine carbonates of both the Piceance Creek and Uinta Basins, those from the Greater Green River Basin never fall below 0.711. Second, mean ${ }^{87} \mathrm{Sr} /{ }^{86} \mathrm{Sr}$ ratios in both the Piceance Creek and Uinta Basins after 48.6 Ma are $\sim 0.710$, statistically indistinguishable from the ratios of older lacustrine rocks deposited when the same basins contained open lakes that drained west and north (table 1 and fig. 3A, $\boldsymbol{T} \boldsymbol{g}$ and $\boldsymbol{T} \boldsymbol{g c}$ ). Third, marginal lacustrine sediments of the upper Washakie Formation deposited in the Greater Green River Basin after $47 \mathrm{Ma}$ regress northward (Roehler, 1973, fig. 2), suggesting that a lingering deposystem in the Sand Wash sub-basin either drained internally or from a different outlet away from the Piceance Creek Basin. Fourth, the progradation of volcaniclastic sediments into the easternmost Uinta Basin (the Uinta Formation) tapers off between $\sim 47$ to $46 \mathrm{Ma}$ (Prothero, 1990, 1996; Smith and others, 2008a). Finally, growth structures observed in synorogenic deposits of the Duchesne River Formation in the northern Uinta Basin reveal active tectonism of the Uinta Uplift as late as $\sim 40$ Ma (Anderson and Picard, 1974; see also Stucky and others, 1996), which may have interfered with the connection between the Greater Green River and Piceance Creek Basins (Davis and others, 2008).

Detrital zircon data (fig. 4) suggest a growing contribution of Grenville(1315-1000 Ma) and Paleoproterozoic-age (1615-1800 Ma) grains to the Piceance Creek Basin over Eocene time. This trend is consistent with both large-scale axial drainage integration of the foreland and recycling of easily-eroded Mesozoic sediments that were progressively exposed along the flanks of rising Laramide uplifts (for example, Dickinson and Gehrels, 2003; Carroll and others, 2006; Smith and others, 2008b).

Piceance Creek Basin samples abruptly shift to ${ }^{87} \mathrm{Sr} /{ }^{86} \mathrm{Sr}$ ratios as low as 0.7080 in the Uinta Formation and lower tongues of the Green River Formation before returning to 0.7106 in two samples from the upper tongues (fig. 3A). We are not certain how to interpret the lowest observed values, but offer two possible explanations: As the lake in the Piceance Creek Basin contracted and shallowed, the depocenter may have become segmented, with some areas dominated by localized catchments draining easily weathered rocks with low ${ }^{87} \mathrm{Sr} /{ }^{86} \mathrm{Sr}$ (that is, Paleozoic carbonates). As an analog, when Pleistocene Lake Gunnison became discrete from Lake Bonneville, the ${ }^{87} \mathrm{Sr} /{ }^{86} \mathrm{Sr}$ ratio of its waters was identically low-0.708 (Oviatt, 1988; Hart and others, 2004). Another possibility regards the presence of substantial volcaniclastic grains contained in the carbonates with the lowest ${ }^{87} \mathrm{Sr} /{ }^{86} \mathrm{Sr}$ ratios. Though our method should prevent contamination by $\mathrm{Sr}^{2+}$ derived from the siliclastic component, it is possible that dissolution of these sediments in the depositional environment affected the Sr isotope composition of precipitating carbonate. 


\section{Demise of the Green River Lakes (early and late Middle Eocene)}

Lacustrine deposition in the Greater Green River Basin ended $\sim 48 \mathrm{Ma}$, overwhelmed by volcaniclastic alluvium that thereafter prograded southward into the Piceance Creek Basin (fig. 2, Surdam and Stanley, 1980; Smith and others, 2008a). The Piceance lake responded just as Lake Gosiute had before, freshening and increasingly passing water west into the Uinta Basin, which may have in turn periodically overspilled south into the Flagstaff Basin (fig. 2, Surdam and Stanley, 1980; Smith and others, 2008a; Davis and others, 2009). By $\sim 47 \mathrm{Ma}$, accommodation in both the Greater Green River and Piceance Creek Basins was depleted (Franczyk and others, 1992; Hail, 1992).

Although large-scale integration of axial drainage was probably disrupted by Late Laramide topographic growth of the Uinta Uplift, evaporative lakes in the Uinta and Flagstaff Basins persisted as terminal sinks within the foreland until $\sim 45$ and $43 \mathrm{Ma}$, respectively (Smith and others, 2008a; Davis and others, 2009). It has been suggested that the later demise of these lakes nonetheless conforms to the pattern of evolving Cordilleran drainage, driven by the expansion of distal catchments in tectonically and magmatically active areas of the hinterland (Davis and others, 2009). Although lacustrine deposition ended in the smaller Flagstaff Basin at $\sim 45 \mathrm{Ma}$, presumably for lack of accommodation, Lake Uinta freshened and infilled between $\sim 45$ and $43.1 \mathrm{Ma}$, coeval with the southward migration of hinterland magmatism into northeastern Nevada, where paleorivers flowed east to the Uinta Basin (that is, Copper Basin and Tuscarora volcanics, Christensen and Yeats, 1992; Henry, 2008).

Isotopic and elemental data record the changes in basin hydrology as the Green River lakes disappeared. Between $\sim 49$ and $\sim 48 \mathrm{Ma}$, samples from the vanishing Lake Gosiute (table 1, $\boldsymbol{u l}$ ) give a mean $\delta^{18} \mathrm{O}_{\text {calcite }}$ value of 22.0 permil (fig. 7, panel $49 \mathrm{Ma}$ ). Between $\sim 48$ and $\sim 47 \mathrm{Ma}$, as volcaniclastic sediment filled accommodation in the Piceance Creek Basin and its lake freshened, mean $\delta{ }^{18} \mathrm{O}_{\text {calcite }}$ values decrease again by $\sim 5.1$ permil to a similar mean of 22.2 permil (table 1, figs. $3 \mathrm{~A}$ and 7 , panel $47 \mathrm{Ma}, \mathbf{T u}$ and $\boldsymbol{T g t}$ ). The cessation of distal inflows from the northern Cordilleran catchments to Lake Uinta between $\sim 47$ and $46 \mathrm{Ma}$ caused an increase in mean $\delta^{18} \mathrm{O}_{\text {calcite }}$ values and $\mathrm{Sr} / \mathrm{Ca}$ ratios to 28.8 permil $(1 \sigma=1.1, \mathrm{n}=35)$ and $3.3 \mathrm{mmol} / \mathrm{mol}(1 \sigma=0.7, \mathrm{n}=15)$, respectively (figs. 2, 3B, and $7, \boldsymbol{T g m b} / \boldsymbol{T g s}$ ). To the south, mean $\delta^{18} \mathrm{O}_{\text {calcite }}$ values in Flagstaff Basin sediments also increase slightly, perhaps reflecting the influence of Lake Uinta (table 1, Upper $\boldsymbol{T g}$ ).

The end of lacustrine deposition in the Flagstaff Basin at $\sim 45 \mathrm{Ma}$ is obscured by a brief period of erosion that seems to have removed isotopic evidence of the lake's final freshening (Davis and others, 2009). Uinta Basin samples do record the final stage of Lake Uinta between $\sim 44$ and $43.1 \mathrm{Ma}$ (fig. 3B, Tgsl), showing a $\sim 6$ permil decrease in $\delta^{18} \mathrm{O}_{\text {calcite }}$ values to $\sim 20$ permil and a $3 \mathrm{mmol} / \mathrm{mol}$ decrease in $\mathrm{Sr} / \mathrm{Ca}$ ratios to 1.1 $\mathrm{mmol} / \mathrm{mol}$ (Davis and others, 2009). ${ }^{87} \mathrm{Sr} /{ }^{86} \mathrm{Sr}$ ratios from Uinta Basin samples hold steady at $\sim 0.710$ during this time, a ratio consistent with inflows from hinterland catchments to the west (Davis and others, 2008; Gierlowski-Kordesch and others, 2008).

\section{Magmatism Sweeps South (late Middle Eocene-Late Eocene)}

Restoring Neogene extension of the Basin and Range, the hinterland of northeastern Nevada and northwestern Utah was situated roughly 100 to $200 \mathrm{~km}$ west of the Uinta Basin. Though exact basin geometries are difficult to reconstruct in light of subsequent extension and erosion, sizeable lakes were also present in that area during Eocene time, preserved as deposits of the Elko, White Sage and Sheep Pass Formations (Winfrey, 1960; Fouch, 1979; Wingate, 1983; Good, 
1987; Dubiel and others, 1996). Some studies have used these lacustrine rocks to document a phase of Eocene and Oligocene extension that immediately precedes the migration of magmatism through the region (Axen and others, 1993; Potter and others, 1995).

Isotopic data from these lakes is also important to the interpretation of Cordilleran drainage patterns. Mean $\delta^{18} \mathrm{O}_{\text {calcite }}$ values in the late Middle Eocene upper Elko and White Sage Formations are 22.4 permil and 19.8 permil, respectively (table 1 ). A $\sim 8.5$ permil decrease in mean $\delta{ }^{18} \mathrm{O}_{\text {calcite }}$ values between $\sim 45$ and $37 \mathrm{Ma}$ in the Elko Basin (table 1) has been interpreted as surface uplift related to the coeval magmatism in the region (Horton and others, 2004). As noted above, ash-filled paleovalleys in the Elko area indicate eastward paleoflow (Henry, 2008), such that the expansion and uplift of local catchments in the late Middle Eocene would likely have influenced the hydrology and isotopic composition of Lake Uinta in the subjacent foreland (Davis and others, 2009).

The lake in the Claron Basin of southwest Utah, shallower and fresher than Lake Uinta in the late Middle Eocene, also records a decrease in mean $\delta^{18} \mathrm{O}_{\text {calcite }}$ values by 5.5 permil between $\sim 40$ and $35 \mathrm{Ma}$ (table 1), again interpreted as the effect of coeval uplift and drainage reorganization in northern Arizona (Elston and Young, 1991; Flowers and others, 2008; Davis and others, 2009). Interestingly, fluvial-lacustrine deposits to the east in the Galisteo Basin of central New Mexico remain more or less constant over the same period (table 1), suggesting differential uplift of the southeastern Colorado Plateau.

\section{Localized Depocenters (Late Eocene-Early Oligocene)}

By the post-Laramide Late Eocene, few large lakes remained anywhere in the Cordillera. Accommodation was primarily created through slow subsidence (compare, McMillan and others, 2006) while volcanism in the central and southern Cordillera (compare, Tintic, Marysvale, San Juan, Datil and Espinaso centers; see Lipman and others, 1972; Ingersoll and others, 1990) generated prodigious volcaniclastic sediments. As a result, depocenters were localized and fluvial (for example, the Brian Head Formation of the Claron Basin, the Bald Knoll and Dipping Vat Formations of the Flagstaff Basin, the Espinaso Formation of the Galisteo Basin). Outside of these depocenters, erosion dominated large regions of the Cordillera (for example, Epis and Chapin, 1975; Dickinson, 2004).

Isotopic and elemental data from this period are consistent with throughgoing rivers draining highstanding adjacent topography as well as the cooler and more arid climate prevailing in the Oligocene (for example, Wolfe, 1994; Zachos and others, 2001; Sheldon and Retallack, 2004). Mean $\delta^{18} \mathrm{O}_{\text {calcite }}$ values in sampled basins of Utah, Nevada and Montana are generally low (14-15\%o, table 1), resembling unevaporated, meteoric water possibly incorporating snowmelt (for example, Norris and others, 1996; Dettman and Lohmann, 2000). Mean values of samples from the Galisteo and Uinta Basins are 21.8 and 17.7 permil, respectively (table 1). Lack of evaporation is further indicated by $\delta^{18} \mathrm{O}_{\text {calcite }}-\delta^{13} \mathrm{C}_{\text {calcite }}$ values that do not covary in any of the basins (except weakly in the Galisteo Basin) and mean $\mathrm{Sr} / \mathrm{Ca}$ ratios that are everywhere $<0.5$ (table 1).

\section{CONCLUSIONS}

Isotopic and elemental composition of lacustrine carbonate samples from the Piceance Creek Basin of northwest Colorado record dramatic changes in basin hydrology during the Early and Middle Eocene. Interpreted alongside a large dataset of isotopic stratigraphies from sedimentary basins throughout the Paleogene Cordillera, the new data reflect the evolution of orogen-scale drainage 
patterns. Although changes in global and regional climate during the Paleogene undoubtedly influenced the Cordilleran paleoenvironment, the hydrology of neighboring basins in some cases trended in opposite directions, defying explanation by changes in climate alone. Instead, the data suggest changes in Cordilleran hydrology were tectonically forced, as accommodation was first created and then dissected and filled by processes of downwarping, uplift, and magmatism.

1. During the transition from thin-skinned Sevier-style thrusting to thick-skinned Laramide-style deformation during the Late Cretaceous and Paleocene, large river systems flowed east from the highstanding hinterland through the foreland and out to the ancestral Great Plains. Isotopic and elemental data substantiate this hydrologic regime with relatively low values $(\sim 20 \%$ o $)$, minimal evidence of evaporation, and ${ }^{87} \mathrm{Sr} /{ }^{86} \mathrm{Sr}$ ratios in the central foreland (Utah) consistent with inflows of hinterland provenance.

2. By the earliest Eocene, downwarping of the foredeep and block uplifts further east impounded a system of large $\left(>10,000 \mathrm{~km}^{2}\right)$ freshwater lakes in the central foreland (the Green River Lakes of Wyoming, Utah and Colorado). $\delta^{18} \mathrm{O}_{\text {calcite }}$ values in these early lakes remain low, and lack of an evaporative signal supports their open hydrology. ${ }^{87} \mathrm{Sr} /{ }^{86} \mathrm{Sr}$ ratios continue to reflect hinterland catchments to the west.

3. At $\sim 52 \mathrm{Ma}$, the hydrology of foreland lakes became closed and waters that had formerly exited the Cordillera to the east were diverted axially to the terminal Piceance Creek Basin. $\delta^{18} \mathrm{O}_{\text {calcite }}$ values in the Green River Lakes rise to 25 permil or higher at this time and covary with $\delta^{13} \mathrm{C}_{\text {calcite }}$, and $\mathrm{Sr} / \mathrm{Ca}$ ratios also increase, all indicating internal drainage and attendant evaporation. A marked increase in the ${ }^{87} \mathrm{Sr} /{ }^{86} \mathrm{Sr}$ ratio of Piceance Creek and Uinta Basin lacustrine carbonate reflects the integration of foreland drainage.

4. Beginning $\sim 49 \mathrm{Ma}$, magmatism in the northern Cordillera (that is, the Challis and Absaroka volcanic fields) led to the capture of drainages heading in north-central Idaho by Lake Gosiute. The influx of water and sediment freshened and infilled the lake basin, and affected the downstream Piceance Creek and Uinta Basins in sequence. Late Laramide rise of the Uinta Uplift interrupted axial drainage in the foreland between 47 to 46 Ma. $\delta^{18} \mathrm{O}_{\text {calcite }}$ values in the Sage Creek and Greater Green River Basins record the drainage capture event as a 10 and 6 permil decrease, respectively, at $\sim 49 \mathrm{Ma} . \delta^{18} \mathrm{O}_{\text {calcite }}$ values in the Piceance Creek and Uinta Basins, joined by a Lake Uinta highstand, also record the event. ${ }^{87} \mathrm{Sr} /{ }^{86} \mathrm{Sr}$ ratios in each of the Green River Lakes decrease with the integration of catchments draining Tertiary volcanics. ${ }^{87} \mathrm{Sr} /{ }^{86} \mathrm{Sr}$ ratios in the Piceance Creek and Uinta Basins decline further as inflows from the Greater Green River Basin cease.

5. Filled in by volcaniclastics, sedimentation in the Piceance Creek Basin ended at $\sim 47 \mathrm{Ma}$. Yet the southward sweep of magmatism through the Cordillera had a similar effect on adjacent intraforeland basins: lakes in the Flagstaff and Uinta Basins freshened and infilled at $\sim 45$ and $43 \mathrm{Ma}$, respectively, coeval with magmatism in their catchments to the west in northern Nevada (that is, the Copper Basin and Tuscarora volcanics). $\delta^{18} \mathrm{O}_{\text {calcite }}$ values decrease in each of the Elko, Flagstaff and Uinta Basins during this time by 7 to 10 permil. Between $\sim 40$ and $37 \mathrm{Ma}$, drainage patterns in northern Arizona reverse, perhaps related to episodes of uplift and/or magmatism to the south in central Arizona and south-central New Mexico, and $\delta^{18} \mathrm{O}_{\text {calcite }}$ values in the downstream Claron Basin of southern Utah also decrease by 5.5 permil. 
6. The Late Eocene and Oligocene Cordillera was characterized by further magmatism and localized depocenters of throughgoing fluvial systems. $\delta^{18} \mathrm{O}_{\mathrm{cal}^{-}}$ cite values from throughout the Cordillera are low $(\sim 14-18 \%)$ and lack signs of evaporative enrichment, evidencing a cooler, more arid climate than previously in the Paleogene.

ACKNOWLEDGMENTS

We acknowledge the support of National Science Foundation grant EAR0609649 to C. P. Chamberlain and a Stanford University Earth Sciences McGee grant to S. J. Davis. We thank Trevor Dumitru, Joe Wooden, Frank Mazdab, and George Gehrels for assistance in the processing and analysis of geochronological samples, and Jim Sweeney for help in the laboratory. U-Pb analyses of detrital zircon samples at the Arizona LaserChron Center were supported in part by funding from National Science Foundation grant EAR-732436. The manuscript was much improved by discussions with Stephan Graham, Pete DeCelles and Jim Ingle, as well as thorough reviews by Greg Retallack, Jay Quade and Majie Fan.

Appendix A
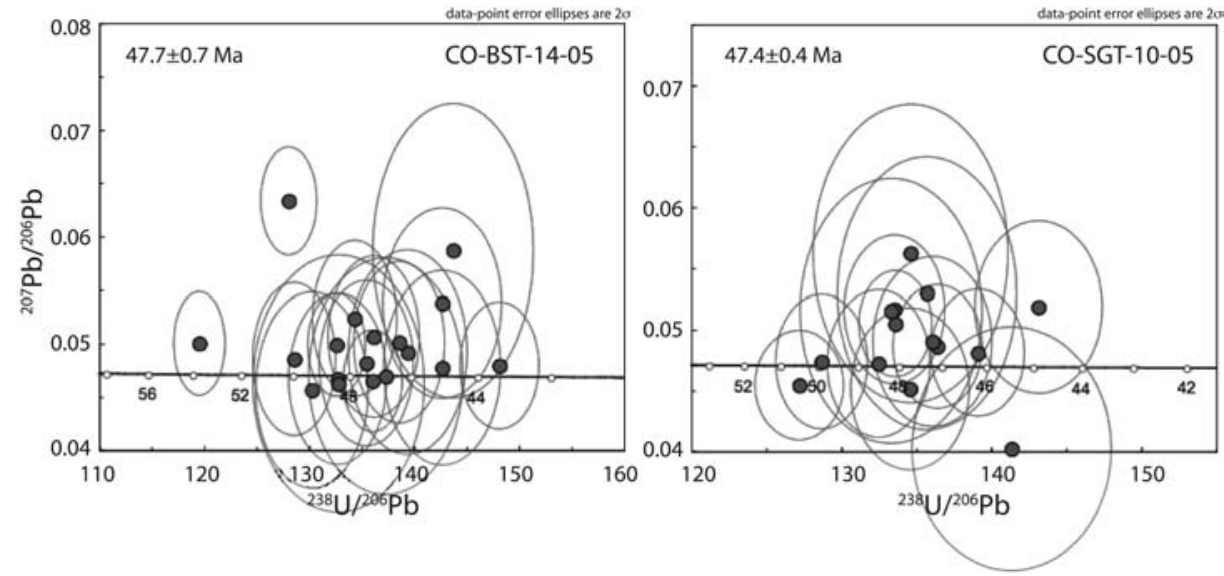

Fig. A1. Tera-Waserburg plots of U-Pb analyses of zircon separates from the Black Sulphur and Stewart Gulch Tongues (BST, SGT, respectively) of the Green River Formation in the Piceance Creek Basin. Samples represent coherent age groups that constrain maximum depositional age, and appear as \#4 and \#5, respectively, in figures 2 and 3 . 
TABLE A1

Details and key references of sampled exposures in the Piceance Creek

\begin{tabular}{|c|c|c|c|}
\hline Unit & Location Name & GPS Coordinates & Reference(s) \\
\hline Uinta Formation & Piceance Creek & $39^{\circ} 41.935^{\prime} \mathrm{N} 108^{\circ} 0.128^{\prime} \mathrm{W}$ & $\begin{array}{c}\text { Brobst and Tucker, } \\
1973\end{array}$ \\
\hline $\begin{array}{l}\text { Green River Formation } \\
\text { Jackrabbit Marl }\end{array}$ & Jackrabbit Ridge & $\begin{array}{c}\text { Type section } \\
\text { (between U.S. } 13 \text { and Stewart } \\
\text { Gulch): } \\
39^{\circ} 41.935^{\prime} \mathrm{N} 108^{\circ} 0.128^{\prime} \mathrm{W}\end{array}$ & O'Sullivan, 1987 \\
\hline Stewart Gulch Tongue & $\begin{array}{l}\text { Middle Fork of } \\
\text { Stewart Gulch }\end{array}$ & $\begin{array}{c}\text { Type section: } \\
39^{\circ} 43.884^{\prime} \mathrm{N} 108^{\circ} 10.065^{\prime} \mathrm{W}\end{array}$ & Hail, 1977 \\
\hline Coughs Creek Tongue & $\begin{array}{l}\text { West side of } \\
\text { Cow Creek }\end{array}$ & $\begin{array}{c}\text { Type section: } \\
39^{\circ} 42.634^{\prime} \mathrm{N} 107^{\circ} 59.887^{\prime} \mathrm{W}\end{array}$ & O'Sullivan, 1975 \\
\hline Black Sulphur Tongue & Black Sulphur Creek & $\begin{array}{c}\text { Type section: } \\
39^{\circ} 51.279 \mathrm{~N} 108^{\circ} 22.375^{\prime} \mathrm{W}\end{array}$ & $\begin{array}{c}\text { Duncan and others, } \\
1974\end{array}$ \\
\hline Dry Fork Tongue & $\begin{array}{l}\text { Near confluence of the } \\
\text { main stem and the Dry } \\
\text { Fork of Piceance } \\
\text { Creek }\end{array}$ & $\begin{array}{c}\text { Type section: } \\
40^{\circ} 00.481 \mathrm{~N} 108^{\circ} 14.385^{\prime} \mathrm{W}\end{array}$ & $\begin{array}{c}\text { Duncan and others, } \\
1974\end{array}$ \\
\hline Yellow Creek Tongue & $\begin{array}{l}\text { East side of } \\
\text { Yellow Creek }\end{array}$ & $\begin{array}{c}\text { Type section: } \\
40^{\circ} 5.119 \mathrm{~N} 108^{\circ} 20.082^{\prime} \mathrm{W}\end{array}$ & $\begin{array}{c}\text { Duncan and others, } \\
1974\end{array}$ \\
\hline Parachute Creek Member & Piceance Creek & $\begin{array}{c}\text { Complete section: } \\
39^{\circ} 41.935^{\prime} \mathrm{N} 108^{\circ} 0.128^{\prime} \mathrm{W}\end{array}$ & $\begin{array}{l}\text { Brobst and Tucker, } \\
1973\end{array}$ \\
\hline Garden Gulch Member & $\begin{array}{l}\text { West side of } \\
\text { Yellow Creek }\end{array}$ & $\begin{array}{c}\text { Type section: } \\
40^{\circ} 9.652 \mathrm{~N} 108^{\circ} 23.706^{\prime} \mathrm{W}\end{array}$ & Hail, 1990 \\
\hline Douglas Creek Member & Douglas Pass & $\begin{array}{l}\text { Principal reference section: } \\
39^{\circ} 36.209^{\prime} \mathrm{N} 108^{\circ} 46.847^{\prime} \mathrm{W}\end{array}$ & Johnson, 1984 \\
\hline $\begin{array}{l}\text { Long Point Bed / } \\
\text { Kimball Mountain Tuff Bed }\end{array}$ & & $\begin{array}{l}\text { Type section of Long Point Bed: } \\
39^{\circ} 26.338 \mathrm{~N} 108^{\circ} 0.294^{\prime} \mathrm{W}\end{array}$ & Johnson, 1984 \\
\hline Anvil Points Member & & $\begin{array}{l}\text { Type section of Long Point Bed: } \\
39^{\circ} 26.338 \text { N } 108^{\circ} 0.294^{\prime} \mathrm{W}\end{array}$ & Johnson, 1984 \\
\hline Cow Ridge Member & Cow Ridge & $\begin{array}{c}\text { Type section: } \\
39^{\circ} 23.641 \mathrm{~N} 108^{\circ} 22.388 \mathrm{~W}\end{array}$ & Johnson, 1984 \\
\hline
\end{tabular}


TAble A2

Isotopic and elemental compositions of samples

\begin{tabular}{|c|c|c|c|c|c|}
\hline Unit / Sample Number & $\begin{array}{c}\delta^{18} O_{\text {calcite }} \\
(\mathrm{V}-\mathrm{SMOW}) \\
\end{array}$ & $\begin{array}{l}\delta^{13} C_{\text {calcite }} \\
\text { (V-PDB) } \\
\end{array}$ & $\begin{array}{c}\mathrm{Sr} / \mathrm{Ca} \\
(\mathrm{mmol} / \mathrm{mol}) \\
\end{array}$ & ${ }^{87} \mathrm{Sr} /{ }^{86} \mathrm{Sr}_{\mathrm{i}}$ & $\begin{array}{c}\text { Stratigraphic } \\
\text { Position (m) } \\
\end{array}$ \\
\hline \multicolumn{6}{|l|}{$\begin{array}{l}\text { Uinta Formation / } \\
\text { Tongues of the Green }\end{array}$} \\
\hline \multicolumn{6}{|l|}{ River Formation } \\
\hline CO-YCT-06-13 & 18.09 & 1.14 & & & 621.0 \\
\hline CO-YCT-06-14 & 18.76 & 2.31 & & & 623.0 \\
\hline CO-YCT-06-15 & 22.88 & 3.95 & & & 625.0 \\
\hline CO-YCT-06-02 & 22.14 & 3.19 & & & 627.5 \\
\hline CO-YCT-06-03 & 22.44 & 2.62 & & & 631.6 \\
\hline CO-YCT-06-04 & 23.88 & 3.26 & & & 632.5 \\
\hline CO-YCT-06-05 & 24.09 & 3.98 & & & 635.0 \\
\hline CO-YCT-06-06 & 21.72 & 3.15 & & & 635.4 \\
\hline CO-YCT-06-07 & 20.83 & 2.07 & & & 635.8 \\
\hline CO-YCT-06-08 & 21.73 & 2.67 & & & 637.5 \\
\hline CO-YCT-06-09 & 19.06 & 1.90 & & 0.70918 & 637.9 \\
\hline CO-YCT-06-10 & 22.10 & 2.92 & & & 638.7 \\
\hline CO-YCT-06-11 & 18.74 & 1.37 & & & 641.7 \\
\hline CO-YCT-06-12 & 16.33 & -1.44 & & & 643.7 \\
\hline CO-DFT-06-02 & 20.50 & 2.95 & & & 645.0 \\
\hline CO-DFT-06-03 & 18.51 & 1.69 & & & 647.0 \\
\hline CO-DFT-06-04 & 20.29 & 3.07 & & & 650.0 \\
\hline CO-DFT-06-05 & 16.44 & 2.88 & & & 654.4 \\
\hline CO-DFT-06-07 & 16.60 & 7.51 & & & 658.0 \\
\hline CO-DFT-06-11 & 17.09 & 4.85 & & & 661.5 \\
\hline CO-DFT-06-12 & 24.24 & 3.63 & & & 664.0 \\
\hline CO-DFT-06-13 & 23.16 & 3.45 & & & 665.1 \\
\hline CO-DFT-06-14 & 22.20 & 3.26 & & & 665.8 \\
\hline CO-DFT-06-15 & 22.71 & 3.63 & & & 666.2 \\
\hline CO-DFT-06-16 & 22.08 & 4.16 & & & 666.6 \\
\hline CO-DFT-06-17 & 25.90 & 4.01 & & & 667.3 \\
\hline CO-DFT-06-18 & 18.96 & 3.57 & & & 668.0 \\
\hline CO-DFT-06-21 & 17.74 & 1.72 & & 0.70803 & 671.3 \\
\hline CO-BST-06-05 & 17.14 & -5.21 & 2.65 & & 690.0 \\
\hline CO-BST-06-06 & 15.03 & -1.00 & 1.49 & & 692.9 \\
\hline CO-BST-06-07 & 13.05 & -5.21 & 3.37 & & 692.9 \\
\hline CO-BST-06-08 & 15.36 & -4.24 & 2.39 & & 693.7 \\
\hline CO-BST-06-10 & 25.74 & 6.15 & 2.66 & & 695.1 \\
\hline CO-BST-06-11 & 26.62 & 6.29 & 2.91 & & 695.5 \\
\hline CO-BST-06-12 & 15.92 & -13.26 & & & 696.5 \\
\hline CO-BST-06-13 & 18.85 & 1.56 & & 0.70802 & 696.9 \\
\hline CO-BST-06-15 & 16.73 & -8.23 & & & 698.0 \\
\hline CO-BST-06-16 & 20.01 & 3.46 & 1.49 & & 698.8 \\
\hline CO-BST-06-17 & 17.64 & 0.10 & & & 699.1 \\
\hline CO-BST-06-18 & 13.74 & -2.15 & & & 703.1 \\
\hline CO-CCT-06-02 & 18.80 & 5.76 & 3.52 & & 736.8 \\
\hline CO-CCT-06-04 & 27.47 & 8.39 & 2.39 & & 740.0 \\
\hline CO-CCT-06-05 & 27.48 & 8.79 & 3.00 & & 741.2 \\
\hline CO-CCT-06-06 & 26.68 & 7.66 & 2.30 & & 743.7 \\
\hline CO-CCT-06-07 & 26.52 & 8.04 & 2.83 & & 745.7 \\
\hline CO-CCT-06-08 & 27.76 & 8.58 & 2.70 & & 748.7 \\
\hline CO-CCT-06-09 & 27.19 & 8.23 & 3.23 & & 752.7 \\
\hline CO-CCT-06-10 & 26.82 & 8.54 & 2.37 & & 754.7 \\
\hline CO-CCT-06-12 & 27.01 & 8.19 & 2.77 & & 759.7 \\
\hline CO-CCT-06-13 & 24.06 & 5.60 & & & 761.2 \\
\hline CO-CCT-06-14 & 27.08 & 8.58 & 2.79 & & 763.2 \\
\hline CO-CCT-06-16 & 26.68 & 9.04 & 2.96 & 0.71083 & 766.8 \\
\hline
\end{tabular}


Table A2

(continued)

\begin{tabular}{|c|c|c|c|c|c|}
\hline Unit / Sample Number & $\begin{array}{c}\delta^{18} \mathbf{O}_{\text {calcite }} \\
(\mathrm{V}-\mathrm{S} M O W)\end{array}$ & $\begin{array}{l}\delta^{13} C_{\text {calcite }} \\
(V-P D B)\end{array}$ & $\begin{array}{c}\mathrm{Sr} / \mathrm{Ca} \\
(\mathrm{mmol} / \mathrm{mol})\end{array}$ & ${ }^{87} \mathrm{Sr}^{86} \mathrm{Sr}_{\mathrm{i}}$ & $\begin{array}{c}\text { Stratigraphic } \\
\text { Position (m) }\end{array}$ \\
\hline \multicolumn{6}{|l|}{ "Uinta Formation / } \\
\hline \multicolumn{6}{|l|}{ Tongues of the Green } \\
\hline \multicolumn{6}{|l|}{ River Formation } \\
\hline CO-СCТ-06-17 & 25.96 & 9.07 & 3.18 & & 772.2 \\
\hline CO-CCT-06-18 & 26.91 & 8.87 & 2.95 & & 776.2 \\
\hline CO-SGT-06-01 & 21.47 & 0.68 & & & 798.0 \\
\hline CO-SGT-06-03 & 24.28 & 4.71 & & 0.71039 & 800.0 \\
\hline CO-SGT-06-04 & 23.47 & 3.76 & & & 803.0 \\
\hline CO-SGT-06-05 & 22.03 & 1.59 & & & 804.1 \\
\hline CO-SGT-06-06 & 20.86 & 0.38 & & & 805.1 \\
\hline CO-SGT-06-07 & 21.68 & 0.78 & & & 806.6 \\
\hline CO-SGT-06-08 & 21.62 & 1.48 & & & 807.6 \\
\hline CO-SGT-06-09 & 22.23 & 1.10 & & & 808.6 \\
\hline CO-SGT-06-11 & 19.99 & 1.41 & & & 812.2 \\
\hline CO-SGT-06-14 & 26.98 & 6.45 & & & 813.2 \\
\hline CO-SGT-06-15 & 16.58 & -0.73 & & & 815.2 \\
\hline CO-SGT-06-16 & 22.18 & 0.96 & & & 817.2 \\
\hline CO-SGT-06-17 & 16.75 & 0.25 & & & 818.2 \\
\hline CO-SGT-06-20 & 26.34 & 7.75 & & & 800.0 \\
\hline CO-UF-06-01 & 27.53 & 8.88 & & & 566.4 \\
\hline CO-UF-06-02 & 24.61 & 6.53 & & & 568.4 \\
\hline CO-UF-06-04 & 26.82 & 7.67 & & 0.71030 & 571.9 \\
\hline CO-UF-06-05 & 23.59 & 5.57 & & & 572.4 \\
\hline CO-UF-06-06 & 20.31 & 3.79 & & & 575.4 \\
\hline CO-UF-06-07 & 23.12 & 3.69 & & & 580.4 \\
\hline CO-UF-06-08 & 23.42 & 4.86 & & & 585.4 \\
\hline CO-UF-06-11 & 15.91 & 1.61 & & 0.70854 & 599.4 \\
\hline CO-UF-06-12 & 19.82 & 3.40 & & & 603.4 \\
\hline CO-UF-06-13 & 20.36 & 4.27 & & & 605.4 \\
\hline CO-UF-06-14 & 19.23 & -0.92 & & & 609.4 \\
\hline \multicolumn{6}{|l|}{ Green River Formation } \\
\hline \multicolumn{6}{|l|}{ Garden Gulch Member } \\
\hline CO-GRGG-06-105 & 31.12 & 12.92 & 2.26 & & 51.7 \\
\hline CO-GRGG-06-104 & 32.40 & 12.44 & 3.35 & & 51.7 \\
\hline CO-GRGG-06-103 & 31.14 & 10.20 & 2.83 & & 51.7 \\
\hline CO-GRGG-06-01 & 19.31 & -10.81 & 0.33 & & 87.4 \\
\hline CO-GRGG-06-02 & 18.33 & -10.32 & 0.38 & & 106.5 \\
\hline CO-GRGG-06-03 & 23.03 & -1.84 & 1.30 & 0.71018 & 106.6 \\
\hline CO-GRGG-06-04 & 16.35 & -11.69 & 0.56 & & 122.5 \\
\hline CO-GRGG-06-05 & 17.62 & -8.81 & 0.52 & & 136.9 \\
\hline CO-GRGG-06-06 & 18.74 & -8.08 & 0.44 & & 138.5 \\
\hline CO-GRGG-06-07 & 18.84 & -4.36 & 0.60 & 0.71044 & 144.9 \\
\hline CO-GRGG-06-09 & 18.93 & -1.55 & 1.15 & & 153.6 \\
\hline CO-GRGG-06-10 & 14.65 & -18.91 & 1.07 & & 161.6 \\
\hline CO-GRGG-06-12 & 18.94 & -8.73 & 1.04 & & 177.6 \\
\hline CO-GRGG-06-13 & 17.08 & -15.07 & 1.31 & 0.71046 & 184.0 \\
\hline CO-GRGG-06-15 & 19.82 & -5.66 & 0.70 & & 196.0 \\
\hline CO-GRGG-06-16 & 22.10 & -1.70 & 1.42 & & 201.5 \\
\hline CO-GRGG-06-17 & 21.10 & -2.99 & 0.95 & 0.71038 & 203.1 \\
\hline CO-GRGG-06-20 & 22.12 & -0.66 & 0.86 & & 211.9 \\
\hline CO-GRGG-06-21 & 30.50 & 3.04 & 1.49 & & 219.9 \\
\hline CO-GRGG-06-22 & 28.16 & 3.05 & & & 223.1 \\
\hline CO-GRGG-06-23 & 28.80 & 3.63 & 2.02 & 0.71106 & 231.1 \\
\hline CO-GRGG-06-24 & 23.70 & 0.91 & 1.32 & & 239.1 \\
\hline CO-GRGG-06-25 & 27.56 & 4.92 & 1.71 & & 243.1 \\
\hline CO-GRGG-06-26 & 28.31 & 3.80 & 2.34 & & 249.4 \\
\hline CO-GRGG-06-27 & 27.86 & 3.89 & 1.76 & 0.71103 & 252.6 \\
\hline
\end{tabular}


Table A2

(continued)

\begin{tabular}{|c|c|c|c|c|c|}
\hline Unit / Sample Number & $\begin{array}{r}\delta^{18} \mathrm{O}_{\text {calcite }} \\
(\mathrm{V} \text {-SMOW) } \\
\end{array}$ & $\begin{array}{l}\delta^{13} \mathrm{C}_{\text {calcite }} \\
(\mathrm{V}-\mathrm{PDB}) \\
\end{array}$ & $\begin{array}{c}\mathrm{Sr} / \mathrm{Ca} \\
(\mathrm{mmol} / \mathrm{mol})\end{array}$ & ${ }^{87} \mathrm{Sr}^{86} \mathrm{Sr}_{\mathrm{i}}$ & $\begin{array}{c}\text { Stratigraphic } \\
\text { Position (m) } \\
\end{array}$ \\
\hline \multicolumn{6}{|l|}{ Green River Formation } \\
\hline \multicolumn{6}{|l|}{ Garden Gulch Member } \\
\hline CO-GRGG-06-28 & 28.71 & 2.49 & 2.27 & & 262.2 \\
\hline CO-GRGG-06-31 & 25.58 & 2.93 & 2.83 & & 281.4 \\
\hline \multicolumn{6}{|l|}{ Green River Formation } \\
\hline \multicolumn{6}{|l|}{ Parachute Creek Member } \\
\hline CO-GRPC-06-01 & 32.06 & 12.59 & 3.56 & & 211.9 \\
\hline CO-GRPC-06-101 & 14.58 & -1.86 & 1.46 & & 212.17 \\
\hline CO-GRPC-06-02 & 30.00 & 9.80 & 2.29 & 0.71144 & 245.7 \\
\hline CO-GRPC-06-03 & 31.41 & 14.37 & & & 265.9 \\
\hline CO-GRPC-06-05 & 32.29 & 15.00 & 1.53 & & 271.3 \\
\hline CO-GRPC-06-04 & 30.15 & 12.07 & 2.30 & 0.71188 & 271.3 \\
\hline CO-GRPC-06-06 & 31.32 & 14.34 & 1.85 & & 274.7 \\
\hline CO-GRPC-06-07 & 31.03 & 9.61 & 2.52 & & 280.1 \\
\hline CO-GRPC-06-08 & 31.82 & 10.93 & 2.76 & & 282.8 \\
\hline CO-GRPC-06-10 & 32.23 & 9.62 & 3.04 & & 307.1 \\
\hline CO-GRPC-06-11 & 33.02 & 12.82 & 2.42 & & 307.2 \\
\hline CO-GRPC-06-12 & 29.87 & 6.81 & 2.50 & & 315.3 \\
\hline CO-GRPC-06-13 & 29.78 & 8.26 & 2.26 & 0.71179 & 318.1 \\
\hline CO-GRPC-06-14 & 29.67 & 7.57 & & & 333.4 \\
\hline CO-GRPC-06-15 & 29.54 & 7.33 & 2.46 & & 340.2 \\
\hline CO-GRPC-06-17 & 29.22 & 4.53 & 4.15 & 0.71179 & 380.7 \\
\hline CO-GRPC-06-204 & 25.89 & 1.44 & 2.76 & & 396.8 \\
\hline CO-GRPC-06-201 & 26.70 & 4.20 & 3.25 & & 406.8 \\
\hline CO-GRPC-06-18 & 27.77 & 8.52 & 3.30 & 0.71105 & 432.2 \\
\hline CO-GRPC-06-19 & 29.71 & 10.24 & 3.00 & & 448.7 \\
\hline CO-GRPC-06-21 & 30.05 & 10.09 & 2.92 & & 449.5 \\
\hline CO-GRPC-06-20 & 25.49 & 5.63 & 2.28 & 0.71072 & 451.4 \\
\hline CO-GRPC-06-24 & 30.24 & 6.99 & 3.06 & & 471.1 \\
\hline CO-GRPC-06-25 & 28.27 & 6.32 & 3.25 & 0.71091 & 489.2 \\
\hline CO-GRPC-06-27 & 25.19 & 6.21 & 2.38 & & 513.0 \\
\hline CO-GRPC-06-29 & 26.57 & 7.09 & 2.62 & & 523.8 \\
\hline CO-GRPC-06-30 & 24.54 & 5.88 & 2.66 & & 529.2 \\
\hline CO-GRPC-06-31 & 25.95 & 5.94 & 2.56 & & 534.6 \\
\hline CO-GRPC-06-32 & 27.15 & 7.10 & 2.92 & & 540.0 \\
\hline CO-GRPC-06-33 & 27.43 & 7.17 & 2.68 & 0.71064 & 545.4 \\
\hline CO-GRPC-06-34 & 27.39 & 8.05 & 3.27 & & 550.8 \\
\hline CO-GRPC-06-35 & 24.32 & 6.01 & 2.75 & & 556.2 \\
\hline \multirow{2}{*}{\multicolumn{6}{|c|}{$\begin{array}{l}\text { Green River Formation } \\
\text { Douglas Creek Member }\end{array}$}} \\
\hline & & & & & \\
\hline CO-GRDC-06-29 & 31.47 & 4.28 & 4.20 & & 102.8 \\
\hline CO-GRDC-06-28 & 22.89 & -1.85 & 2.06 & & 106.8 \\
\hline CO-GRDC-06-27 & 22.04 & -3.34 & 1.88 & & 119.7 \\
\hline CO-GRDC-06-25 & 19.10 & -2.82 & 1.78 & 0.71055 & 180.4 \\
\hline CO-GRDC-06-22 & 22.13 & -0.94 & 4.49 & & 203.6 \\
\hline CO-GRDC-06-21B & 29.79 & 2.93 & 4.16 & & 224.3 \\
\hline CO-GRDC-06-21A & 29.88 & 2.19 & 3.51 & & 237.2 \\
\hline CO-GRDC-06-19 & & & & & 257.9 \\
\hline CO-GRDC-06-18 & 26.84 & -0.17 & 2.77 & 0.71133 & 273.4 \\
\hline CO-GRDC-06-15 & 28.86 & 2.43 & 4.38 & & 286.3 \\
\hline CO-GRDC-06-14 & 29.09 & 3.21 & 3.54 & & 294.0 \\
\hline CO-GRDC-06-13 & 27.52 & 1.65 & 2.84 & & 299.2 \\
\hline CO-GRDC-06-12 & 27.58 & 1.63 & 2.52 & & 306.9 \\
\hline CO-GRDC-06-11 & 28.81 & 2.54 & 2.34 & & 309.5 \\
\hline CO-GRDC-06-08 & 28.99 & 2.48 & 3.04 & & 319.8 \\
\hline CO-GRDC-06-09 & 28.54 & 2.30 & 3.14 & & 330.2 \\
\hline CO-GRDC-06-07 & 27.51 & 3.40 & 2.14 & & 345.7 \\
\hline CO-GRDC-06-06 & 28.25 & 3.94 & 3.03 & & 353.4 \\
\hline
\end{tabular}


Table A2

(continued)

\begin{tabular}{|c|c|c|c|c|c|}
\hline Unit / Sample Number & $\begin{array}{c}\delta^{18} \mathbf{O}_{\text {calcite }} \\
(\mathrm{V}-\mathrm{SMOW})\end{array}$ & $\begin{array}{l}\delta^{13} \mathrm{C}_{\text {calcite }} \\
(\mathrm{V}-\mathrm{PDB})\end{array}$ & $\begin{array}{c}\mathrm{Sr} / \mathrm{Ca} \\
(\mathrm{mmol} / \mathrm{mol})\end{array}$ & ${ }^{87} \mathrm{Sr} /{ }^{86} \mathrm{Sr}_{\mathrm{i}}$ & $\begin{array}{l}\text { Stratigraphic } \\
\text { Position (m) }\end{array}$ \\
\hline \multicolumn{6}{|l|}{ Green River Formation } \\
\hline \multicolumn{6}{|l|}{ Garden Gulch Member } \\
\hline CO-GRDC-06-02 & 28.30 & 4.11 & 3.35 & & 387.0 \\
\hline CO-GRDC-06-01 & 26.74 & 5.18 & 3.58 & & 394.8 \\
\hline \multicolumn{6}{|l|}{ Green River Formation } \\
\hline \multicolumn{6}{|l|}{ Anvil Points Member } \\
\hline CO-GRAP-06-102 & 18.70 & -11.63 & 0.30 & & 76.4 \\
\hline CO-GRAP-06-103 & 22.35 & -8.36 & 0.44 & & 81.4 \\
\hline CO-GRAP-06-101 & 20.32 & -2.79 & 0.75 & & 86.4 \\
\hline CO-LPB-06-01 & 25.46 & -13.11 & 1.13 & & 102.7 \\
\hline CO-LPB-06-02 & 24.27 & -8.02 & 0.92 & 0.71051 & 102.8 \\
\hline CO-GRAP-06-01 & 23.10 & -2.90 & 1.66 & & 133.0 \\
\hline CO-GRAP-06-02 & 14.39 & -2.65 & 1.69 & & 138.1 \\
\hline CO-GRAP-06-03 & 22.95 & -2.26 & & & 141.9 \\
\hline CO-GRAP-06-04 & 18.34 & -1.05 & 1.72 & 0.71049 & 145.7 \\
\hline CO-GRAP-06-05 & 22.41 & -2.79 & 1.72 & & 149.5 \\
\hline CO-GRAP-06-07 & 16.11 & -2.21 & & & 154.8 \\
\hline CO-GRAP-06-08 & 14.93 & -2.21 & 2.22 & & 157.3 \\
\hline CO-GRAP-06-10 & 13.52 & -2.29 & 1.89 & & 172.5 \\
\hline CO-GRAP-06-11 & 12.88 & -2.38 & 2.02 & & 177.5 \\
\hline CO-GRAP-06-12 & 16.23 & -1.75 & 1.69 & 0.71142 & 186.4 \\
\hline CO-GRAP-06-13 & 21.33 & -2.27 & & & 211.7 \\
\hline \multicolumn{6}{|l|}{ Green River Formation } \\
\hline \multicolumn{6}{|l|}{ Cow Ridge Member } \\
\hline CO-GRCR-06-01 & 21.42 & -6.93 & 1.37 & & 0 \\
\hline CO-GRCR-06-02 & 24.91 & -12.74 & & 0.71033 & 2 \\
\hline CO-GRCR-06-03 & 23.81 & -7.47 & & & 5 \\
\hline CO-GRCR-06-04 & 24.52 & -3.34 & 1.36 & 0.71015 & 6 \\
\hline CO-GRCR-06-05 & 24.71 & -1.44 & & & 8.5 \\
\hline CO-GRCR-06-06 & 22.64 & -3.60 & & 0.71026 & 9.7 \\
\hline CO-GRCR-06-07 & 19.80 & -8.60 & 0.59 & & 12.7 \\
\hline CO-GRCR-06-09 & 18.35 & -6.78 & & & 20.2 \\
\hline CO-GRCR-06-11 & 26.02 & -9.72 & & & 28.2 \\
\hline CO-GRCR-06-12 & 22.50 & -5.23 & & 0.71017 & 32.2 \\
\hline
\end{tabular}


Table A3

Age constraints of sampled units in the Piceance Creek Basin

\begin{tabular}{|c|c|c|c|c|}
\hline Unit & Reported Age & Method & Details & Reference(s) \\
\hline \multicolumn{5}{|c|}{ Green River Formation } \\
\hline \multicolumn{5}{|c|}{ Tongues } \\
\hline $\begin{array}{l}\text { Stewart Gulch } \\
\text { Tongue }\end{array}$ & $47.4 \pm 0.3 \mathrm{Ma}$ & $\begin{array}{l}\text { U-Pb Zircon } \\
\text { (SHRIMP-RG) }\end{array}$ & (\#5 in figs. 2 and 3 ) & this study \\
\hline $\begin{array}{l}\text { Black Sulphur } \\
\text { Tongue }\end{array}$ & $47.7 \pm 0.7 \mathrm{Ma}$ & $\begin{array}{l}\text { U-Pb Zircon } \\
\text { (SHRIMP-RG) }\end{array}$ & (\#4 in figs. 2 and 3 ) & this study \\
\hline \multicolumn{5}{|c|}{ Parachute Creek Member } \\
\hline Wavy Tuff & $48.37 \pm 0.23 \mathrm{Ma}$ & ${ }^{40} \mathrm{Ar}-{ }^{39} \mathrm{Ar}$ & $\begin{array}{c}\text { ( } 50 \mathrm{~m} \text { above Mahogany } \\
\text { Marker in Uinta Basin) } \\
\mathrm{N} 39^{\circ} 50^{\prime} 59.3^{\prime \prime} \\
\text { W } 110^{\circ} 15^{\prime} 17.5^{\prime \prime} \\
\text { (\#3 in figs. } 2 \text { and 3) }\end{array}$ & $\begin{array}{l}\text { Smith and others, } \\
2008\end{array}$ \\
\hline Curly Tuff & $49.02 \pm 0.30 \mathrm{Ma}$ & ${ }^{40} \mathrm{Ar}-{ }^{39} \mathrm{Ar}$ & $\begin{array}{l}\text { ( } 25 \text { m below Mahogany } \\
\text { Marker in Uinta Basin) } \\
\text { N } 39^{\circ} 50^{\prime} 33.8^{\prime \prime} \\
\text { W } 110^{\circ} 15^{\prime} 3.1^{\prime \prime} \\
\text { (\#2 in figs. } 2 \text { and } 3)\end{array}$ & $\begin{array}{l}\text { Smith and others, } \\
2008\end{array}$ \\
\hline Yellow Tuff & $51.24 \pm 0.52 \mathrm{Ma}$ & ${ }^{40} \mathrm{Ar}-{ }^{39} \mathrm{Ar}$ & 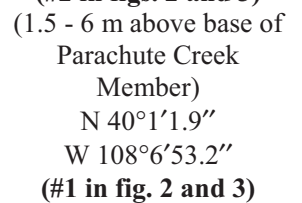 & $\begin{array}{l}\text { Pipiringos and } \\
\text { Johnson, 1975; } \\
\text { Smith and others, } \\
2008\end{array}$ \\
\hline
\end{tabular}




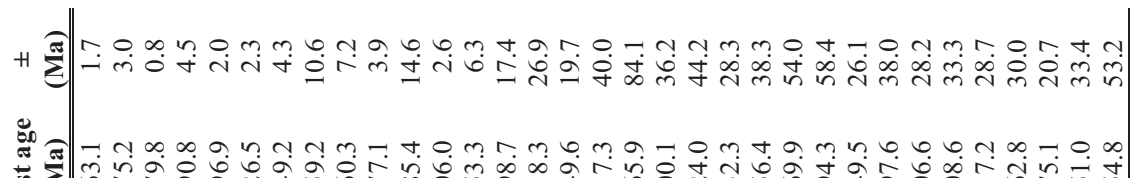

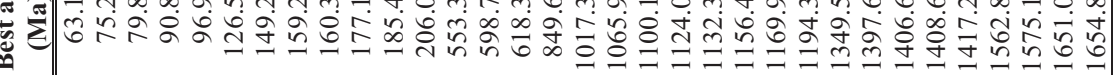

a

+

*

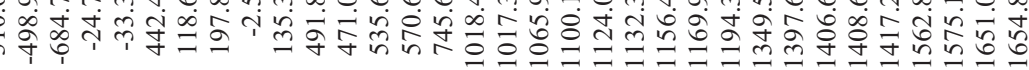

m-tr $\rightarrow$ t

*am n n

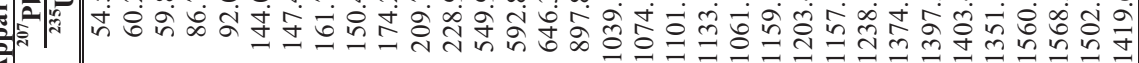

ส H

* * *

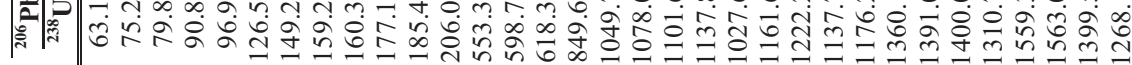
빈 1 H ब

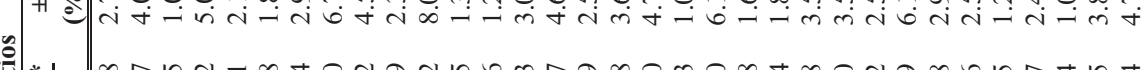

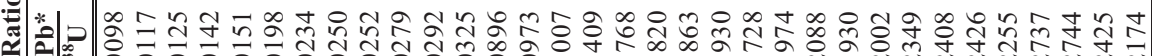
䑸

H

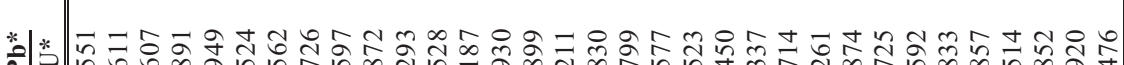

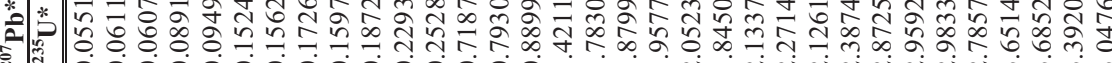

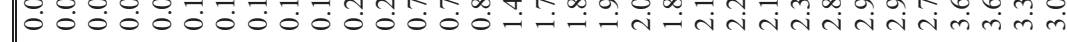

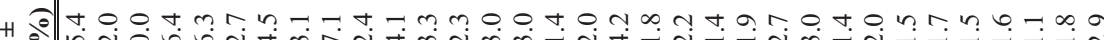
อ

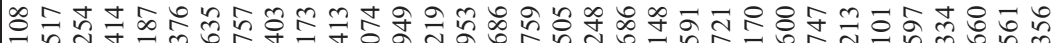

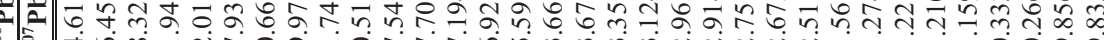

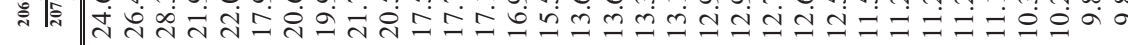
Dझ

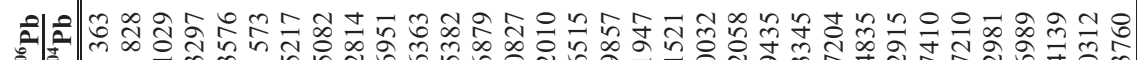

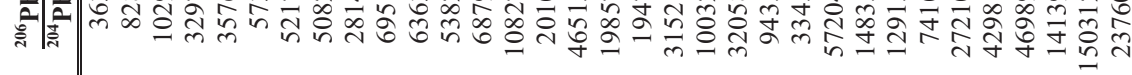

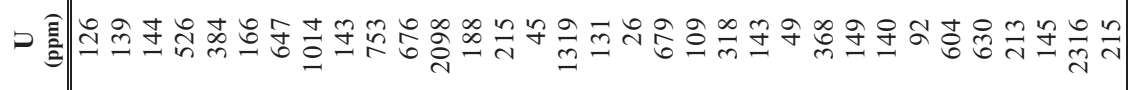

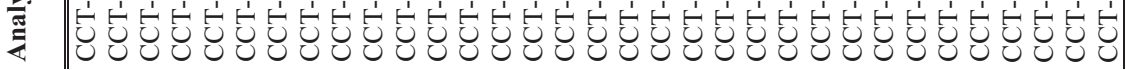




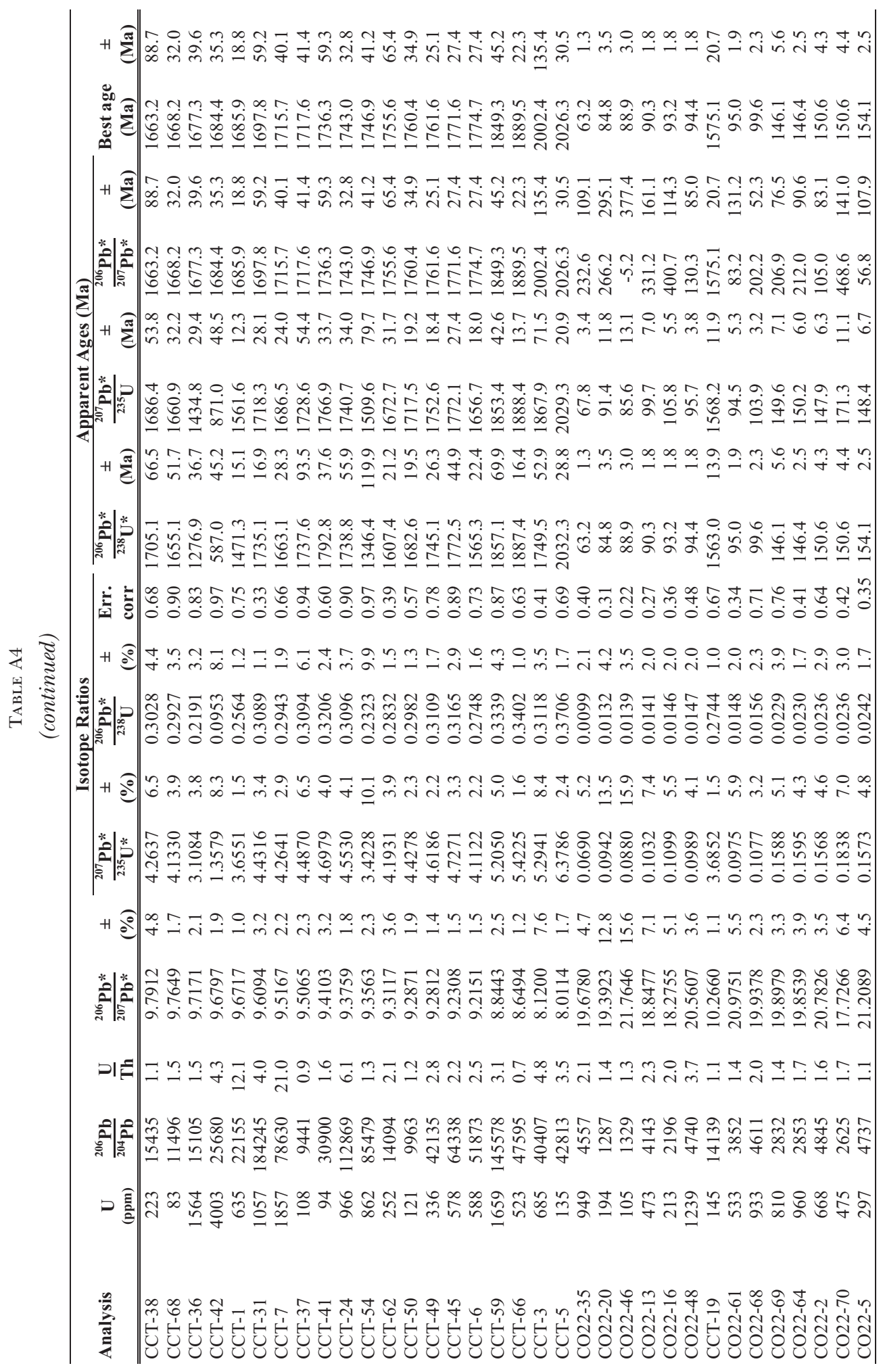




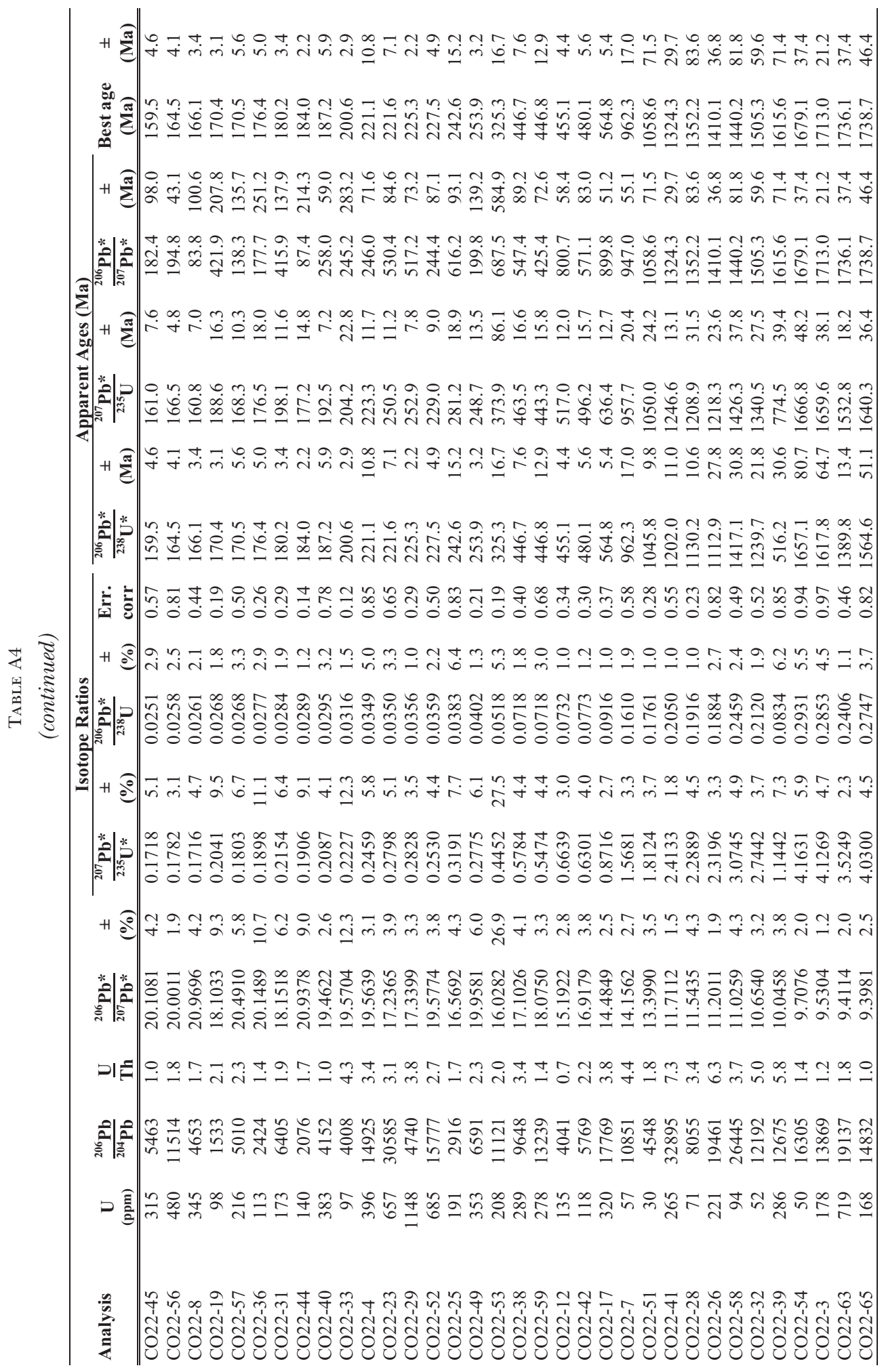




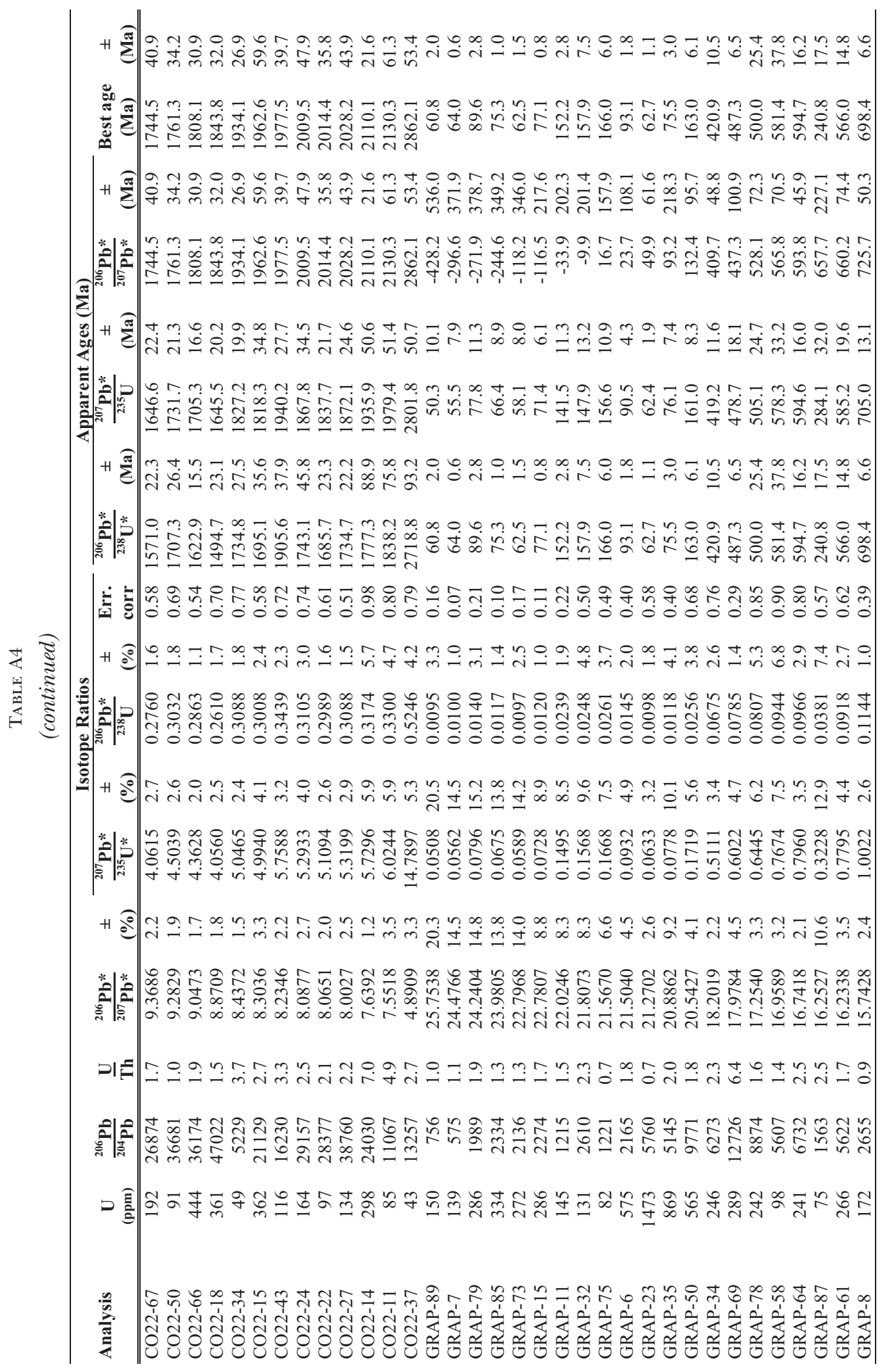




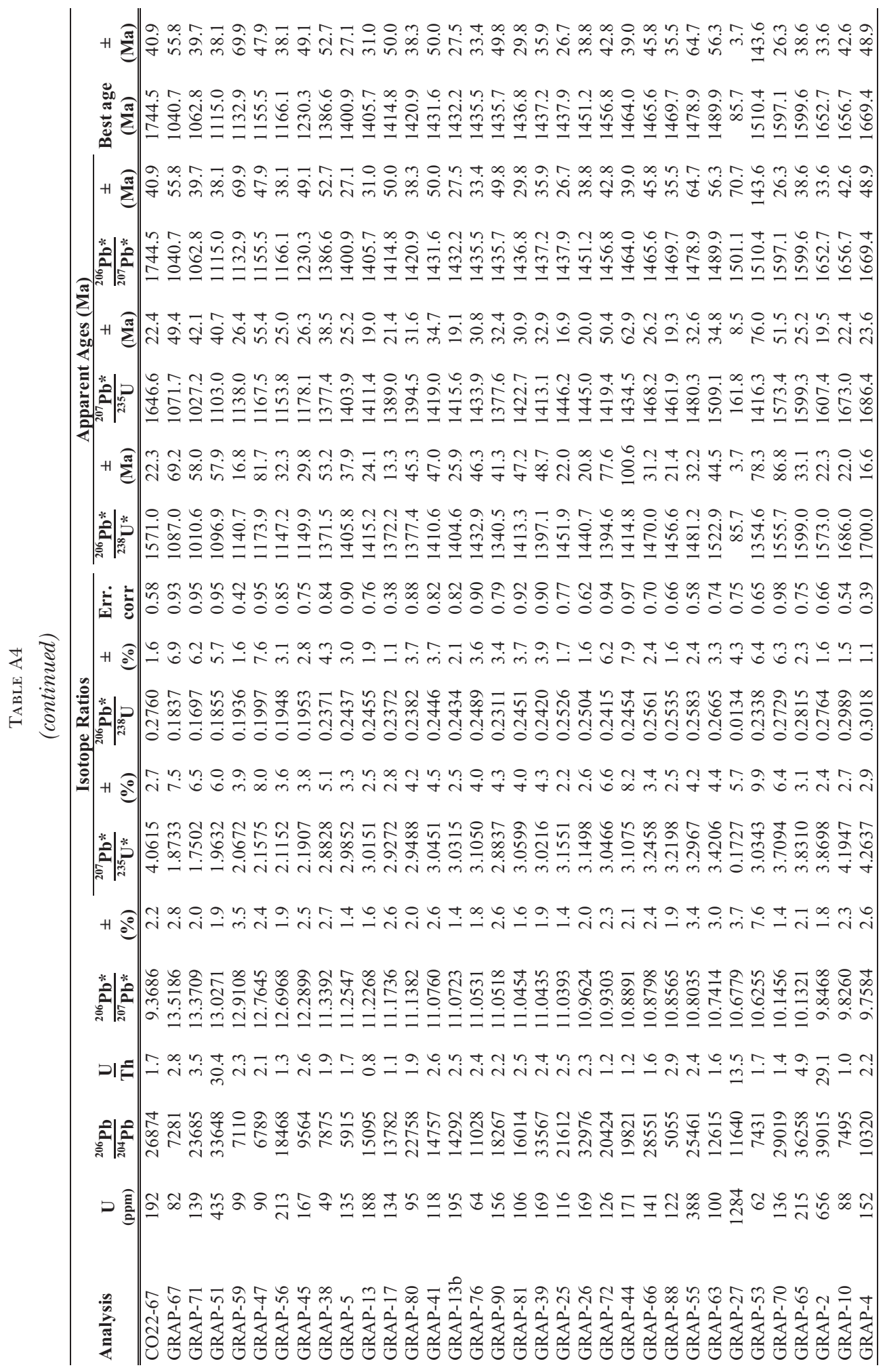




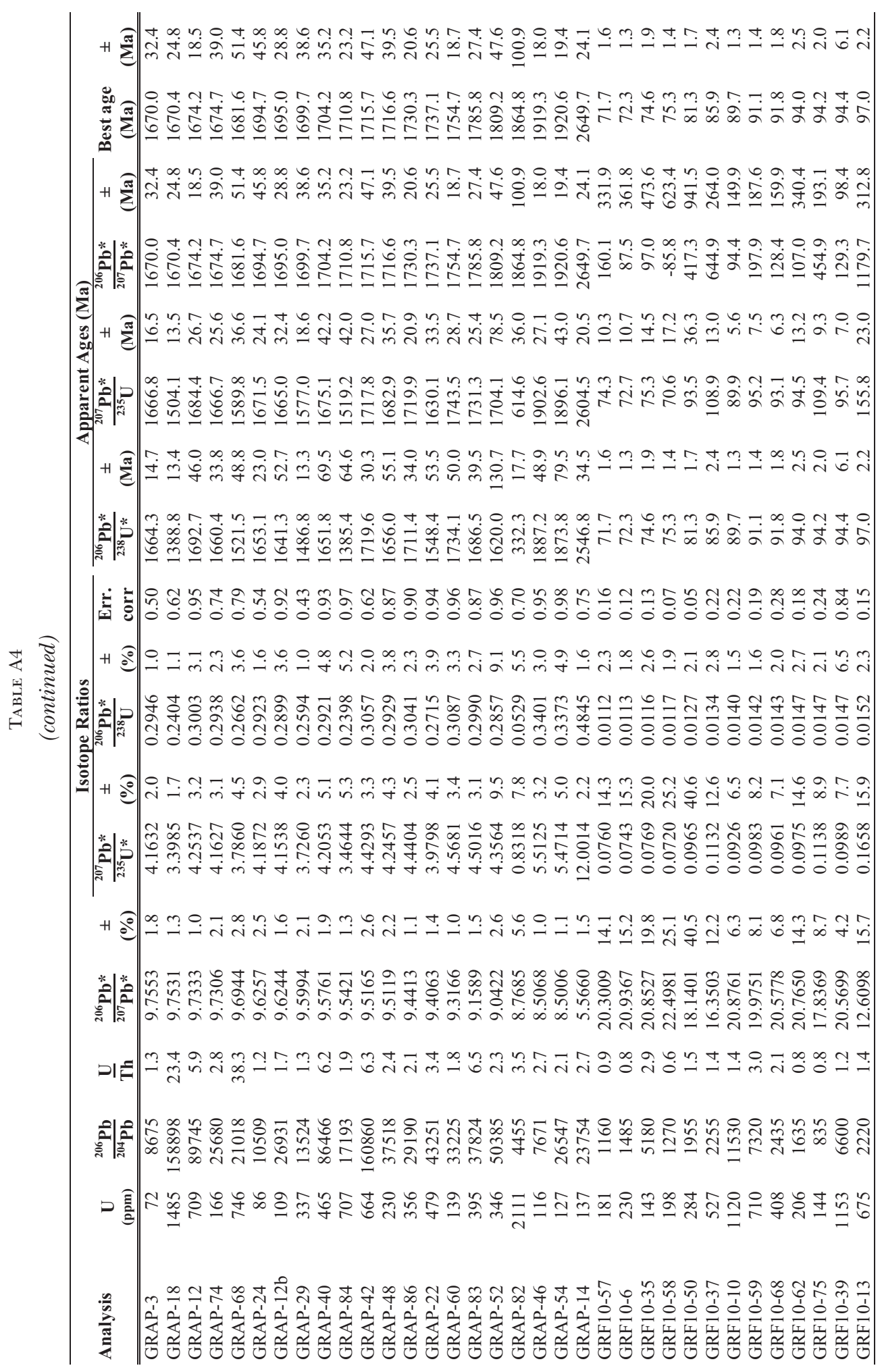




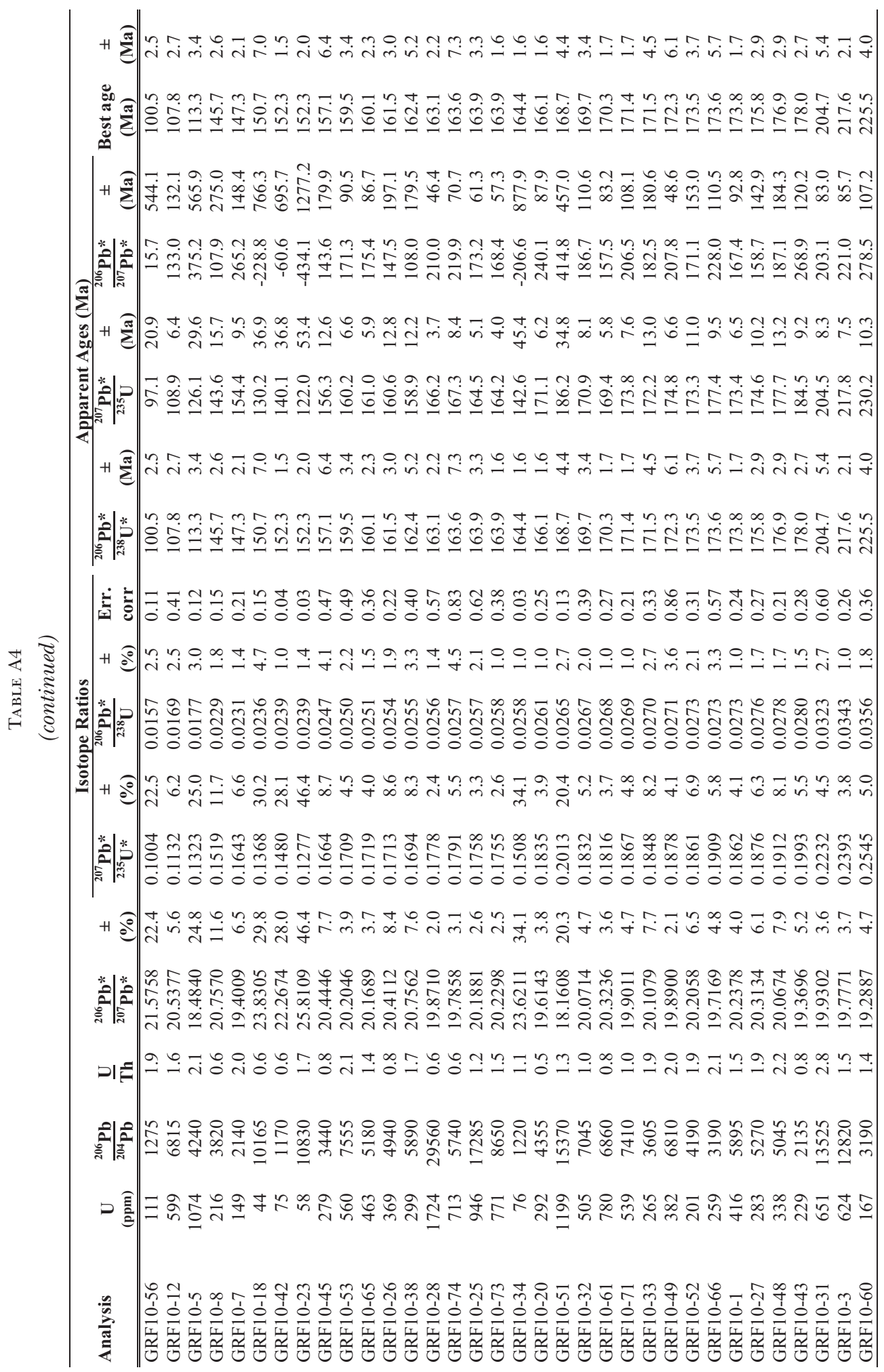




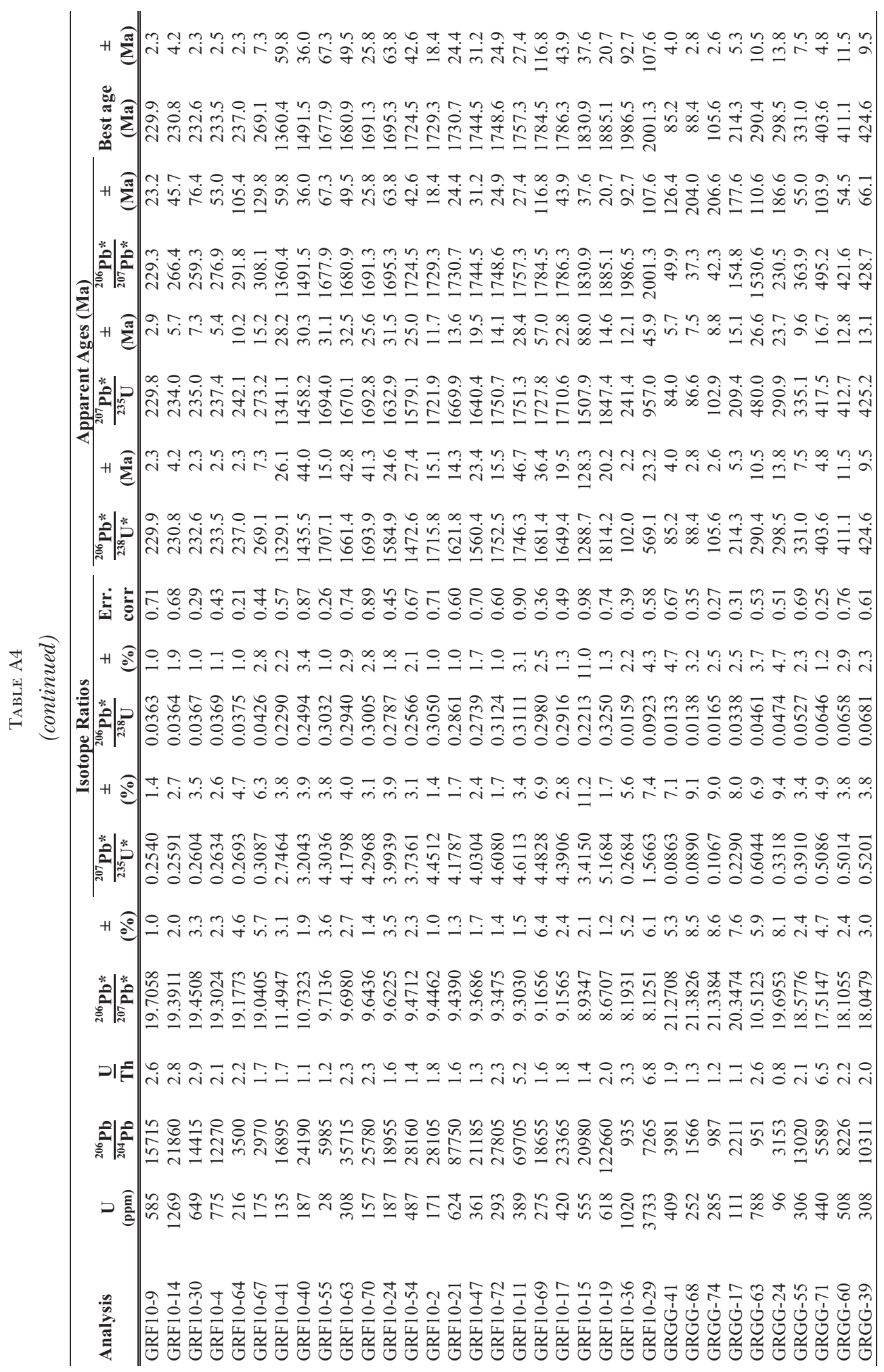




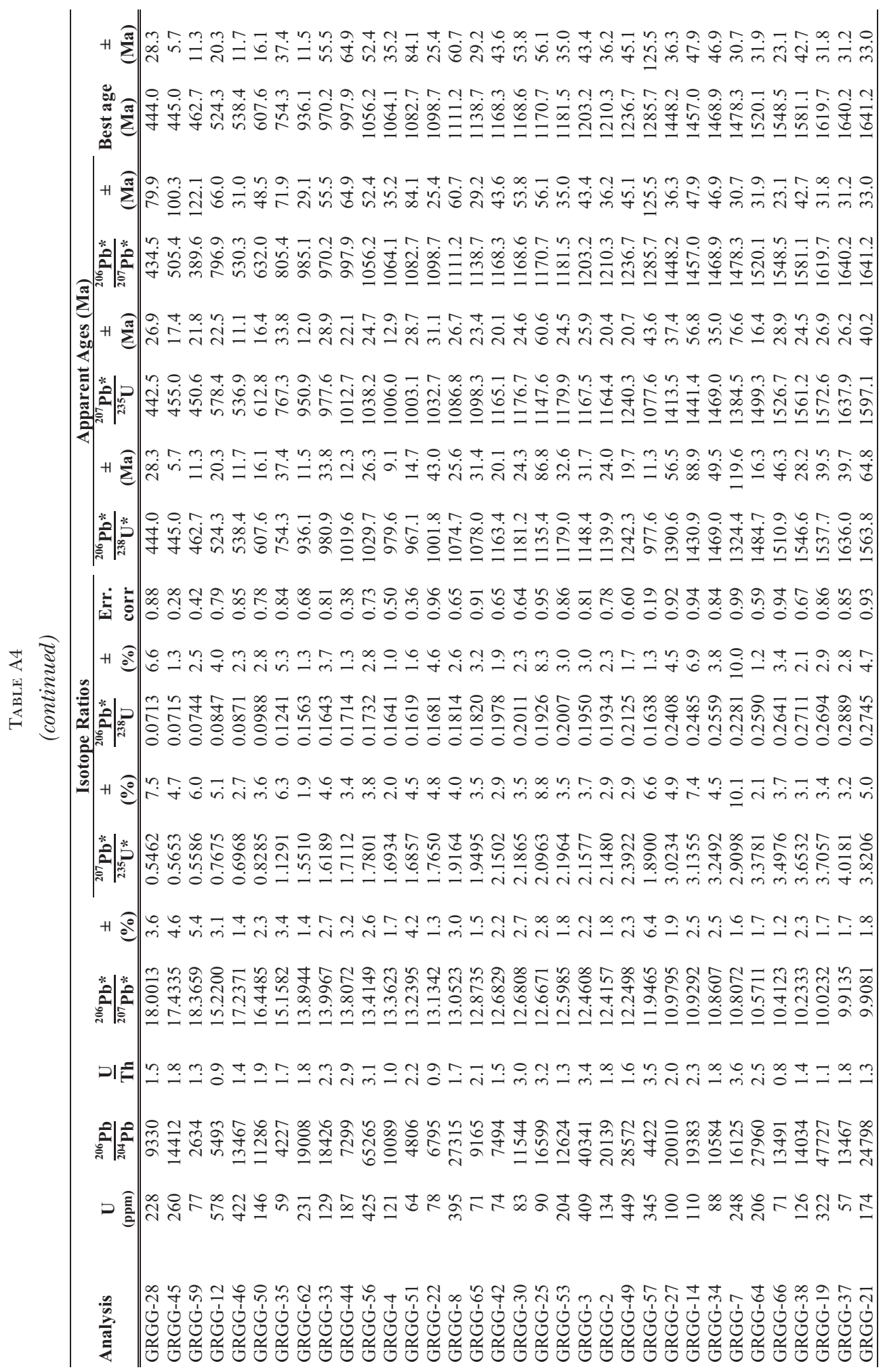




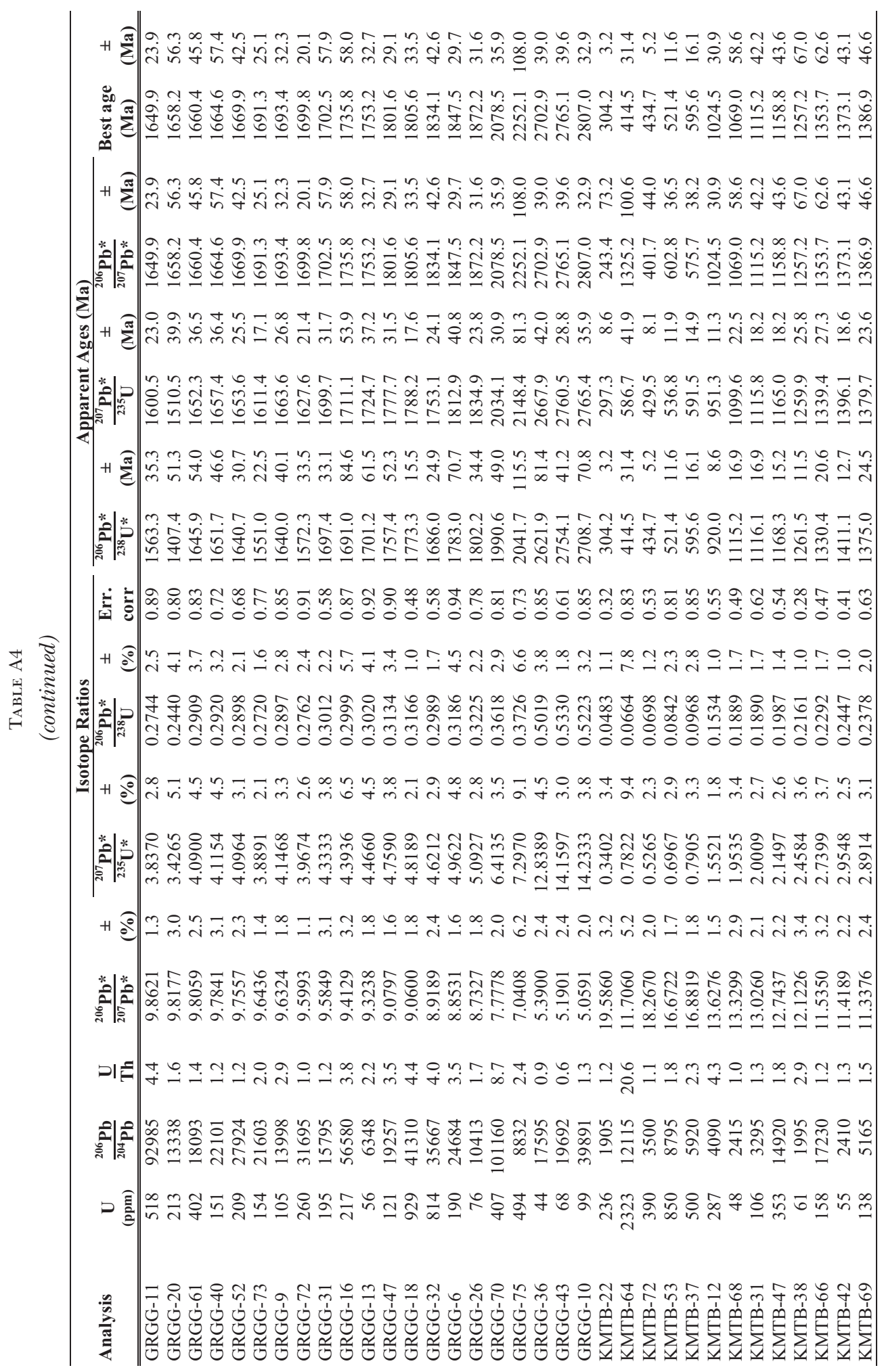


Table A4

(continued)

\begin{tabular}{|c|c|c|c|c|c|c|c|c|c|c|c|c|c|c|c|c|c|c|}
\hline \multirow[b]{2}{*}{ Analysis } & \multirow[b]{2}{*}{$\underset{(\mathbf{p p m})}{\mathbf{U}}$} & \multirow[b]{2}{*}{${ }^{206} \mathrm{~Pb}$} & \multirow[b]{2}{*}{$\frac{\mathrm{U}}{\mathrm{Th}}$} & \multirow[b]{2}{*}{$\frac{{ }^{206} \mathrm{~Pb}^{*}}{{ }^{207} \mathrm{~Pb}^{*}}$} & \multirow[b]{2}{*}{$\begin{array}{c} \pm \\
(\%)\end{array}$} & \multicolumn{5}{|c|}{ Isotope Ratios } & \multicolumn{6}{|c|}{ Apparent Ages (Ma) } & \multirow[b]{2}{*}{$\begin{array}{c}\text { Best age } \\
\text { (Ma) }\end{array}$} & \multirow[b]{2}{*}{$\begin{array}{c} \pm \\
\text { (Ma) } \\
\end{array}$} \\
\hline & & & & & & $\frac{{ }^{207} \mathbf{P b}^{*}}{{ }^{235} \mathbf{U}^{*}}$ & $\begin{array}{c} \pm \\
(\%)\end{array}$ & $\frac{{ }^{206} \mathbf{P b}^{*}}{{ }^{238} \mathbf{U}}$ & $\begin{array}{c} \pm \\
(\%)\end{array}$ & $\begin{array}{l}\text { Err. } \\
\text { corr }\end{array}$ & $\frac{{ }^{206} \mathrm{~Pb}^{*}}{{ }^{238} \mathrm{U}^{*}}$ & $\begin{array}{c} \pm \\
\text { (Ma) }\end{array}$ & $\frac{{ }^{2077} \mathbf{P b}^{*}}{{ }^{235} \mathbf{U}}$ & $\begin{array}{c} \pm \\
(\mathrm{Ma})\end{array}$ & $\frac{{ }^{206} \mathrm{~Pb}^{*}}{{ }^{207} \mathrm{~Pb}^{*}}$ & $\begin{array}{c} \pm \\
\text { (Ma) }\end{array}$ & & \\
\hline KMTB-58 & 106 & 21605 & 1.2 & 11.2625 & 1.3 & 2.8587 & 1.9 & 0.2335 & 1.4 & 0.74 & 1352.9 & 16.8 & 1371.1 & 14.0 & 1399.6 & 24.0 & 131399.6 & 24.0 \\
\hline КМТВ-29 & 105 & 5910 & 2.0 & 11.2007 & 1.7 & 3.0498 & 2.6 & 0.2478 & 2.0 & 0.76 & 1426.9 & 25.5 & 1420.2 & 20.1 & 1410.2 & 32.9 & 1410.2 & 32.9 \\
\hline KMTB-11 & 178 & 3670 & 2.2 & 11.1545 & 3.8 & 3.1010 & 3.9 & 0.2509 & 1.0 & 0.25 & 1443.0 & 12.9 & 1432.9 & 30.2 & 1418.1 & 72.7 & 1418.1 & 72.7 \\
\hline KMTB-50 & 119 & 5100 & 1.8 & 11.1473 & 2.2 & 2.7207 & 3.7 & 0.2200 & 3.0 & 0.80 & 1281.7 & 34.6 & 1334.1 & 27.6 & 1419.3 & 42.4 & 1419.3 & 42.4 \\
\hline KMTB-30 & 94 & 6450 & 1.8 & 11.1253 & 2.4 & 3.0244 & 2.6 & 0.2440 & 1.0 & 0.39 & 1407.6 & 12.6 & 1413.8 & 19.6 & 1423.1 & 45.3 & 1423.1 & 45.3 \\
\hline KMTB-46 & 158 & 9535 & 1.7 & 11.1250 & 1.1 & 3.0249 & 2.0 & 0.2441 & 1.7 & 0.84 & 1407.8 & 21.4 & 1413.9 & 15.3 & 1423.1 & 20.7 & 1423.1 & 20.7 \\
\hline KMTB-44 & 631 & 19245 & 1.7 & 11.1121 & 2.0 & 2.3885 & 4.7 & 0.1925 & 4.2 & 0.91 & 1134.9 & 44.1 & 1239.2 & 33.5 & 1425.3 & 38.0 & 1425.3 & 38.0 \\
\hline KMTB-45 & 257 & 8635 & 1.0 & 11.1083 & 2.4 & 3.0255 & 3.5 & 0.2438 & 2.5 & 0.72 & 1406.2 & 32.0 & 1414.1 & 26.8 & 1426.0 & 46.6 & 1426.0 & 46.6 \\
\hline KMTB-65 & 109 & 3400 & 2.2 & 11.1009 & 2.9 & 3.1870 & 3.3 & 0.2566 & 1.6 & 0.48 & 1472.4 & 21.2 & 1454.0 & 25.8 & 1427.3 & 55.7 & 1427.3 & 55.7 \\
\hline KMTB-27 & 282 & 9725 & 1.9 & 11.0838 & 2.7 & 3.1068 & 3.5 & 0.2497 & 2.3 & 0.64 & 1437.2 & 29.1 & 1434.4 & 27.2 & 1430.2 & 52.2 & 1430.2 & 52.2 \\
\hline КMTB-7 & 50 & 3005 & 1.4 & 11.0650 & 4.3 & 3.0452 & 4.8 & 0.2444 & 2.1 & 0.45 & 1409.4 & 27.0 & 1419.0 & 36.5 & 1433.5 & 81.6 & 1433.5 & 81.6 \\
\hline КМTB-34 & 594 & 27325 & 5.1 & 11.0227 & 1.7 & 2.7011 & 2.0 & 0.2159 & 1.0 & 0.50 & 1260.4 & 11.4 & 1328.8 & 14.9 & 1440.8 & 33.2 & 1440.8 & 33.2 \\
\hline KMTB-80 & 92 & 3125 & 1.6 & 11.0056 & 3.0 & 3.0421 & 4.0 & 0.2428 & 2.7 & 0.66 & 1401.3 & 33.8 & 1418.2 & 30.9 & 1443.7 & 57.7 & 1443.7 & 57.7 \\
\hline КМТВ-49 & 440 & 16140 & 0.9 & 10.9549 & 1.0 & 3.2176 & 2.2 & 0.2556 & 2.0 & 0.89 & 1467.5 & 26.2 & 1461.4 & 17.4 & 1452.5 & 19.4 & 452.5 & 19.4 \\
\hline KMTB-39 & 163 & 6155 & 1.2 & 10.9292 & 3.7 & 3.1244 & 4.1 & 0.2477 & 1.6 & 0.38 & 1426.4 & 20.0 & 1438.7 & 31.2 & 1457.0 & 71.3 & 1457.0 & 71.3 \\
\hline KMTB-32 & 434 & 19415 & 1.2 & 10.9213 & 1.1 & 3.1326 & 2.2 & 0.2481 & 1.9 & 0.85 & 1428.8 & 23.7 & 1440.7 & 16.7 & 1458.3 & 21.5 & 1458.3 & 21.5 \\
\hline KMTB-2 & 185 & 6245 & 3.6 & 10.9110 & 1.7 & 3.2753 & 2.1 & 0.2592 & 1.4 & 0.64 & 1485.7 & 18.0 & 1475.2 & 16.7 & 1460.1 & 31.4 & 1460.1 & 31.4 \\
\hline КМТВ-17 & 94 & 11935 & 1.3 & 10.9103 & 1.2 & 3.1846 & 2.3 & 0.2520 & 2.0 & 0.86 & 1448.8 & 25.4 & 1453.4 & 17.6 & 1460.3 & 21.9 & 1460.3 & 21.9 \\
\hline KMTB-55 & 150 & 10705 & 1.2 & 10.9049 & 1.8 & 3.0474 & 2.3 & 0.2410 & 1.4 & 0.61 & 1392.0 & 17.8 & 1419.6 & 17.7 & 1461.2 & 34.6 & 1461.2 & 34.6 \\
\hline КМТВ-74 & 279 & 9625 & 2.0 & 10.8802 & 1.9 & 3.1383 & 2.2 & 0.2476 & 1.1 & 0.52 & 1426.3 & 14.6 & 1442.1 & 17.0 & 1465.5 & 35.9 & 1465.5 & 35.9 \\
\hline КМТВ-19 & 679 & 56700 & 7.7 & 10.1193 & 2.3 & 3.7156 & 2.5 & 0.2727 & 1.0 & 0.40 & 1554.5 & 13.8 & 1574.7 & 20.1 & 1602.0 & 43.1 & 1602.0 & 43.1 \\
\hline KMTB-8 & 57 & 1665 & 1.6 & 10.0431 & 3.1 & 3.7193 & 4.4 & 0.2709 & 3.1 & 0.70 & 1545.4 & 42.6 & 1575.5 & 35.3 & 1616.1 & 58.4 & 1616.1 & 58.4 \\
\hline KMTB-82 & 283 & 11140 & 2.2 & 10.0336 & 2.0 & 3.0276 & 4.8 & 0.2203 & 4.4 & 0.91 & 1283.6 & 50.9 & 1414.6 & 36.7 & 1617.8 & 37.5 & 1617.8 & 37.5 \\
\hline КMTB-67 & 121 & 5800 & 1.0 & 10.0159 & 3.3 & 3.7003 & 3.4 & 0.2688 & 1.0 & 0.29 & 1534.7 & 13.7 & 1571.4 & 27.3 & 1621.1 & 60.6 & 1621.1 & 60.6 \\
\hline КМТВ-57 & 57 & 2130 & 1.6 & 9.9678 & 2.6 & 3.7833 & 2.8 & 0.2735 & 1.0 & 0.36 & 1558.6 & 13.8 & 1589.2 & 22.5 & 1630.1 & 48.6 & 1630.1 & 48.6 \\
\hline КМТВ-6 & 304 & 10255 & 4.3 & 9.8127 & 1.8 & 4.0931 & 2.0 & 0.2913 & 1.0 & 0.50 & 1648.0 & 14.5 & 1652.9 & 16.5 & 1659.2 & 32.4 & 1659.2 & 32.4 \\
\hline КМTB-73 & 203 & 22780 & 4.5 & 9.7774 & 1.3 & 3.9883 & 2.1 & 0.2828 & 1.7 & 0.79 & 1605.6 & 24.0 & 1631.8 & 17.3 & 1665.8 & 23.9 & 1665.8 & 23.9 \\
\hline КМТВ-48 & 93 & 7415 & 3.8 & 9.7260 & 1.2 & 4.2332 & 3.1 & 0.2986 & 2.9 & 0.92 & 1684.4 & 42.2 & 1680.5 & 25.5 & 1675.6 & 22.6 & 1675.6 & 22.6 \\
\hline КМТВ-79 & 88 & 5805 & 2.1 & 9.6820 & 2.1 & 4.2146 & 2.4 & 0.2960 & 1.0 & 0.42 & 1671.2 & 14.7 & 1676.9 & 19.4 & 1683.9 & 39.6 & 1683.9 & 39.6 \\
\hline KMTB-20 & 97 & 5160 & 2.9 & 9.6800 & 2.0 & 4.0450 & 2.7 & 0.2840 & 1.8 & 0.67 & 1611.4 & 25.4 & 1643.3 & 21.7 & 1684.3 & 36.7 & 1684.3 & 36.7 \\
\hline
\end{tabular}




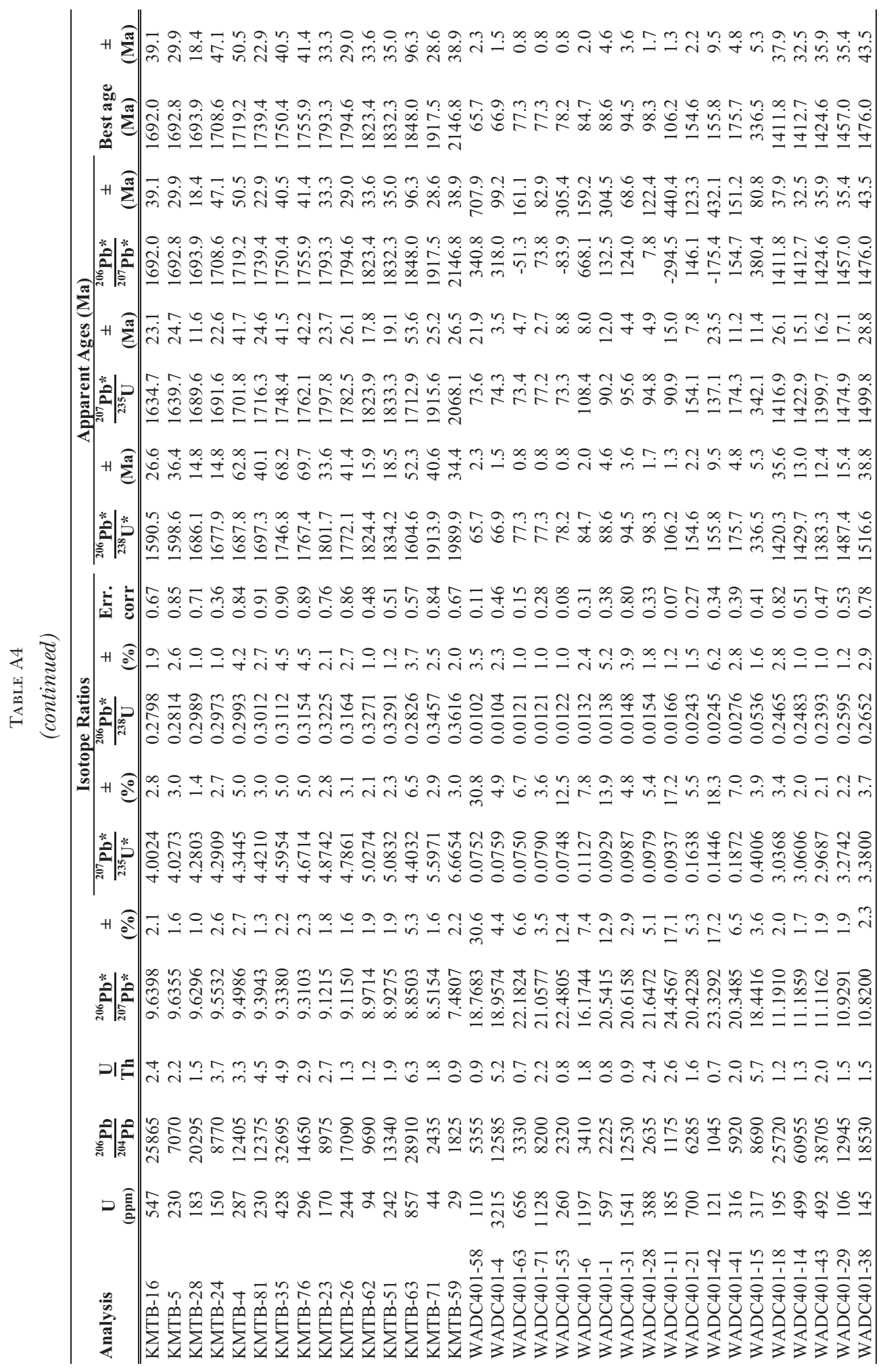




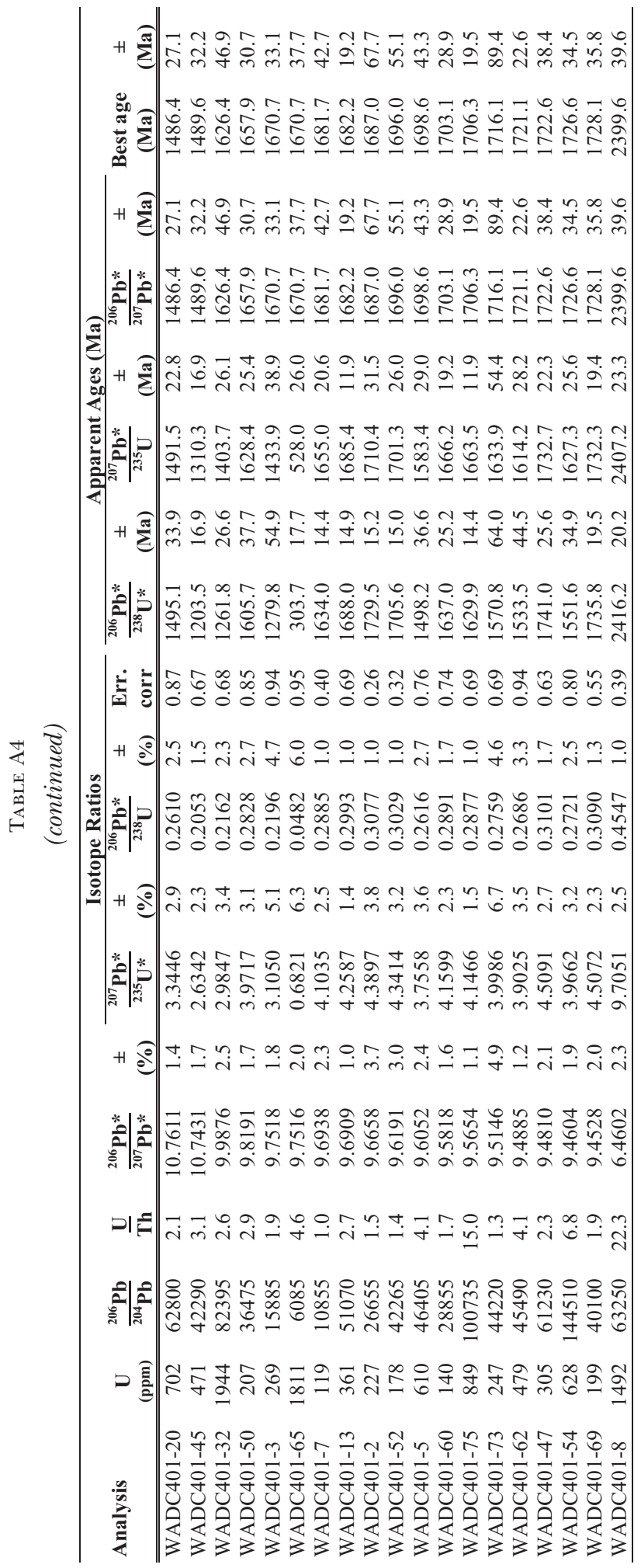


patterns: Isotope paleohydrology of sequential Laramide basins

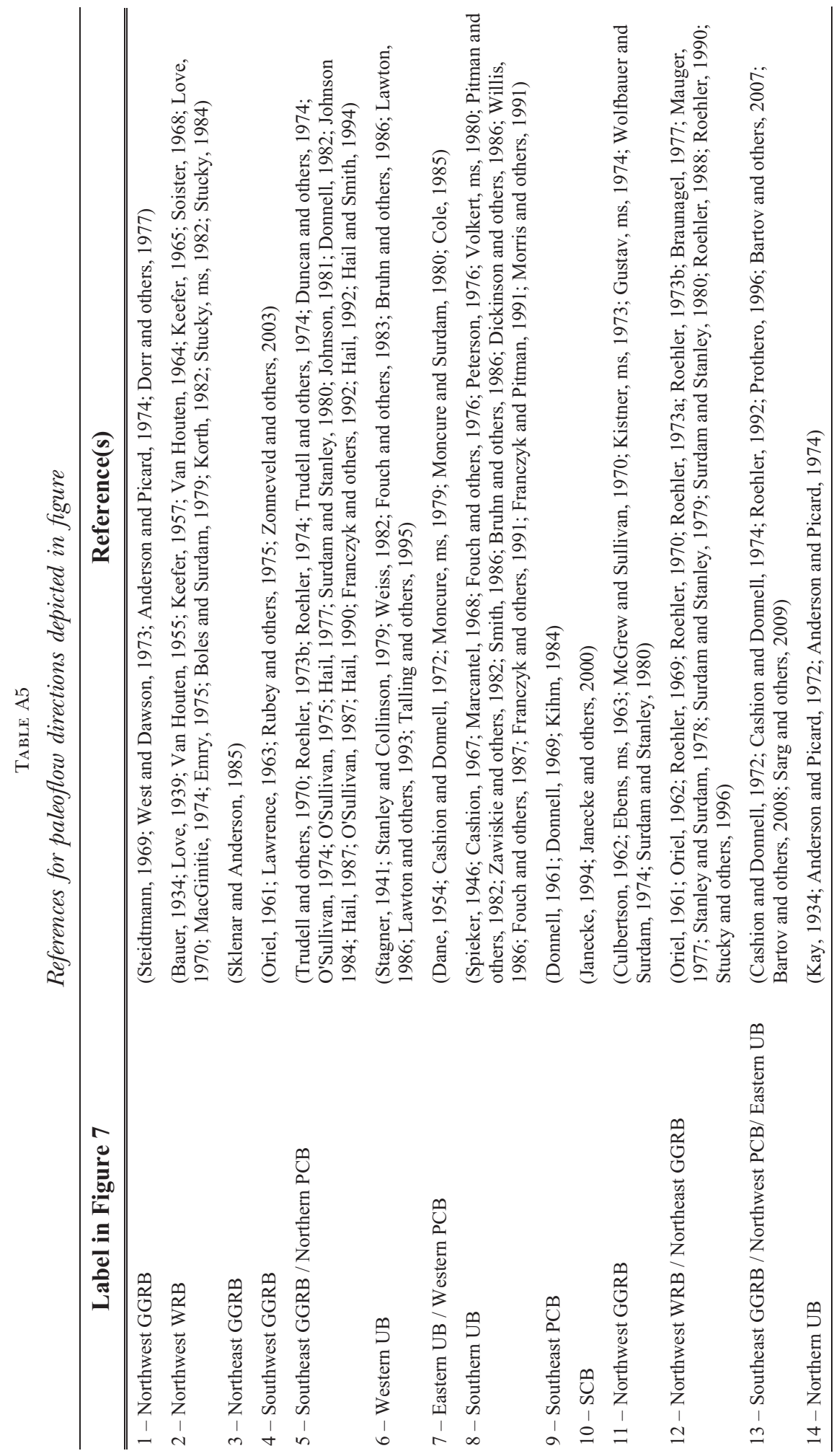


TABLE A6

References for strontium isotope ratios of exposure depicted in figure 1

\begin{tabular}{|c|c|}
\hline Location and Rock Type & Reference(s) \\
\hline \multicolumn{2}{|c|}{ Precambrian Cores of Laramide Uplifts } \\
\hline Uinta Uplift (UU) & $\begin{array}{l}\text { (Crittenden and Peterman, 1975; Bouchard and others, 1998; Gerner and } \\
\text { others, 2007) }\end{array}$ \\
\hline Wind River Uplift (WRU) & (Frost and others, 1998) \\
\hline Sierra Madre Uplift (SMU) & (Divis, 1977) \\
\hline Front Range Uplift (FRU) & (Hedge and others, 1967) \\
\hline Owl Creek Uplift (OCU) & (Mueller and others, 1985) \\
\hline Granite Uplift (GU) & (Peterman and Hildreth, 1978) \\
\hline Laramie Uplift (LU) & (Zielinski and others, 1981; Patel and others, 1999) \\
\hline Sawatch-San Luis Uplift (SSU) & (Pearson and others, 1966; Moorbath and others, 1967) \\
\hline Sangre de Cristo Uplift (SCU) & (Nelson and DePaolo, 1988) \\
\hline $\begin{array}{l}\text { Precambrain, Paleozoic and } \\
\text { Mesozoic Carbonates }\end{array}$ & (Paces and others, 2007; Bright, 2009) \\
\hline Tertiary Volcanic Provinces & $\begin{array}{l}\text { (Peterman and others, 1970; Meen and Eggler, 1987; Norman and } \\
\text { Leeman, 1989; Cunningham and others, 1998; Vogel and others, 2001) }\end{array}$ \\
\hline Absaroka & (Peterman and others, 1970; Meen and Eggler, 1987) \\
\hline Challis & (Norman and Leeman, 1989) \\
\hline Keetley & (Vogel and others, 2001) \\
\hline Marysvale & (Cunningham and others, 1998) \\
\hline
\end{tabular}

\section{REFERENCES}

Anderson, D. W., and Picard, M. D., 1972, Stratigraphy of the Duchesne River Formation (EoceneOligocene?), Northern Uinta Basin, Northeastern Utah: Utah Geological and Mineralogical Survey Bulletin, v. 97, p. 1-23.

1974, Evolution of synorogenic clastic deposits in the intermontane Uinta Basin of Utah in Dickinson, W. R., editor, Tectonics and Sedimentation: SEPM Special Publication, v. 22, p. 167-189.

Axen, G. J., Taylor, W. J., and Bartley, J. M., 1993, Space-time patterns and tectonic controls of Tertiary magmatism in the Great Basin of the western United States: Geological Society of America Bulletin, v. 105, p. 56-76, doi:10.1130/0016-7606(1993) 105〈0056:STPATC〉2.3.CO;2.

Bartov, Y., Picha, M., and Daub, J., 2007, Oil shale of the Piceance Creek and eastern Uinta Basins, 27th Oil Shale Symposium: Golden, Colorado, Colorado School of Mines.

Bartov, Y., Nummendal, D., and Sarg, R., 2008, The depositional system of the Green River oil shale in western Colorado: San Antonio, Texas, AAPG Annual Convention, Search and Discovery Article \#90078.

Bauer, C. M., 1934, Wind River Basin [Wyoming]: Geological Society of America Bulletin, v. 45, p. 665-696.

Bohacs, K. M., Carroll, A. R., Neal, J. E., and Mankiewicz, P. J., 2000, Lake-basin type, source potential, and hydrocarbon character: an integrated sequence-stratigraphic-geochemical framework, in GierlowskiKordesch, E. H., and Kelts, K. R., editors, Lake basins through space and time: AAPG Studies in Geology No. 46, p. 3-34.

Boles, J. R., and Surdam, R. C., 1979, Diagenesis of volcanogenic sediments in a Tertiary saline lake; Wagon Bed Formation, Wyoming: American Journal of Science, v. 279, p. 832-853.

Bouchard, D. P., Kaufman, D. S., Hochberg, A., and Quade, J., 1998, Quaternary history of the Thatcher Basin, Idaho, reconstructed from the ${ }^{87} \mathrm{Sr} /{ }^{86} \mathrm{Sr}$ and amino acid composition of lacustrine fossils: implications for the diversion of the Bear River into the Bonneville Basin: Palaeogeography, Palaeoclimatology, Palaeoecology, v. 141, p. 95-114, doi:10.1016/S0031-0182(98)00005-4.

Bowen, G. J., and Bowen, B. B., 2008, Mechanisms of PETM global change constrained by a new record from central Utah: Geology, v. 36, p. 379-382, doi: 10.1130/G24597A.1.

Bowen, G. J., Daniels, A. L., and Bowen, B. B., 2008, Paleoenvironmental isotope geochemistry and paragenesis of lacustrine and palustrine carbonates, Flagstaff Formation, central Utah, USA: Journal of Sedimentary Research, v. 78, p. 162-174. 
Bradley, W. H., 1931, Origin and microfossils of the oil shale of the Green River Formation of Colorado and Utah: United States Geological Survey Professional Paper, v. 168, 58 p.

Brass, G. W., 1975, The effect of weathering on the distribution of strontium isotopes in weathering profiles: Geochimica et Cosmochimica Acta, v. 39, p. 1,647-1,653, doi:10.1016/0016-7037(75)90086-1.

Braunagel, L. H., and Stanley, K. O., 1977, Origin of variegated redbeds in the Cathedral Bluffs Tongue of the Wasatch Formation (Eocene), Wyoming: Journal of Sedimentary Petrology, v. 47, p. 1,201-1,219.

Bright, J., 2009, Isotope and major-ion chemistry of groundwater in Bear Lake Valley, Utah and Idaho, with emphasis on the Bear River Range, in Rosenbaum, J. G., and Kaufman, D. S., editors, Paleoenvironments of Bear Lake, Utah and Idaho, and its catchment: Geological Society of America Special Paper 150 , p. $105-132$.

Brobst, D. A., and Tucker, J. D., 1973, X-ray mineralogy of the Parachute Creek Member, Green River Formation, in the Northern Piceance Creek Basin, Colorado: United States Geological Survey Professional Paper 803, p. 1-53.

Bruhn, R. L., Picard, M. D., and Isby, J. S., 1986, Tectonics and sedimentology of Uinta Arch, western Uinta Mountains, and Uinta Basin, in Peterson, J. A., editor, Paleotectonics and sedimentation in the Rocky Mountain region, United States: American Association of Petroleum Geologists Memoir, v. 41, p. 333352.

Carroll, A. R., and Bohacs, K. M., 1999, Stratigraphic classification of ancient lakes: Balancing tectonic and climatic controls: Geology, v. 27, p. 99-102, doi:10.1130/0091-7613(1999)027〈0099:SCOALB〉2.3.CO;2.

Carroll, A. R., Chetel, L. M., and Smith, M. E., 2006, Feast to famine: Sediment supply control on Laramide basin fill: Geology, v. 34, p. 197-200, doi:10.1130/G22148.1

Carroll, A. R., Doebbert, A. C., Booth, A. L., Chamberlain, C. P., Rhodes-Carson, M. K., Smith, M. E., Johnson, C. M., and Beard, B. L., 2008, Capture of high altitude precipitation by a low altitude Eocene lake, western U.S.: Geology, v. 36, p. 791-794, doi: 10.1130/G24783A.1.

Cashion, W. B., 1967, Geology and fuel resources of the Green River Formation Southeastern Uinta Basin Utah and Colorado: U.S. Geological Survey Professional Paper n. 548, p. 48.

Cashion, W. B., and Donnell, J. R., 1972, Chart showing correlation of selected key units in the organic-rich sequence of Green River Formation, Piceance Creek basin, Colorado, and Uinta basin, Utah: U.S. Geological Survey Oil and Gas Investigations Chart OC 65.

— 1974, Revision of Nomenclature of the Upper Part of the Green River Formation, Piceance Creek Basin, Colorado, and Eastern Uinta Basin, Utah: U.S. Geological Survey Bulletin, v. 1394-G, p. 1-9.

Chamberlain, C. P., and Poage, M. A., 2000, Reconstructing the paleotopography of mountain belts from the isotopic composition of authigenic minerals: Geology, v. 28, p.115-118, doi:10.1130/00917613(2000) 28<115:RTPOMB $>2.0 . \mathrm{CO} ; 2$.

Christensen, R. L., and Yeats, R. L., 1992, Post-Laramide geology of the U.S. Cordilleran region, in Burchfiel, B. C., Lipman, P. W., and Zoback, M. L. C., editors, The Cordilleran Orogen: Conterminous U.S.: Geology of North America: Boulder, Colorado, Geological Society of America, v. g-3, p. 261-406.

Cole, R. D., 1985, Depositional environments of oil-shale in the Green River Formation, Douglas Creek Arch, Colorado and Utah, in Picard, M. D., editor, Geology and Energy Resources, Uinta Basin of Utah: Salt Lake City, Utah Geological Association, p. 211-224.

Crittenden, M. D., Jr., and Peterman, Z. E., 1975, Provisional Rb/Sr age of the Precambrian Uinta Mountain Group, northeastern Utah: Utah Geology, v. 2, p. 75-77.

Culbertson, W. C., 1962, Laney Shale Member and Tower Sandstone Lentil of the Green River Formation, Green River Area, Wyoming: U.S. Geological Survey Professional Paper, v. 450-C, p. 54-57.

Cunningham, C. G., Unruh, D. M., Steven, T. A., Rowley, P. D., Naeser, C. W., Mehnert, H. H., Hedge, C. E., and Ludwig, K. R., 1998, Geochemistry of Volcanic Rocks in the Marysvale Volcanic Field, West-Central Utah: U.S. Geological Survey Bulletin, v. 2158, p. 223-231.

Dane, C. H., 1954, Stratigraphic and facies relationships of upper part of Green River Formation and lower part of the Uinta Formation in Duchesne, Uintah, and Wasatch counties: Bulletin of the American Association of Petroleum Geologists, v. 38, p. 405-425.

Davis, S. J., Wiegand, B. A., Carroll, A. R., and Chamberlain, C. P., 2008, The Effect of Drainage Reorganization on Paleoaltimetry Studies: An Example from the Paleogene Laramide Foreland: Earth and Planetary Science Letters, v. 275, p. 258-268, doi:10.1016/j.epsl.2008.08.009.

Davis, S. J., Mulch, A., Carroll, A. R., Horton, T. W., and Chamberlain, C. P., 2009, Paleogene landscape evolution of the central North American Cordillera: Developing topography and hydrology in the Laramide foreland: Geological Society of America Bulletin, v. 121, p. 100-116, doi: 10.1130/B26308.1.

de Villiers, S., Greaves, M., and Elderfield, H., 2002, An intensity ratio calibration method for the accurate determination of $\mathrm{Mg} / \mathrm{Ca}$ and $\mathrm{Sr} / \mathrm{Ca}$ of marine carbonates by ICP-AES: Geochemistry Geophysics Geosystems, v. 3, paper number 2001GC000169, 10.1029/2001GC000169.

DeCelles, P. G., 1988, Lithologic provenance modeling applied to the Late Cretaceous synorogenic Echo Canyon Conglomerate, Utah: A case of multiple source areas: Geology, v. 16, p. 1,039-1,043, doi:10.1130/

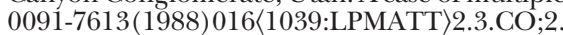

— 2004, Late Jurassic to Eocene Evolution of the Cordilleran Thrust Belt and Foreland Basin System, Western U.S.A.: American Journal of Science, v. 304, p. 105-168, doi:10.2475/ajs.304.2.105.

DeCelles, P. G., Lawton, T. F., and Mitra, G., 1995, Thrust timing, growth of structural culminations, and synorogenic sedimentation in the type Sevier orogenic belt, western United States: Geology, v. 23, p. 699-702, doi:10.1130/0091-7613(1995)023〈0699:TTGOSC)2.3.CO;2.

Dettman, D. L., and Lohmann, K. C., 2000, Oxygen isotope evidence for high-altitude snow in the Laramide Rocky Mountains of North America during the Late Cretaceous and Paleogene: Geology, v. 28, p. 243-246, doi:10.1130/0091-7613(2000) 28<243:OIEFHS〉2.0.CO;2.

Dickinson, W. R., 2004, Evolution of the North American Cordillera: Annual Review of Earth and Planetary Sciences, v. 32, p. 13-45, doi:10.1146/annurev.earth.32.101802.120257. 
Dickinson, W. R., and Gehrels, G. E., 2003, U-Pb ages of detrital zircons from Permian and Jurassic eolian sandstones of the Colorado Plateau, USA: paleogeographic implications: Sedimentary Geology, v. 163, p. 29-66, doi:10.1016/S0037-0738(03)00158-1.

Dickinson, W. R., Lawton, T. F., and Inman, K. F., 1986, Sandstone detrital modes, central Utah foreland region: stratigraphic record of Cretaceous-Paleogene tectonic evolution: Journal of Sedimentary Petrology, v. 56, p. 276-293.

Dickinson, W. R., Klute, M. A., Hayes, M. J., Janecke, S. U., Lundin, E. R., McKittrick, M. A., and Olivares, M. D., 1988, Paleogeographic and paleotectonic setting of Laramide sedimentary basins in the central Rocky Mountain region: Geological Society of America Bulletin, v. 100, p. 1,023-1,039, doi:10.1130/00167606(1988) 100<1023:PAPSOL〉2.3.CO;2.

Divis, A. F., 1977, Isotopic studies on a Precambrain geochronologic boundary, Sierra Madre Mountains, Wyoming: Geological Society of America Bulletin, v. 88, p. 96-100.

Donnell, J. R., 1961, Tripartition of the Wasatch Formation near De Beque in northwestern Colorado: U.S. Geological Survey Professional Paper, v. 424-B, p. 147-148.

_ 1969, Paleocene and Lower Eocene Units in the Southern Part of the Piceance Creek Basin Colorado in Contributions to Stratigraphy: U.S. Geological Survey Bulletin, v. 1274-M, p. M1-M18.

- 1982, Tongues of the Green River and Uinta Formations in the Piceance Creek Basin, in Gary, J. H., editor, Fifteenth Oil Shale Symposium Proceedings: Golden, Colorado, Colorado School of Mines Press, p. 29-37.

Dorr, J. A., Jr., Spearing, D. R., and Steidtmann, J. R., 1977, Deformation and deposition between a foreland uplift and an impinging thrust belt: Hoback Basin, Wyoming: Geological Society of America Special Paper, v. 177, 82 p.

Drummond, C. N., Wilinson, B. H., Lohmann, K. C., and Smith, G. R., 1993, Effect of regional topography and hydrology on the lacustrine isotopic record of Miocene paleoclimate in the Rocky Mountains: Palaeogeography, Palaeoclimatology, Palaeoecology, v. 101, p. 67-79, doi:10.1016/0031-0182(93)90152-9.

Dubiel, R. F., Potter, C. J., Good, S. C., and Snee, L. W., 1996, Reconstructing an Eocene extensional basin: the White Sage Formation, eastern Great Basin, in Beratan, K. K., editor, Reconstructing the history of Basin and Range extension using sedimentology and stratrigraphy: Geological Society of America Special Paper, v. 303, p. 1-14.

Duncan, D. C., Hail, W. J., Jr., O’Sullivan, R. B., and Pipiringos, G. N., 1974, Four Newly Named Tongues of Eocene Green River Formation, Northern Piceance Creek Basin, Colorado in Contributions to Stratigraphy: U.S. Geological Survey Bulletin, v. 1394-F, p. FF-F13.

Ebens, R. J., ms, 1963, Petrography of the Eocene Tower Sandstone lenses at Green River, Sweetwater County, Wyoming: Laramie, University of Wyoming, Masters Thesis, p. 46.

Elston, D. P., and Young, R. A., 1991, Cretaceous-Eocene (Laramide) landscape development and OligocenePliocene drainage reorganization of Transition Zone and Colorado Plateau, Arizona: Journal of Geophysical Research, v. 96(B7), p. 12,389-12,406, doi:10.1029/90JB01978.

Emry, R. J., 1975, Revised Tertiary stratigraphy and paleontology of the western Beaver Divide, Fremont County, Wyoming: Smithsonian Contributions to Paleobiology, v. 25, p. 20.

Epis, R. C., and Chapin, C. E., 1975, Geomorphic and tectonic implications of the post-Laramide, late Eocene erosion surface in the Southern Rocky Mountains, in Curtis, B. F., editor, Cenozoic history of the Southern Rocky Mountains: Geological Society of America Memoir, v. 144, p. 45-74.

Eugster, H. P., and Kelts, K., 1983, Lacustrine chemical sediments, in Goudie, A. S., and Pye, K., editors, Chemical sediments and geomorphology: precipitates and residua in the near-surface environment: San Francisco, Academic Press, p. 321-368.

Flowers, R. M., Wernicke, B. P., and Farley, K. A., 2008, Unroofing, incision, and uplift history of the southwestern Colorado Plateau from apatite (U-Th)/He thermochronometry: Geological Society of America Bulletin, v. 120, p. 571-587, doi:10.1130/B26231.1.

Foster, D. A., Mueller, P. A., Mogk, D. W., Wooden, J. L., and Vogl, J. J., 2006, Proterozoic evolution of the western margin of the Wyoming craton: implications for the tectonic and magmatic evolution of the northern Rocky Mountains: Canadian Journal of Earth Sciences, v. 43, p. 1,601-1,619, doi:10.1139/E06052 .

Fouch, T. D., 1979, Character and paleogeographic distribution of Upper Cretaceous (?) and Paleogene nonmarine sedimentary rocks in east-central Nevada, in Armentrout, J. M., Cole, M. R., and TerBest, H., editors, Cenozoic paleogeography of the western United States, Pacific Coast Paleogeography Symposium 3: Pacific Section, Society of Economic Paleontologists and Mineralogists, p. 97-111.

Fouch, T. D., Cashion, W. B., Ryder, R. T., and Campbell, J. A., 1976, Field guide to lacustrine and related nonmarine depositional environments in Tertiary rocks, Uinta basin, Utah, in Epis, R. C., and Weimer, R. J., editors, Studies in Colorado field geology: Colorado School of Mines, Professional Contributions No. 8, p. 358-385.

Fouch, T. D., Lawton, T. F., Nichols, D. J., Cashion, W. B., and Cobban, W. A., 1983, Patterns and timing of synorogenic sedimentation in Upper Cretaceous rocks of central and northeast Utah, in Reynolds, M. W., and Dolly, E. D., editors, Mesozoic paleogeography of the west-central United States: Rocky Mountain Paleogeography Symposium 2, SEPM, p. 305-328.

Fouch, T. D., Hanley, J. H., Forester, R. M., Keighin, C. W., Pitman, J. K., and Nichols, D. J., 1987, Chart showing lithology, mineralogy, and paleontology of the nonmarine North Horn Formation and Flagstaff Member of the Green River Formation, Price Canyon, central Utah: A principal reference section: U.S. Geological Survey Miscellaneous Investigations Series Map, I-1797-A, 8 p., 1 sheet.

Franczyk, K. J., and Pitman, J. K., 1991, Latest Cretaceous Nonmarine depositional systems in the Wasatch Plateau area: Reflections of foreland to intermontane basin transition, in Chidsey, T. C., editor, Geology of east-central Utah: Salt Lake City, Utah, Utah Geological Association Publication 19, p. 77-93. 
Franczyk, K. J., Hanley, J. H., Pitman, J. K., and Nichols, D. J., 1991, Paleocene depositional systems in the western Roan Cliffs, Utah, in Chidsey, T. C., editor, Geology of east-central Utah: Utah Geological Association Publication 19, p. 111-127.

Franczyk, K. J., Fouch, T. D., Johnson, R. C., Molenaar, C. M., and Cobban, W. A., 1992, Cretaceous and Tertiary paleogeographic reconstructions for the Uinta-Piceance Basin study area, Colorado and Utah: U.S. Geological Survey Bulletin, v. 1787-Q, p. 1-37.

Fricke, H. C., 2003, Investigation of early Eocene water-vapor transport and paleoelevation using oxygen isotope data from geographically widespread mammal remains: Geological Society of America Bulletin, v. 115, p. 1088-1096, doi:10.1130/B25249.1.

Fricke, H. C., Clyde, W. C., O'Neil, J. R., and Gingerich, P. D., 1998, Evidence for rapid climate change in North America during the latest Paleocene thermal maximum: oxygen isotope compositions of biogenic phosphate from the Bighorn Basin (Wyoming): Earth and Planetary Science Letters, v. 160, p. 193-208, doi:10.1016/S0012-821X(98)00088-0.

Frost, C. D., Frost, B. R., Chamberlain, K. R., and Hulsebosch, T. P., 1998, The Late Archean history of the Wyoming province as recorded by granitic magmatism in the Wind River Range, Wyoming: Precambrian Research, v. 89, p. 145-173, doi:10.1016/S0301-9268(97)00082-X.

Garzione, C. N., Dettman, D. L., Quade, J., DeCelles, P. G., and Butler, R. F., 2000, High times on the Tibetan Plateau: Paleoelevation of the Thakkola graben, Nepal: Geology, v. 28, p. 339-342, doi:10.1130/00917613(2000) 28<339:HTOTTP $>2.0 . \mathrm{CO} ; 2$.

Gehrels, G. E., Valencia, V., and Ruiz, J., 2008, Enhanced precision, accuracy, efficiency, and spatial resolution of $\mathrm{U}-\mathrm{Pb}$ ages by laser ablation-multicollector- inductively coupled plasma-mass spectrometry: Geochemistry Geophysics Geosystems, v. 9, p. Q03017, doi:10.1029/2007GC001805.

Gerner, S. J., Spangler, L. E., Kimball, B. A., and Naftz, D. L., 2007, Characterization of dissolved solids in water resources of agricultural lands near Manila, Utah, 2004-05: U.S. Geological Survey, Scientific Investigations Report 2006-5211, p. 45.

Gierlowski-Kordesch, E. H., Jacobson, A. D., Blum, J. D., and Valero-Garcés, B. L., 2008, Watershed reconstruction of a Paleocene-Eocene lake basin using $\mathrm{Sr}$ isotopes in carbonate rocks: Geological Society of America Bulletin, v. 120, p. 85-95, doi:10.1130/B26070.1.

Goldstrand, P. M., 1994, Tectonic development of Upper Cretaceous to Eocene strata of southwestern Utah: Geological Society of America Bulletin, v. 106, p. 145-154, doi:10.1130/0016-7606(1994)106<0145: TDOUCT) 2.3.CO;2.

Good, S. C., 1987, Mollusc-based interpretations of lacustrine paleoenvironments of the Sheep Pass Formation (Latest Cretaceous to Eocene) of east central Nevada: PALOIS, v. 2, p. 467-478.

Graham, S. A., Chamberlain, C. P., Yue, Y., Ritts, B. D., Hanson, A. D., Horton, T. W., Waldbauer, J. R., Poage, M. A., and Feng, X., 2005, Stable isotope records of Cenozoic climate and topography, Tibetan Plateau and Tarim Basin: American Journal of Science, v. 305, p. 101-118, doi:10.2475/ajs.305.2.101.

Gustav, S. H., ms, 1974, The sedimentology and paleogeography of the Bridger Formation, (Eocene) of southwestern Wyoming: Boston, University of Massachusetts, p. 82.

Hail, W. J., Jr., 1977, Stewart Gulch Tongue-A New Tongue of the Eocene Green River Formation, Piceance Creek Basin, Colorado, in Contributions to Stratigraphy: U.S. Geological Survey Bulletin, v. 1422-E, p. $1-8$.

1987, Chart showing intertongued units of the Eocene Green River and Uinta Formations, Northwestern Piceance Creek Basin, Northwestern Colorado: U.S. Geological Survey, Miscellaneous Investigations Series, Map I-1797-B.

1990, Geology of the Lower Yellow Creek Area, Northwestern Colorado: U.S. Geological Survey Bulletin, v. 1787-O, p. 1-45.

1992, Geology of the Central Roan Plateau Area, Northwestern Colorado: U.S. Geological Survey Bulletin, v. 1787-R, p. 1-26.

Hail, W. J., Jr., and Smith, M. C., 1994, Geologic map of the northern part of the Piceance Creek basin, northwestern Colorado: U.S. Geological Survey, Miscellaneous Investigations Series, map-I-2400.

Hansen, W. R., 1965, Geology of the Flaming Gorge area, Utah-Colorado-Wyoming: U.S. Geological Survey Professional Paper, v. 400-B, p. 260-261.

_ 1985, Drainage development of the Green River Basin in southwestern Wyoming and its bearing on fish biogeography, neotectonics, and paleoclimates: Mountain Geologist, v. 22, p. 192-204.

Hart, W. S., Quade, J., Madsen, D. B., Kaufman, D. S., and Oviatt, C. G., 2004, The ${ }^{87} \mathrm{Sr} /{ }^{86} \mathrm{Sr}$ ratios of lacustrine carbonates and lake-level history of the Bonneville paleolake system: Geological Society of America Bulletin, v. 116, p. 1,107-1,119, doi: 10.1130/B25330.1.

Hayden, F. V., 1869, Preliminary field report of the United States Geological Survey of Colorado and New Mexico: U.S. Geological Survey of the Territories, v. Third Annual Report, 155 p.

Hedge, C. E., Peterman, Z. E., and Braddock, W. A., 1967, Age of the major Precambrian regional metamorphism in the northern Front Range, Colorado: Geological Society of America Bulletin, v. 78, p. 551-558, doi: 10.1130/0016-7606(1967)78[551:AOTMPR]2.0.CO;2.

Henry, C. D., 2008, Ash-flow tuffs and paleovalleys in northeastern Nevada: Implications for Eocene paleogeography and extension in the Sevier hinterland, northern Great Basin: Geosphere, v. 4, p. 1-35, doi:10.1130/GES00122.1/.

Horton, T. W., Sjostrom, D. J., Abruzzese, M. J., Poage, M. A., Waldbauer, J. R., Hren, M., Wooden, J., and Chamberlain, C. P., 2004, Spatial and temporal variation of Cenozoic surface elevation in the Great Basin and Sierra Nevada: American Journal of Science, v. 304, p. 862-888, doi:10.2475/ajs.304.10.862.

Ingersoll, R. V., Cavazza, W., Baldridge, W. S., and Shafiqullah, M., 1990, Cenozoic sedimentation and paleotectonics of north-central New Mexico: Implications for initiation and evolution of the Rio Grande rift: Geological Society of America Bulletin, v. 102, p. 1,280-1,296, doi:10.1130/00167606(1990) 102〈1280:CSAPON $>2.3 . C O ; 2$. 
Jacobsen, A. D., and Blum, J. D., 2000, Ca/Sr and ${ }^{87} \mathrm{Sr} /{ }^{86} \mathrm{Sr}$ geochemistry of disseminated calcite in Himalayan silicate rocks from Nanga Parbat: Influence on river-water chemistry: Geology, v. 28, p. 463-466, doi:10.1130/0091-7613(2000)28〈463:SASGOD〉2.0.CO;2.

Janecke, S. U., 1994, Sedimentation and paleogeography of an Eocene to Oligocene rift zone, Idaho and Montana: Geological Society of America Bulletin, v. 106, p. 1,083-1,095, doi: 10.1130/00167606(1994) 106<1083:SAPOAE $>2.3 . C O ; 2$.

Janecke, S. U., VanDenburg, C. J., Blankenau, J. J., and M'Gonigle, J. W., 2000, Long-distance longitudinal transport of gravel across the Cordilleran thrust belt of Montana and Idaho: Geology, v. 28, p. 439-442, doi:10.1130/0091-7613(2000)28〈439:LLTOGA〉2.0.CO;2.

Johnson, R. C., 1981, Stratigraphic evidence for a deep Eocene Lake Uinta, Piceance Creek Basin, Colorado: Geology, v. 9, p. 55-62, doi: 10.1130/0091-7613(1981)9/55:SEFADE)2.0.CO;2.

- 1984, New Names for Units in the Lower Part of the Green River Formation, Piceance Creek Basin, Colorado: U.S. Geological Survey Bulletin, v. 1529-I, p. 1-20.

Jones, L. M., and Faure, G., 1972, Strontium isotope geochemistry of Great Salt Lake, Utah: Geological Society of America Bulletin, v. 83, p. 1,875-1,880, doi:10.1130/0016-7606(1972)83[1875:SIGOGS]2.0.CO;2.

Kay, J. L., 1934, The Tertiary formations of the Uinta Basin, Utah: Annals of the Carnegie Museum, v. 23, p. 357-371.

Keefer, W. R., 1957, Geology of the Du Noir area Fremont County Wyoming: U.S. Geological Survey Professional Paper, v. 294-E, p. 155-221.

- 1965, Stratigraphy and geologic history of the uppermost Cretaceous, Paleocene, and Lower Eocene rocks in the Wind River Basin, Wyoming: U.S. Geological Survey Professional Paper, v. 495-A, p. 77.

Kelts, K., 1988, Environments of deposition of lacustrine petroleum source rocks: an introduction, in Fleet, A. J., Kelts, K., and Talbot, M. R., editors, Lacustrine Petroleum Source Rocks: London, Geological Society Special Publication, v. 40, p. 3-26.

Kent-Corson, M. L., Sherman, L. S., Mulch, A., and Chamberlain, C. P., 2006, Cenozoic topographic and climatic response to changing tectonic boundary conditions in Western North America: Earth and Planetary Science Letters, v. 252, p. 453-466, doi:10.1016/j.epsl.2006.09.049.

Kihm, A. J., ms, 1984, Early Eocene Mammalian Faunas of the Piceance Creek Basin Northwestern Colorado: Boulder, Colorado, University of Colorado at Boulder, Ph. D. thesis, p. 390.

Kistner, F. B., ms, 1973, Stratigraphy of the Bridger Formation in the Big Island-Blue Rim area, Sweetwater County, Wyoming: Laramie, University of Wyoming, Master's thesis, p. 174.

Koch, P. L., Zachos, J. C., and Dettman, D. L., 1995, Stable isotope stratigraphy and paleoclimatology of the Paleogene Bighorn Basin (Wyoming, USA): Palaeogeography, Palaeoclimatology, Palaeoecology, v. 115, p. 61-89, doi:10.1016/0031-0182(94)00107-J.

Korth, W. W., 1982, Revision of the Wind River faunas, early Eocene of central Wyoming. Part 2. Geologic setting: Annals of the Carnegie Museum, v. 51, p. 57-78.

Lawrence, J. C., 1963, Origin of the Wasatch Formation, Cumberland Gap area, Wyoming: University of Wyoming Contributions to Geology (Rocky Mountain Geology), v. 2, p. 151-158.

Lawton, T. F., 1986, Fluvial systems of the Upper Cretaceous Mesaverde Group and Paleocene North Horn Formation, central Utah: A record of transition from thin-skinned to thick-skinned deformation in the foreland region, in Peterson, J. A., editor, Paleotectonics and Sedimentation in the Rocky Mountain Region, United States: American Association of Petroleum Geologists Memoir, v. 41, p. 423-442.

Lawton, T. F., Talling, P. J., Hobbs, R. S., Trexler, J. H., Jr., Weiss, M. P., and Burbank, D. W., 1993, Structure and Stratigraphy of Upper Cretaceous and Paleocene Strata (North Horn Formation), Eastern San Pitch Mountains, Utah-Sedimentation at the Front of the Sevier Orogenic Belt, in Evolution of Sedimentary Basins; Uinta and Piceance basins: U.S. Geological Survey Bulletin B 1787-II, p. 1-36.

Lipman, P. W., Prostka, H. J., and Christensen, R. L., 1972, Cenozoic volcansim and plate tectonic evolution of the western United States. I. Early and Middle Cenozoic: Philosophical Transactions of the Royal Society of London, Series A, Mathematical and Physical Sciences, v. 271, p. 217-248.

Love, J. D., 1939, Geology along the southern margin of the Absaroka Range, Wyoming: Geological Society of America Special Paper, v. 20, 134 p.

- 1970, Cenozoic geology of the Granite Mountains area, central Wyoming: U.S. Geological Survey Professional Paper, v. 495-C, p. 154.

Ludwig, K. R., 2001, SQUID 1.02; a users manual: Berkeley, California, Berkeley Geochronology Center Special Publication n. 2.

MacGinitie, H. D., 1974, An early middle Eocene flora from the Yellowstone-Absaroka Volcanic Province, northwestern Wind River Basin, Wyoming: Berkeley, California, University of California Publications in Geological Sciences, v. 108, 103 p.

Marcantel, E. L., and Weiss, M. P., 1968, Colton Formation (Eocene: Fluviatile) and associated lacustrine beds, Gunnison Plateau, central Utah: The Ohio Journal of Science, v. 68, p. 40-49.

Mauger, R. L., 1977, K-Ar ages of biotites from tuffs in Eocene rocks of the Green River, Washakie, and Uinta basins, Utah, Wyoming, and Colorado: University of Wyoming Contributions to Geology (Rocky Mountain Geology), v. 15, p. 17-41.

McCrea, J. M., 1950, On the isotopic chemistry of carbonates and a paleotemperature scale: The Journal of Chemical Physics, v. 18, p. 849-857, doi:10.1063/1.1747785.

McGrew, P. O., and Sullivan, R., 1970, The stratigraphy and paleontology of Bridger A: University of Wyoming, Contributions to Geology, v. 9, p. 66-85.

McMillan, M. E., Heller, P. L., and Wing, S. L., 2006, History and causes of post-Laramide relief in the Rocky Mountain orogenic plateau: Geological Society of America Bulletin, v. 118, p. 393-405, doi:10.1130/ B25712.1. 
Meen, J. K., and Eggler, D. H., 1987, Petrology and geochemistry of the Cretaceous Independence volcanic suite, Absaroka Mountains, Montana: Clues to the composition of the Archean sub-Montana mantle: Geological Society of America Bulletin, v. 98, p. 238-247, doi: 10.1130/0016-7606(1987)98<238: PAGOTC)2.0.CO;2.

Moncure, G. K., ms, 1979, Depositional environment of the Green River Formation in the vicinity of the Douglas Creek Arch, Colorado and Utah: Laramie, University of Wyoming, Master's thesis, p. 55.

Moncure, G., and Surdam, R. C., 1980, Depositional environment of the Green River Formation in the vicinity of the Douglas Creek Arch, Colorado and Utah: University of Wyoming Contributions to Geology, v. 19, p. 9-24.

Moorbath, S., Hurley, P. M., and Fairbairn, H. W., 1967, Evidence for the origin and age of some mineralized Laramide intrusives in the southwestern United States from strontium isotope and rubidium-strontium measurements: Economic Geology, v. 62, p. 228-236, doi: 10.2113/gsecongeo.62.2.228.

Morrill, C., and Koch, P. L., 2002, Elevation or alteration? Evaluation of isotopic constraints on paleoaltitudes surrounding the Eocene Green River Basin: Geology, v. 30, p. 151-154, doi:10.1130/00917613(2002)030<0151:EOAEOI $>2.0 . \mathrm{CO} ; 2$.

Morris, T. H., Richmond, D. R., and Marino, J. E., 1991, The Paleocene/Eocene Colton Formation: A Fluvial-dominated lacustrine deltaic system, Roan Cliffs, Utah, in Chidsey, T. C., Jr., editor, Geology of east-central Utah: Utah Geological Association Publication, v. 19, p. 129-139.

Mueller, P. A., Peterman, Z. E., and Granath, J. W., 1985, A bimodal Archean volcanic series, Owl Creek Mountains, Wyoming: Journal of Geology, v. 93, p. 701-712.

Müller, G., Irion, G., and Forstner, U., 1972, Formation and diagenesis of inorganic Ca-Mg carbonates in the lacustrine environment: Naturwissenchaften, v. 59, p. 158-164, doi:10.1007/BF00637354.

Nelson, B. K., and DePaolo, D. J., 1988, Comparison of isotopic and petrographic provenance indicators in sediments from Tertiary continental basins of New Mexico: Journal of Sedimentary Petrology (Journal of Sedimentary Research), v. 58, p. 348-357.

Nelson, S. T., Wood, M. J., Mayo, A. L., Tingey, D. G., and Eggett, D., 2005, Shoreline tufa and tufaglomerate from Pleistocene Lake Bonneville, Utah, USA: stable isotopic and mineralogical records of lake conditions, processes, and climate: Journal of Quaternary Science, v. 20, p. 3-19, doi:10.1002/jqs.889.

Norris, R. D., Jones, L. S., Corfield, R. M., and Cartlidge, J. E., 1996, Skiing in the Eocene Uinta Mountains? Isotopic evidence in the Green River Formation for snow melt and large mountains: Geology, v. 24, p. 403-406, doi:10.1130/0091-7613(1996)024〈0403:SITEUM〉2.3.CO;2.

Norman, M. D., and Leeman, W. P., 1989, Geochemical evolution of Cenozoic-Cretaceous magmatism and its relation to tectonic setting, southwestern Idaho, U.S.A.: Earth and Planetary Science Letters, v. 94, p. 78-96, doi:10.1016/0012-821X(89)90085-X.

O'Sullivan, R. B., 1974, Chart showing correlation of selected restored stratigraphic diagram units of the Eocene Uinta and Green River Formations, east-central Piceance Creek Basin, northwestern Colorado: U.S. Geological Survey Oil and Gas Investigations Chart, Report \# 67, p. 1.

_ 1975, Coughs Creek Tongue-A New Tongue of the Eocene green River Formation, Piceance Creek Basin, Colorado: U.S. Geological Survey Bulletin, v. 1395-G, p. G1-G7.

1987, Chart showing the correlation of selected parts of the Eocene Uinta and Green River Formations, southeastern Piceance Creek Basin, Colorado: U.S. Geological Survey Miscellaneous Field Studies Map, MF-1986.

Oriel, S. S., 1961, Tongues of the Wasatch and Green River Formations, Fort Hill area, Wyoming: U.S. Geological Survey Professional Paper, v. 424-B, p. B151-B152.

_ 1962, Main body of the Wasatch Formation near La Barge, Wyoming: American Association of Petroleum Geologists Bulletin, v. 46, p. 2,161-2,173.

Oviatt, C. G., 1988, Late Pleistocene and Holocene lake fluctuations in the Sevier Lake Basin, Utah, USA: Journal of Paleolimnology, v. 1, p. 9-21, doi:10.1007/BF00202190.

Oviatt, C. G., Habiger, G. D., and Hay, J. E., 1994, Variation in the composition of Lake Bonneville marl: a potential key to lake-level fluctuations and paleoclimate: Journal of Paleolimnology, v. 11, p. 19-30, doi:10.1007/BF00683268.

Paces, J. B., Peterman, Z. E., Futa, K., Oliver, T. A., and Marshall, B. D., 2007, Strontium isotopic composition of Paleozoic carbonate rocks in the Nevada Test Site vicinity, Clark, Lincoln, and Nye Counties, Nevada, and Inyo County, California: U.S. Department of Interior, U.S. Geological Survey, Data Series 280.

Palmer, M. R., and Edmond, J. M., 1992, Controls over the strontium isotope composition of river water: Geochimica et Cosmochimica Acta, v. 56, p. 2,099-2,111, doi:10.1016/0016-7037(92)90332-D.

Patel, S. C., Frost, C. D., and Frost, B. R., 1999, Contrasting responses of Rb-Sr systematics to regional and contact metamorphism, Laramie Mountains, Wyoming, USA: Journal of Metamorphic Geology, v. 17, p. 259-269, doi: 10.1046/j.1525-1314.1999.00411.x.

Pearson, R. C., Hedge, C. E., Thomas, H. H., and Stern, T. W., 1966, Geochronology of the St. Kevin Granite and neighboring Precambrian rocks, northern Sawatch Range, Colorado: Geological Society of America Bulletin, v. 77, p. 1,109-1,120.

Peterman, Z. E., and Hildreth, R. A., 1978, Reconnaissance geology and geochronology of the Precambrian of the Granite Mountains, Wyoming: U.S. Geological Survey Professional Paper 1055, p. 22.

Peterman, Z. E., Doe, B. R., and Prostka, H. J., 1970, Lead and Strontium Isotopes in Rocks of the Absaroka Volcanic Field, Wyoming: Contributions to Mineralogy and Petrology, v. 27, p. 121-130, doi:10.1007/ BF00371979.

Peterson, A. R., 1976, Paleoenvironments of the Colton Formation, Colton, Utah: Brigham Young University Geology Studies, v. 23, p. 7-35.

Pipiringos, G. N., and Johnson, R. C., 1975, Preliminary geologic map of the Buckskin Point Quadrangle, Rio Blanco County, Colorado: U.S. Geological Survey Miscellaneous Field Studies Map 651. 
Pitman, J. K., Fouch, T. D., and Goldhaber, M. B., 1982, Depositional setting and diagenetic evolution of some Tertiary unconventional reservoir rocks, Uinta Basin, Utah: American Association of Petroleum Geologists Bulletin, v. 66, p. 1,581-1,596.

Potter, C. J., Dubiel, R. F., Snee, L. W., and Good, S. C., 1995, Eocene extension of early Eocene lacustrine strata in a complexly deformed Sevier-Laramide hinterland, northwest Utah and northeast Nevada: Geology, v. 23, p. 181-184, doi:10.1130/0091-7613(1995)023〈0181:EEOEEL〉2.3.CO;2.

Prothero, D. R., 1990, Magnetostratigraphy and ${ }^{40} \mathrm{Ar} /{ }^{39} \mathrm{Ar}$ dating of the Middle Eocene Uinta Formation, Uinta Basin, Utah: GSA Abstracts with Programs.

- 1996, Magnetic stratigraphy and biostratigraphy of the Middle Eocene Uinta Formation, Uinta Basin, Utah, in Prothero, D. R., and Emry, R. J., editors, The Terrestrial Eocene-Oligocene Transition in North America: Cambridge, Cambridge University Press, p. 3-24.

Quade, J., Roe, L., DeCelles, P. G., and Ojha, T. P., 1997, The Late Neogene ${ }^{87} \mathrm{Sr} /{ }^{86} \mathrm{Sr}$ record of lowland Himalayan rivers: Science, v. 276, p. 1,828-1,831.

Rhodes, M. K., Carroll, A. R., Pietras, J. T., Beard, B. L., and Johnson, C. M., 2002, Strontium isotope record of paleohydrology and continental weathering, Eocene Green River Formation, Wyoming: Geology, v. 30, p. 167-170, doi:10.1130/0091-7613(2002)030<0167:SIROPA $>2.0 . C O ; 2$.

Roehler, H. W., 1969, Stratigraphy and oil-shale deposits of Eocene rocks in the Washakie Basin, Wyoming, in Barlow, J. A., editor, Symposium on Tertiary Rocks of Wyoming: Casper, Wyoming, Wyoming Geological Association Field Conference Guidebook, n. 21, p. 197-206.

1970, Non-opaque heavy minerals from sandstone of Eocene age in the Washakie Basin, Wyoming: U.S. Geological Survey Professional Paper, v. 700-D, p. D181-D187.

1973a, Stratigraphic divisions and geologic history of the Laney member of the Green River Formation in the Washakie Basin in southwestern Wyoming: U.S. Geological Survey Bulletin, v. 1372-E, p. 28.

1973b, Stratigraphy of the Washakie Formation in the Washakie Basin, Wyoming: U.S. Geological Survey Bulletin, v. 1369, p. 40.

1974, Depositional environments of rocks in the Piceance Creek basin, Colorado, in Murray, D. K., editor, Energy Resources of the Piceance Creek Basin, Colorado: Denver, Colorado, Rocky Mountain Association of Geologists, p. 57-64.

1988, Geology of the Cottonwood Creek Delta in the Eocene Tipton Tongue of the Green River Formation, southeast Washakie Basin, Wyoming, in Roehler, H. W., Hanley, J. H., and Honey, J. G., editors, Geology and paleoecology of the Cottonwood Creek delta in the Eocene Tipton Tongue of the Green River Formation and a mammalian fauna from the Eocene Cathedral Bluffs Tongue of the Wasatch Formation, Southeast Washakie Basin, Wyoming: U.S. Geological Survey Bulletin, v. 1669-A-C, p. 14.

1990, Sedimentology of freshwater lacustrine shorelines in the Eocene Scheggs Bed of the Tipton Tongue of the Green River Formation, Sand Wash Basin, northwest Colorado: U.S. Geological Survey Bulletin, v. 1911, 12 p.

- 1992, Correlation, composition, areal distribution and thickness of Eocene stratigraphic units, Greater Green River Basin, Wyoming, Utah and Colorado: U.S. Geological Survey Professional Paper, v. 1506-E, p. 1-49.

1993, Eocene climates, depositional environments, and geography, greater Green River basin, Wyoming, Utah, and Colorado: U.S. Geological Survey Professional Paper, v. 1506-F, p. 74 p.

Rubey, W. W., Oriel, S. S., and Tracey, J. I., Jr., 1975, Geology of the Sage and Kemmerer 15-minute quadrangles, Lincoln County, Wyoming: U.S. Geological Survey Professional Paper, v. 855, 18 p.

Sarg, R., Bartov, Y., Carroll, A. R., and Lowenstein, T. K., 2009, The stratigraphy and depositional systems of the Green River oil shale in the Piceance Creek and Greater Green River basins, Colorado and Wyoming, AAPG Annual Convention and Exhibition, Denver, Colorado, June 7-10, 2009: Search and Discovery: Denver, Colorado, American Association of Petroleum Geologists Search and Discovery Article \#90090.

Sheldon, N. D., and Retallack, G. J., 2004, Regional paleoprecipitation records from the Late Eocene and Oligocene of North America: The Journal of Geology, v. 112, p. 487-494, doi:10.1086/421076.

Sklenar, S. E., and Anderson, D. W., 1985, Origin and early evolution of an Eocene lake system within the Washakie Basin of southwestern Wyoming, in Flores, R. M., and Kaplan, S. S., editors, Cenozoic paleogeography of the west central United States: Denver, Colorado, Society of Economic Paleontologists and Mineralogists, p. 231-245.

Smith, J. D., 1986, Depositional environments of the Tertiary Colton and basal Green River Formations in Emma Park, Utah: Brigham Young University Geology Studies, v. 33, p. 135-174.

Smith, M. E., Carroll, A. R., and Singer, B. S., 2008a, Synoptic reconstruction of a major ancient lake system: Eocene Green River Formation, western United States: Geological Society of America Bulletin, v. 120, p. 54-84, doi:10.1130/B26073.1.

Smith, M. E., Carroll, A. R., and Mueller, E. R., 2008b, Elevated weathering rates in the Rocky Mountains during the Early Eocene Climatic Optimum: Nature Geoscience, v. 1, p. 370-374, doi:10.1038/ ngeo205.

Soister, P. E., 1968, Stratigraphy of the Wind River Formation in south-central Wind River Basin, Wyoming: U.S. Geological Survey Professional Paper, v. 594-A, 50 p.

Spencer, R. J., Baedecker, M. J., Eugster, H. P., Forester, R. M., Goldhaber, M. B., Jones, B. F., Kelts, K., Mckenzie, J., Madsen, D. B., Rettig, S. L., Rubin, M., and Bowser, C. J., 1984, Great Salt Lake, and precursors, Utah: the last 30,000 years: Contributions to Mineralogy and Petrology, v. 86, p. 321-334, doi:10.1007/BF01187137.

Spieker, E. M., 1946, Late Mesozoic and early Cenozoic history of central Utah: U.S. Geological Survey Professional Paper, v. 205-D, p. 117-161. 
Stagner, W. L., 1941, The paleogeography of the eastern part of the Uinta Basin during Uinta B (Eocene) time: Annals of Carnegie Museum, v. 28, p. 273-308.

Stanley, K. O., and Collinson, J. W., 1979, Depositional history of Paleocene-lower Eocene Flagstaff Limestone and Coeval Rocks, Central Utah: American Association of Petroleum Geologists Bulletin, v. 63 , p. $311-323$.

Stanley, K. O., and Surdam, R. C., 1978, Sedimentation on the front of Eocene Gilbert-type deltas, Washakie Basin, Wyoming: Journal of Sedimentary Petrology, v. 48, p. 557-573.

Steidtmann, J. R., 1969, Stratigraphy of the Eocene Pass Peak Formation, central-western Wyoming, in Barlow, J. A., editor, Symposium on Tertiary rocks of Wyoming: Casper, Wyoming Geological Association, 21st Annual Field Conference Guidebook, p. 55-63.

Stucky, R. K., ms, 1982, Mammalian fauna and biostratigraphy of the upper part of the Wind River Formation (early to middle Eocene), Natrona County, Wyoming, and the Wasatchian-Bridgerian Boundary: Boulder, University of Colorado, Ph. D. thesis, p. 285.

- 1984, Revision of the Wind River faunas, early Eocene of central Wyoming. Part 5. Geology and biostratigraphy of the upper part of the Wind River Formation, northeastern Wind River Basin: Annals of Carnegie Museum, v. 53, p. 231-294.

Stucky, R. K., Prothero, D. R., Lohr, W. G., and Snyder, J. R., 1996, Magnetic stratigraphy, sedimentology, and mammalian faunas of the early Uintan Washakie Formation, Sand Wash Basin, Northwestern Colorado, in Prothero, D. R., and Emry, R. J., editors, The Terrestrial Eocene-Oligocene Transition in North America: Cambridge, Cambridge University Press, p. 40-51.

Surdam, R. C., and Stanley, K. O., 1979, Lacustrine sedimentation during the culminating phase of Eocene Lake Gosiute, Wyoming (Green River Formation): Geological Socieity of American Bulletin, v. 90, p. $93-110$.

_ 1980, Effects of changes in drainage-basin boundaries on sedimentation in Eocene Lakes Gosiute and Uinta of Wyoming, Utah, and Colorado: Geology, v. 8, p. 135-139, doi:10.1130/0091-7613(1980)8<135: EOCIDB $>2.0 . \mathrm{CO} ; 2$.

Talbot, M. R., 1990, A review of the paleohydrological interpretation of carbon and oxygen isotopic ratios in primary lacustrine carbonates: Chemical Geology: Isotope Geoscience Section, v. 80, p. 261-279.

Talbot, M. R., and Kelts, K., 1990, Paleolimnological signatures from carbon and oxygen isotopic ratios in carbonates from organic carbon-rich lacustrine sediments, in Katz, B., editor, Lacustrine Basin Exploration: Case Studies and Modern Analogs: American Association of Petroleum Geologists Memoir, v. 50, p. 99-112.

Talling, P. J., Lawton, T. F., Burbank, D. W., and Hobbs, R. S., 1995, Evolution of latest Cretaceous-Eocene nonmarine deposystems in the Axhandle piggyback basin of central Utah: Geological Society of America Bulletin, v. 107, p. 297-315.

Trudell, L. G., Beard, T. N., and Smith, J. W., 1970, Green River Formation lithology and oil-shale correlations in the Piceance Creek Basin, Colorado: U.S. Bureau of Mines Report of Investigations, v. $7357,226 \mathrm{p}$.

- 1974, Stratigraphic framework of Green River Formation oil shales in the Piceance Creek Basin, Colorado, in Murray, D. K., editor, Guidebook to the Energy Resources of the Piceance Creek Basin, Colorado: Denver, Colorado, Rocky Mountain Association of Geologists, 25th Annual Field Conference, p. 65-69.

Van Houten, F. B., 1955, Volcanic-rich middle and upper Eocene sedimentary rocks northwest of Rattlesnake Hills, central Wyoming: U.S. Geological Survey Professional Paper, v. 274-A., 14 p.

- 1964, Tertiary geology of the Beaver Rim area, Fremont and Natrona counties, Wyoming: U.S. Geological Survey Bulletin, v. 1164, 99 p.

Vogel, T. A., Cambray, F. W., and Constenius, K. N., 2001, Origin and emplacement of igneous rocks in the central Wasatch Mountains, Utah: Rocky Mountain Geology, v. 36, p. 119, doi: 10.2113/gsrocky.36.2.119.

Volkert, D. G., ms, 1980, Stratigraphy and petrology of the Colton Formation (Eocene), Gunnison Plateau, central Utah: DeKalb, Illinois, Northern Illinois University, Master's thesis, p. 132.

Weber, J. N., 1964, Carbon-oxygen isotopic composition of Flagstaff carbonate rocks and its bearing on the history of Paleocene-Eocene Lake Flagstaff of central Utah: Geochimica et Cosmochimica Acta, v. 28, p. 1,219-1,242, doi:10.1016/0016-7037(64)90125-5.

Weiss, M. P., 1982, Relation of the Crazy Hollow Formation to the Green River Formation, Central Utah, Overthrust Belt of Utah: Utah Geological Association Publication 10, p. 285-289.

West, R. M., and Dawson, M. R., 1973, Fossil mammals from the upper part of the Cathedral Bluffs Tongue of the Wasatch Formation (Early Bridgerian), northern Green River Basin, Wyoming: University of Wyoming Contributions to Geology, v. 12, p. 33-41.

Willis, G. C., 1986, Geologic Map of the Salina Quadrangle, Sevier County, Utah: Utah Geological and Mineral Survey Map, M-83, 20 p. 1 sheet, scale 1:24,000.

Winfrey, W. M., 1960, Stratigraphy, correlation, and oil potential of the Sheep Pass Formation, east-central Nevada, in Boettcher, J. W., and Sloan, W. W., editors, Guidebook to the Geology of east central Nevada: Intermountain Association of Petroleum Geologists, 11th annual Field Conference, Guidebook, p. 126 133.

Wingate, F. H., 1983, Palynology and age of the Elko Formation (Eocene) near Elko, Nevada: Palynology, v. 7, p. 93-132.

Wolfbauer, C. A., and Surdam, R. C., 1974, Origin of nonmarine dolomite in Eocene Lake Gosiute, Green River Basin, Wyoming: GSA Bulletin, v. 85, p. 1,733-1,740, doi: 10.1130/0016-7606(1974)85<1733: OONDIE $>2.0 . \mathrm{CO} ; 2$.

Wolfe, J. A., 1994, Tertiary climatic changes at middle latitudes of western North America: Palaeogeography, Palaeoclimatology, Palaeoecology, v. 108, p. 195-205, doi:10.1016/0031-0182(94)90233-X. 
Zachos, J., Pagani, M., Sloan, L., Thomas, E., and Billups, K., 2001, Trends, rhythms, and aberrations in global climate 65 Ma to Present: Science, v. 292, p. 686-693, doi:10.1126/science.1059412.

Zawiskie, J., Chapman, D., and Alley, R., 1982, Depositional history of the Paleocene-Eocene Colton Formation, north-central Utah, in Nielson, D. L., editor, Overthrust Belt of Utah: Utah Geological Association Publication 10, p. 273-284.

Zielinski, R. A., Peterman, Z. E., Stuckless, J. S., Rosholt, J. N., and Nkomo, I. T., 1981, The chemical and isotopic record of rock-water interaction in the Sherman Granite, Wyoming and Colorado: Contributions to Mineralogy and Petrology, v. 78, p. 209-219, doi:10.1007/BF00398915.

Zonneveld, J.-P., Bartels, W. S., and Clyde, W. C., 2003, Stratal architecture of an Early Eocene fluviallacustrine depositional system, Little Muddy Creek area, southwestern Green River Basin, Wyoming, in Raynolds, R. G., and Flores, R. M., editors, Cenozoic Systems of the Rocky Mountain Region: Denver, Rocky Mountain Section, RMS-SEPM (Society for Sedimentary Geology) Special Publication, p. 253288. 